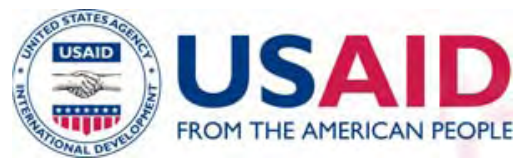

Working Paper Series on the Transition Countries

No. 2

\title{
EDUCATION \\ IN EASTERN EUROPE AND EURASIA
}

\author{
Robyn Murphy \\ Matt Petric \\ and \\ Ron Sprout
}

October 2005

Program Office

Bureau for Europe \& Eurasia

U.S. Agency for International Development 


\title{
Education in Eastern Europe and Eurasia
}

\author{
Robyn Murphy \\ U.S. Agency for International Development, Washington DC \\ Email: rmurphy@usaid.gov \\ Matt Petric \\ U.S. Agency for International Development, Washington DC \\ Email: matt.petric@gmail.com \\ Ron Sprout \\ U.S. Agency for International Development, Washington DC \\ Email: rsprout@usaid.gov
}

Abstract: Conventional wisdom has been that educational aspects of human capital in the former Communist countries were largely an asset going into the transition. However, it has also been widely perceived that the type of education in the Communist countries (with emphases on memorization at the expense of analytical and critical thinking, and perhaps premature specialization if not over-specialization) may be ill-suited for the needs of a market economy. This study analyzes trends in four cross-country surveys of education performance: the Trends in International Mathematics and Sciences Study (TIMSS); the International Adult Literacy Survey (IALS); the Progress in International Reading Literacy Study (PIRLS); and the Program for International Student Assessment (PISA). Salient "quantity" of education indicators (enrollment and expenditure trends) are also assessed and compared with the "quality" of education indicators from results of the cross-national performance surveys.

Finally, drawing from both sets of indicators, transition countries were rated and ranked according to overall (measurable) educational deficiencies or education gaps. From a limited sample of sixteen transition countries (for which data existed for a majority of the twelve indicators used to rate the deficiencies), four countries stand out as the most vulnerable: Albania; Armenia; Macedonia; and Romania. 
USAID/E\&E/PO Working Paper Series on the Transition Countries

September 2006

No.1 Demography and Health (June 2005)

No.2 Education (October 2005)

No.3 Economic Reforms, Democracy, and Growth (November 2005)

No.4 Monitoring Country Progress in 2006 (September 2006)

No.5 Domestic Disparities (forthcoming)

No.6 Labor Markets (forthcoming)

No.7 Global Economic Integration (forthcoming)

The findings, interpretations, and conclusions expressed in these working papers are entirely those of the authors. They do not necessarily represent the view of USAID. The papers are available online at http://www.usaid.gov/locations/europe_eurasia. 


\section{Summary}

This paper attempts to synthesize and interpret the findings from a handful of cross-country assessments of the quality of education in the transition region. The conventional wisdom has been that educational aspects of human capital in the former Communist countries were largely an asset going into the transition. However, it has also been widely perceived that the type of education in the Communist countries (with emphases on memorization at the expense of analytical and critical thinking, and perhaps premature specialization if not over-specialization) may be ill-suited for the needs of a market economy.

We analyzed trends in four cross-country surveys of education performance: the Trends in International Mathematics and Sciences Study (TIMSS); the International Adult Literacy Survey (IALS); the Progress in International Reading Literacy Study (PIRLS); and the Program for International Student Assessment (PISA). Participation in the surveys among students in the transition countries remains limited. Hence, part of this analysis is also to revisit the salient enrollment and expenditure trends in the region and to compare them with the results of the cross-national performance surveys. To what extent can some of the quantity of education indicators be used as proxies for the quality of education?

TIMSS. Overall, the students sampled in fourteen transition countries included in this survey performed very well in 2003 by international standards. Eighth grade students in the Northern Tier CEE countries as well as in Russia performed roughly at OECD standards in math and science, and above the intermediate benchmark defined as the minimum acceptable level ("where students can recognize, apply and communicate basic math and scientific knowledge in straightforward situations.”). All the other transition countries included in the surveys except Macedonia performed at or near the intermediate benchmark. This includes Bulgaria, Serbia \& Montenegro, and Romania in the Southern Tier CEE, and Armenia and Moldova in Eurasia. Macedonia is the only transition country of the fourteen that lags notably behind the minimum threshold; its students performed closest to students in Iran, and not much better than students in Indonesia and Lebanon.

TIMSS trends over time (from 1995 to 2003) are limited to nine transition countries. Good progress has been made in performance scores in Lithuania and Latvia from 1995 to 2003. However, notable backsliding has occurred in four countries. Bulgaria has showed the biggest slide (it was the best performer of the fourteen countries in 1995). Macedonia, Russia, and Slovakia also witnessed backtracking during this time period as well.

IALS. Only four Northern Tier CEE countries are included in the IALS assessments of "functional literacy" which took place from 1994-1998. In three of the four Northern Tier CEE countries (Poland, Slovenia and Hungary), only 26-36\% of the adult population sampled scored at least the minimum level of " 3 ", and hence by IALS definition were able to at least minimally cope with the demands of advanced society. Adults in the Czech Republic, in contrast, had scored slightly above the OECD average. Of the three subject areas, adults in all four transition countries scored much lower on prose (or the knowledge and skills needed to understand and use information from texts, including editorials, news stories, poems, and fiction), higher on document literacy (the knowledge and skills required to locate and use information contained in various formats, including job applications, payroll forms, transport schedules, maps, tables, and 
graphics), and highest on quantitative literacy (the knowledge and skills required to apply arithmetic operations, either alone or sequentially, to numbers in printed materials). Adults in the OECD countries scored much more balanced results across the three subject areas, at least on average.

PIRLS. Most of the fourth grade students of the eleven transition countries included in PIRLS scored on par with OECD standards in 2001 according to PIRLS measures of reading literacy (which included "literary" and "informative”). In fact, only students in Macedonia lagged considerably behind the OECD threshold, and performed not much better than students in Colombia and Iran. In contrast to the mixed gender results in the TIMSS, girls consistently outperformed boys across all the eleven transition countries. This gender gap also held true in the OECD.

PISA. There are roughly three levels of outcomes in the transition sample of eleven countries in the PISA tests in 2003: (1) the five Northern Tier CEE countries are all OECD standard; (2) Russia followed by Bulgaria, Romania and Serbia \& Montenegro perform at a middle level, well below OECD standards, comparable to Thailand; and (3) Macedonia and Albania much lower score still, comparable to Tunisia, Indonesia, Brazil. Unfortunately, Russia to date is the only Eurasian country to take part in the PISA.

In general, students aged fifteen years across the transition performed best in science, worst in reading, and somewhere in between on math in PISA. In contrast, in the OECD countries, the scores across the three areas were comparable, at least on average. Girls outperformed boys in general in the transition countries. This was also the trend in OECD.

Larger communities have generally outperformed smaller communities in most of the transition countries sampled. These urban-rural disparities also appear in the OECD countries though they are not as great. Urban-rural disparities in PISA performances are particularly large in Bulgaria, followed by Hungary, Albania, and Romania.

Close to $20 \%$ of the students polled in the OECD countries claimed to be hindered either "somewhat" or "a lot" as a result of poor heating or cooling or lighting. Students in the four Northern Tier CEE countries included in the survey fared better; i.e., fewer assert that they are hindered by these constraints, ranging from only 2-3\% in Hungary and the Czech Republic to $10 \%$ in Poland to almost 15\% in Latvia. The Southern Tier leaders of Romania and Bulgaria are about OECD average on this score. In contrast, a much higher percentage of students in Macedonia and particularly in Russia and Albania contend that they are hindered by these constraints, roughly one-half of students in Russia and Macedonia. Students hindered by poor heating, cooling, and/or lighting systems, with two exceptions (in Poland and Romania), performed worse in the PISA tests than "non-hindered" students.

The data show that a lack of instruction materials pose a considerably larger constraint than poor heating, cooling, and lighting for students surveyed in the transition countries. Results range from $12 \%$ of students hindered in Hungary to $65 \%$ in Russia as a result of a lack of instruction materials. A very high percentage of students surveyed in Macedonia, Romania, Latvia, and 
Albania also contended that a lack of instruction material was an obstacle. In addition, performance has suffered more from this constraint than poor heating, etc.

Enrollment trends revisited. Secondary school enrollments have generally suffered more during the transition than enrollments at other levels of schooling. Most of the drop in secondary enrollments, however, has occurred in Eurasia where enrollments overall have fallen substantially, from almost $70 \%$ in 1989 to 50\% in 2002. Secondary school enrollments are higher today in CEE than when the transition began. In addition, when one disaggregates secondary school enrollments between general secondary and vocational/technical secondary, one finds that most of the drop in secondary school enrollments has been due to a significant drop in vocational or technical school enrollments, again mostly in Eurasia.

A reduction in the proportion of vocational enrollments relative to general enrollments from 1989 to 2002 occurred in twenty-two of the twenty-five countries for which data are available. In general, a drop in this ratio occurred in the CEE countries because vocational and technical enrollments remained relatively stable as general secondary enrollment rates increased. In contrast, the proportion of vocational and technical to general secondary dropped in Eurasia due primarily to a more than proportionate decrease in vocational and technical enrollments than a more moderate decline in general secondary enrollments.

In 1989, the large majority of transition countries had higher enrollments in vocational and technical schools than in general secondary schools: seventeen countries vs. eight. Most of the countries with a higher proportion of vocational schools are in CEE (and conversely, most of the Eurasian countries, seven countries, had general enrollment rates higher than vocational rates in 1989). The Southern Tier CEE countries had the highest proportion of vocational enrollment to general; six to seven times more vocational secondary enrollments in Macedonia, Croatia, and Romania than general secondary enrollments in 1989.

By 2002, there was much more balance between the number of countries where vocational enrollment exceeded general secondary (fourteen countries) and the number of countries where general secondary enrollments exceeded vocational (thirteen). There was a larger proportionate drop in vocational enrollments in CEE than in Eurasia from 1989 to 2002, reflecting in part that there was a larger proportion of vocational enrollments in CEE in 1989.

Quality vs. Quantity. We regressed the results from the PISA surveys on six quantity of education indicators to see how closely they correlate. Are any of the quantity of education indicators notably better than others as proxies for quality? Most of the correlations are weak, the "fit" between quantity and quality indicators are poor ones. The best fit between quantity and quality of education indicators is with higher education enrollment rates. Here, there exists a clear and consistent relationship between tertiary enrollments and PISA test results: the greater is the tertiary enrollment, the better are the test results. The r-square is 0.64 , and there are no obvious outliers. This is not to suggest causality from one to the other. Rather, countries that have education systems which invest more in higher education are also those that are more likely to produce a higher quality, more relevant education overall (i.e. not confined to higher education). 
Education gaps. We analyzed which countries appeared to be particularly vulnerable on each education indicator, quantity plus quality, and ranked the countries accordingly. There are many data gaps, particularly for the quality of education indicators. Hence, the overall education deficiencies per country were assessed by calculating the vulnerabilities as a percent of the indicators in which data are available. There were a total of twelve indicators. However, for only two countries, the Czech Republic and Hungary, were there data available for each of these twelve indicators. Seven other countries had data available for ten or eleven indicators. At the other extreme, three countries, Bosnia-Herzegovina, Uzbekistan, and Kazakhstan, had data for only four of the twelve indicators. Given the wide range of available data per country, we produced two lists of vulnerable countries: those with the highest proportion of vulnerable indicators (regardless of the number of indicators per country being tracked); and the most vulnerable countries from a smaller country sample consisting of those countries which have data for a majority (seven or more) of the twelve indicators.

From the full sample of twenty-seven countries, ten were found to have at least $50 \%$ of education indicators deemed vulnerable. Four are CEE countries: Bosnia-Herzegovina; Albania, Macedonia, and Romania. Six are Eurasian countries: Turkmenistan, Tajikistan, Armenia, Azerbaijan; Uzbekistan, and Georgia. From the limited sample of sixteen countries (which have data for a majority of the twelve indicators), four countries stand out as the most vulnerable: Albania; Armenia; Macedonia; and Romania.

Finally, it is important to underscore that there remain numerous data gaps; many "missing pieces to the puzzle.” Most Eurasian countries are not currently included in any of the crossnational performance tests, though a number more are scheduled to be included in the next couple years. Even still, the test results among the four cross-national assessments are not readily interchangeable. Moreover, we have even less data of trends over time. Only TIMSS and PISA tests have surveyed students from a handful of countries more than once, and the results provide only clues of possible trends over time, creating as many questions as answers. 


\section{Introduction and Methodology ${ }^{1}$}

The primary objective of this paper is to analyze the quality of education in the transition region. Much empirical analysis has focused on the "quantity" of education, such as enrollment and education expenditure trends, in no small part because most of the available empirical evidence pertains to the quantity rather than the quality of education. This paper attempts to synthesize the findings from a handful of cross-country assessments which in turn attempt to measure progress across students and/or adults worldwide towards achieving certain academic standards and perhaps more importantly, progress towards preparing students for employment in the global market economy.

The conventional wisdom has been that educational aspects of human capital in the former Communist countries were largely an asset going into the transition. The priority under the communist system for universal education was high and hence so were enrollments; performances in various global forums in the sciences and math among students from behind the Iron Curtain were impressive. However, it has also been widely perceived that the type of education in the Communist countries (with emphases on memorization at the expense of analytical and critical thinking, and perhaps premature specialization if not over-specialization) may be ill-suited for the needs of a market economy.

Below, we analyze trends in four cross-country surveys on education performance: the Trends in International Mathematics and Sciences Study (TIMSS); the International Adult Literacy Survey (IALS); the Progress in International Reading Literacy Study (PIRLS); and the Program for International Student Assessment (PISA). Participation in the surveys among transition countries remains limited, though it is increasing. Most of the transition countries included are in Central and Eastern Europe (CEE) and few are in Eurasia (where one might expect the quality of education may be the most troublesome). Hence, part of this analysis is also to revisit the salient enrollment and expenditure trends in the region and to compare them with the results of the cross-national surveys. To what extent can some of the quantity of education indicators be used as proxies for the quality of education? Or similarly, how meaningful are the quantity of education indicators? To what extent can we extrapolate the limited evidence from the quality of education surveys to countries not yet included in these surveys?

Table 1 shows the transition countries that have participated in the four surveys to date, as well as countries scheduled to participate in the near future (in 2006 and 2007). Sixteen transition countries have so far been included in at least one of the surveys. By 2007, twenty-five transition countries will have participated in at least one survey; i.e., all but Turkmenistan and Tajikistan. This is not to suggest, as should be evident in the analyses to follow, that the various surveys are necessarily readily inter-changeable.

Table 2 shows the complete sample of countries worldwide included in the surveys to date. Sample sizes range from twenty countries in the IALS (all OECD countries), to fifty-five countries in the TIMSS. In general, the developing countries are under-represented in these surveys even more so than the transition countries.

\footnotetext{
${ }^{1}$ Many thanks to Luba Fajfer of E\&E/DGST for her very helpful feedback and insights on earlier drafts of this research.
} 
Table 3 provides the basic parameters of each of the four surveys. TIMSS is designed to test academic achievement in the areas of mathematics (numbers, fractions, algebra, and geometry) and the sciences (including chemistry, the life sciences, and physics) amongst students in approximately grade eight. TIMSS more directly assesses student achievement than it does "real world" applicability. That is, it primarily tests a student's ability to retain and recall information learned during instruction. The International Association for the Evaluation of Educational Achievement (IEA) conducts the assessment every four years. The IEA is an independent international cooperative of national research institutions and government agencies that has been conducting studies of cross-national achievement since 1959. To date, there exist TIMSS results from 1995, 1999, and 2003. The next round will be completed in 2007. The 2003 round surveyed the achievements of 49 countries — 36 of which had also participated in either the 1995 and 1999 rounds. TIMSS has assessed the student performance of fourteen countries in the E\&E transition region. Of these, seven belong to the Northern Tier CEE, four to the Southern Tier CEE, and three to Eurasia.

PIRLS, also administered by the IEA, focused on two aspects of reading literacy (literary and informative) in students in the fourth grade in 2001. The target group is the youngest of all four cross-country assessments. PIRLS assessments took place in thirty five countries worldwide, including eleven transition countries. The next round will take place in 2006.

The IALS study was conducted by the OECD and focused on adults' ability to utilize information to function in the context of advanced, complex societies. IALS defines literacy as the ability to understand and employ printed information in daily activities, at home, at work, and in the community, to achieve one's goals and to develop one's potential. It attempts to measure functional literacy in three areas: prose, document, and quantitative. Prose literacy is defined as the knowledge and skills needed to understand and use information from texts, including editorials, news stories, poems, and fiction. Document literacy is defined as the knowledge and skills required to locate and use information contained in various formats, including job applications, payroll forms, transport schedules, maps, tables, and graphics. Quantitative literacy is defined as the knowledge and skills required to apply arithmetic operations, either alone or sequentially, to numbers in printed materials. For each area, IALS scores are grouped into four levels-level four representing the highest level of literacy and level one representing the lowest. ${ }^{2}$ IALS defines literacy level three as the minimum level required to function in advanced, complex societies. As such, our attention will be focused on the percentage of respondents scoring at or above this level. The one and only IALS assessment was

\footnotetext{
${ }^{2}$ Level 1 - Indicates a person with very poor skills, where the person may, for example, be unable to determine the correct amount of medicine from printed information.

Level 2 - Respondents can deal only with material that is simple, clearly laid out, and in which the tasks involved are not too complex. It denotes a weak level of skill, but more hidden than level 1. It identifies people who can read, but test poorly. They may have developed coping skills to manage everyday literacy demands, but their low level of proficiency makes it difficult for them to face novel demands, such as learning new job skills. Level 3 - Is considered a suitable minimum for coping with the demands of everyday life and work in complex, advanced society. It denotes roughly the skill level required for successful secondary school completion and college entry. Like higher levels, it requires the ability to integrate several sources of information and solve complex problems. Level 4 - describes respondents who demonstrate command of higher-order information processing skills.
} 
carried out between 1994 and 1998 and tested the literacy of adults aged 16 to 65 in twenty countries. Of these, only four belong to the $E \& E$ transition region and all are in the Northern Tier CEE.

The PISA study, also conducted by the OECD, also adopts the IALS' broad definition of literacy. In particular, PISA attempts to focus on how well students, aged approximately fifteen, use knowledge in reading, mathematics, and science to meet real-world challenges. The OECD conducts the assessment every three years. Assessments have already been administered in both 2000 and 2003; the next round will be completed in 2006. ${ }^{3}$ Forty-five countries have participated in at least one of the PISA surveys. Of these, eleven belong to the transition region-five from the Northern Tier CEE, five from the Southern Tier CEE, and Russia. Only five E\&E countries participated in both 2000 and 2003.

\section{Findings}

TIMSS. Figures 1-4 and Tables 4 and 5 show the primary results from TIMSS. Overall, the students sampled in fourteen transition countries included in this survey performed very well in 2003 by international standards. Students in the Northern Tier CEE countries as well as in Russia performed roughly at OECD standards in math and science, and above the intermediate benchmark defined as the minimum acceptable level ("where students can recognize, apply and communicate basic math and scientific knowledge in straightforward situations.”) (Table 4 and Figures 1 and 2). All the other transition countries included in the surveys except Macedonia performed at or near the intermediate benchmark. This includes Bulgaria, Serbia \& Montenegro, and Romania in the Southern Tier CEE, and Armenia and Moldova in Eurasia.

Macedonia is the only transition country of the fourteen that lags notably behind the minimum threshold; its students performed closest to students in Iran, and not much better than students in Indonesia and Lebanon. Of the fifty-five countries worldwide included in at least one of the surveys, South Africa and Ghana lag the most and far below standards in the fourteen transition countries, including Macedonia. However, only two of the relatively low-income transition countries (Armenia and Moldova) have so far been included in the TIMSS.

On average, boys outperform girls in both the math and science in the TIMSS tests in the OECD countries (Table 5 and Figure 3). This is the pattern in the United States as well. This gender gap in the OECD countries is larger in science than in math. The pattern is more mixed in the fourteen transition countries. While boys outperform girls in science in ten of the fourteen transition countries, girls outperform boys in math in ten transition countries. In many cases, the differences are likely not very significant. The largest overall gaps exist in the transition countries at both ends of the performance spectrum.

\footnotetext{
${ }^{3}$ Subsequent to the PISA 2000 round which involved predominately OECD countries, the assessment was repeated between 2001 and 2002 in eleven non-OECD countries in an exercise entitled PISA+. OECD officially publishes these results with those from PISA 2000.
} 
That is, in the transition countries which score the highest (in Hungary and the Czech Republic in particular), boys outperform girls by a relatively large amount, while in the countries which score the lowest (Macedonia and Armenia in particular), the gap is also large, albeit reversed: girls outperform boys.

Figure 4 shows the limited data of TIMSS trends over time in nine transition countries (and in the U.S.), comparing the 1995 survey with 1999 and the most recent, 2003. Good progress has been made in performance scores in Lithuania and Latvia from 1995 to 2003. However, notable backsliding has occurred in four countries. Bulgaria has showed the biggest slide (it was the best performer of the fourteen countries in 1995). Macedonia, Russia, and Slovakia also witnessed backtracking during this time period as well. This is particularly striking for Macedonia since it was the worst performer of the transition sample in 1995.

IALS. The key IALS results are shown in Table 6 and Figures 5 and 6 . In three of the four Northern Tier CEE countries (Poland, Slovenia and Hungary), only 26-36\% of the population sampled in 1994-1998 scored at least the minimum level of "3", and hence by IALS definition were able to at least minimally cope with the demands of advanced society. The Czech Republic, in contrast, has a score that slightly exceeded the OECD average; in the Czech Republic, 58\% of the population surveyed tested above the minimum acceptable threshold. In general, the results are striking in how low the percentage of the population virtually everywhere is "functionally literate"; roughly half of the population in the OECD and also in the U.S. failed to attain this minimum threshold. The best scores were found in Sweden (75\% above the threshold) and Norway (69\%).

In the OECD (and including in the U.S.), the results according to the three subject areas-prose, document, and quantitative-were roughly even (Figure 6 and Table 6). In contrast, the results were much more imbalanced in the four transition countries; that is, much more favorable results in quantitative tests and much weaker and weakest in prose.

The conclusions from the IALS are limited not only because of the small transition country sample, but also because the 1994-1998 findings are now notably dated, particularly so in the context of the context of much transformation in the region.

PIRLS. (Table 7 and Figures 7 and 8). Most of the eleven transition countries scored on par with OECD standards; overall, better results than shown in the IALS. In fact, only Macedonia lagged considerably behind the OECD threshold, and not much better than results in Colombia and Iran. In contrast to the mixed results in the TIMSS, girls consistently outperformed boys across all the eleven transition countries as well as in the OECD (and including the U.S.).

PISA. Tables 8-11 and Figures 9-17 show the PISA results. From Figure 9, there are roughly three levels of outcomes in the transition sample: (1) the five Northern Tier CEE countries are all OECD standard (and Hungary and Poland do better here than in the 1994-1998 IALS, perhaps because science scores in PISA are pulling up the 
performance, and/or perhaps because performances have improved from 1994-1998 to 2003); (2) Russia followed by Bulgaria, Romania and Serbia \& Montenegro perform at a middle level, well below OECD standards, comparable to Thailand; and (3) Macedonia and Albania much lower score still, comparable to Tunisia, Indonesia, Brazil. Unfortunately, Russia to date is the only Eurasian country to take part in the PISA.

Figure 10 and Table 8 show the scores disaggregated by the three domains or areas: reading, math, and science. In general, students across the transition perform best in science and worst in reading. In contrast, in the OECD countries, the scores across the three areas are comparable, at least on average.

Females outperform males in general in the transition country sample (Figure 11 and Table 9). This is also the trend in OECD. The gender gap is greatest in the transition sample where the overall scores are the lowest, i.e., in Albania and Macedonia. Of the three areas, this gender gap is the largest in reading (i.e., in all eleven transition countries, females outperform males in reading). In math and science, females outperform males in a majority of the countries; in six out of eleven in math and in seven out of eleven in science.

PISA tests have taken place in 2000 and 2003 in only five transition countries: four Northern Tier CEE countries (Latvia, Hungary, Poland, and the Czech Republic) and Russia (Figure 12). Some gains in performance were made in the four Northern Tier CEE countries from 2000-2003, particularly in Latvia followed by Poland. Performance in Russia held steady between 2000 and 2003. By way of contrast, some backsliding occurred in the U.S. in this period.

Figure 13 and Table 10 show PISA results differentiated by community size. These results, i.e., roughly show the extent of urban-rural disparities. Larger communities (that is, with population more than 15,000) have generally outperformed smaller communities (with population less than 15,000) in most of the transition countries sampled. These urban-rural disparities also appear in the OECD countries though they are not as great. In the transition country sample, the urban-rural disparity is the largest in Bulgaria, followed by Hungary, Albania, and Romania. This trend does not exist in the U.S., however, where i.e., smaller communities outperform larger communities. Nor does it hold true in Macedonia, the lone exception among the transition country sample.

These findings by community size hold whether one averages the three areas or whether one looks at each area separately. In other words, of the eleven transition countries, only in Macedonia do smaller communities score higher than larger communities in each of the three areas: in reading, math and science.

Table 11 and Figures 14-17 summarize efforts to assess the magnitude and impact of key infrastructure constraints to learning. Specifically, how much have students sampled in PISA been constrained in their performance by poor conditions in school buildings, poor heating/cooling and/or lighting systems, and by a lack of instruction materials? Close to $20 \%$ of the students polled in the OECD countries claimed to be hindered either 
"somewhat" or "a lot" as a result of poor heating or cooling or lighting (Figure 14). Students in the four Northern Tier CEE countries included in the survey fare better; i.e., fewer assert that they are hindered by these constraints, ranging from only 2-3\% in Hungary and the Czech Republic to $10 \%$ in Poland to almost $15 \%$ in Latvia. The Southern Tier leaders of Romania and Bulgaria are about OECD average on this score. In contrast, a much higher percentage of students in Macedonia and particularly in Russia and Albania contend that they are hindered by these constraints, roughly one-half of students in Russia and Macedonia.

Figure 15 assesses whether these constraints manifest in poorer test results. For each country, performance among students claiming to be hindered was compared with performance among students claiming not to be hindered. Students hindered by poor heating, cooling, and/or lighting systems, with two exceptions (in Poland and Romania), performed worse than "non-hindered" students. The largest differential was found in Macedonia; i.e., these constraints of poor heating or cooling or lighting had the biggest detrimental impact in Macedonia.

The data show that a lack of instruction materials pose a considerably larger constraint than poor heating, cooling, and lighting for students surveyed in the transition countries (Figure 16). Moreover, this finding is the reverse of that among students in the OECD countries on average. Results range from $12 \%$ of students hindered in Hungary to $65 \%$ in Russia. A very high percentage of students surveyed in Macedonia, Romania, Latvia, and Albania also contended that a lack of instruction material was an obstacle. In addition, performance has suffered more from this constraint than poor heating, etc. (Figure 17). Hindered students consistently perform worse with this constraint than nonhindered students; the detrimental impact is particularly evident in Macedonia, Bulgaria, Poland, and Hungary.

Quality of education indicators compared. One question to consider, particularly given the limited countries involved, is to what extent might the results of the four crosscountry surveys (i.e., the TIMSS; IALS, PIRLS, and PISA) be inter-changeable? To what extent can one be used as a proxy for another? If, for example, Moldova students score poorly on one test, how precarious might it be to infer that Moldovan students would likely score poorly on another? One preliminary way to get at this issue is to measure the correlation between two different sets of scores. We find some surprising results when we do so. Despite similar conceptual bases, the correlation between results in PISA and IALS is very low (an r-square of 0.37; Figure 18). Perhaps this reflects a changing situation over time. In contrast, PISA results and TIMSS scores correlate quite well even though these surveys don't particularly mesh well conceptually. This relatively good fit holds when one compares results of transition country students only (r-square of 0.79; Figure 19) and similarly with the larger worldwide sample (r-square of 0.74; Figure 20).

Enrollment trends revisited. Secondary school enrollments have generally suffered more during the transition than enrollments at other levels of schooling (Figures 21-24). Most 
of the drop in secondary enrollments, however, has occurred in Eurasia where enrollments overall have fallen substantially, from almost 70\% in 1989 to 50\% in 2002. Secondary school enrollments are higher today in CEE than when the transition began. In addition, when one disaggregates secondary school enrollments between general secondary and vocational/technical secondary, one finds that most of the drop in secondary school enrollments has been due to a significant drop in vocational or technical school enrollments, again mostly in Eurasia (Figures 25 and 26).

Figures 27-32 and Tables 12-14 show secondary school enrollment trends (total, general, and vocational/technical) for all of the Southern Tier CEE and Eurasian countries individually. They show that the sub-regional (average) trends mask considerable diversity. Total secondary enrollments in the Southern Tier CEE countries range from Croatia and Bulgaria at 85\% to Albania and Bosnia-Herzegovina at 50\%. In Eurasia, total secondary enrollments range from Belarus and Russia at $70 \%$ to Tajikistan and Turkmenistan at less than $30 \%$.

Moreover, some countries rank very differently in enrollment levels when one compares vocational/technical enrollments with general enrollments. Most striking is Albania. Albania, alongside Bulgaria, has the highest general secondary enrollment rate in the Southern Tier CEE countries, yet the lowest secondary school enrollment rate in vocational/technical schools. Croatia has the highest vocational enrollment rate in the Southern Tier CEE, yet is among the laggards in general secondary school enrollment. Armenia has among the highest general secondary school enrollment in Eurasia, but also among the lowest vocational/technical enrollments rates.

Table 15 looks at the composition of secondary school enrollments more systematically. What was the mix of vocational to general enrollments rates in 1989? What is the proportion roughly today (2002 most recent data)? How has it changed from 1989 to 2002? Overall, there is a great deal of diversity of results among the countries. Perhaps the most evident general trend is the reduction in the proportion of vocational enrollments relative to general enrollments from 1989 to 2002. This occurred in twenty-two of the twenty-five countries for which data are available.

In 1989, the large majority of transition countries had higher enrollments in vocational and technical schools than in general secondary schools: seventeen countries vs. eight. Most of the countries with a higher proportion of vocational schools are in CEE (and conversely, most of the Eurasian countries, seven countries, had general enrollment rates higher than vocational rates in 1989). The Southern Tier CEE countries had the highest proportion of vocational enrollment to general; six to seven times more vocational secondary enrollments in Macedonia, Croatia, and Romania than general secondary enrollments in 1989.

By 2002, there was much more balance between the number of countries where vocational enrollment exceeded general secondary (fourteen countries) and the number of countries where general secondary enrollments exceeded vocational (thirteen). There was a larger proportionate drop in vocational enrollments in CEE than in Eurasia from 
1989 to 2002, reflecting in part that there was a larger proportion of vocational enrollments in CEE in 1989.

The meaning of these trends needs to be explored. Can one generalize to say that a proportionate drop in vocational and technical school enrollments is a good thing given the overspecialization that took place prior to communism's collapse? Is this trend a necessary part of the transition to a market-oriented democracy? To what extent does the quality and appropriateness of vocational and technical training differ across countries? Are there key differences between vocational schools and technical schools? We are not aware of an effort which has attempted to systematically address these questions.

Quality vs. quantity. We regressed the results from the PISA surveys on six quantity of education indicators to see how closely they correlate (Figures 33-39). Are any of the quantity of education indicators notably better than others as proxies for quality? The six indicators are: basic or primary school enrollment; total secondary school enrollment; general secondary enrollment; vocational/technical enrollment; tertiary or higher education enrollment; and public spending on education as \% of GDP.

Most of the correlations are weak, the "fit" between quantity and quality indicators are poor ones. Perhaps surprisingly, the poorest fit is between general school enrollments and the PISA scores (an r-square of 0.05); countries with roughly the same general enrollment rates have very different PISA scores (Albania vs. Hungary, e.g.). Vocational enrollment rates correlate somewhat better, though the fit is still poor. However, when one combines the two secondary school enrollment rates, one finds a reasonable fit (tempered by two significant outliers: Macedonia and Albania). In general, the greater is the total secondary enrollment, the better are the PISA test results.

Basic enrollment figures do not correlate very closely with PISA results; a very low rsquare. However, the same two outliers, Macedonia and Albania, emerge. This may suggest that the primary and secondary education systems in Macedonia and Albania are more inefficient than the norm among the transition countries.

In addition, the amount a government spends on education does not correlate very well with PISA test results. The efficiency and targeting of expenditures may be more important than the volume of spending.

The best fit between quantity and quality of education indicators is with higher education enrollment rates. Here, there exists a clear and consistent relationship between tertiary enrollments and PISA test results: the greater is the tertiary enrollment, the better are the test results. The r-square is 0.64 , and there are no obvious outliers. This is not to suggest causality from one to the other. Rather, countries that have education systems which invest more in higher education are also those that are more likely to produce a higher quality, more relevant education overall (i.e. not confined to higher education). 
Education gaps. Finally, in a similar vein (albeit in a less sophisticated mode) to previous "hot spots" analyses conducted by the E\&E Bureau, ${ }^{4}$ we analyzed which countries appeared to be particularly vulnerable on each education indicator, quantity plus quality, and ranked the countries accordingly. Table 17 summarizes the results and includes threshold definitions of vulnerability. There are many data gaps, particularly for the quality of education indicators. Hence, the overall education deficiencies per country were assessed by calculating the vulnerabilities as a percent of the indicators in which data are available. There were a total of twelve indicators: enrollments at all levels, education expenditures; the quality of education survey indicators, as well as a proxy indicator to measure "brain drain" (Table 16 and Figure 40). ${ }^{5}$ However, for only two countries, the Czech Republic and Hungary, was there data available for each of these twelve indicators. Seven other countries had data available for ten or eleven indicators. At the other extreme, three countries, Bosnia-Herzegovina, Uzbekistan, and Kazakhstan, had data for only four of the twelve indicators. Given the wide range of available data per country, it seemed appropriate to produce two lists of vulnerable countries: those with the highest proportion of vulnerable indicators (regardless of the number of indicators per country being tracked); and the most vulnerable countries from a smaller country sample consisting of those countries which have data for a majority (seven or more) of the twelve indicators.

From the full sample of twenty-seven countries, ten were found to have at least $50 \%$ of education indicators deemed vulnerable. Four are CEE countries: Bosnia-Herzegovina; Albania, Macedonia, and Romania. Six are Eurasian countries: Turkmenistan, Tajikistan, Armenia, Azerbaijan; Uzbekistan, and Georgia. From the limited sample of sixteen countries (which have data for a majority of the twelve indicators), four countries stand out as relatively vulnerable: Albania; Armenia; Macedonia; and Romania.

We provide a visual summary of the education profiles of two of these four vulnerable countries: Macedonia (Figures 41 and 42) and Albania (Figures 43 and 44).

Macedonia's enrollment trends are relatively favorable (Figure 41). There has been little deterioration in enrollment numbers. However, the pre-primary enrollment rate in Macedonia is only 27\%, well below regional standards (Eurasia: 32\%; Southern Tier CEE: 52\%; and Northern Tier CEE: 72\%). In addition, tertiary enrollment is very low in Macedonia relative to Northern Tier CEE standards (23\% vs. 50\%), though not Southern Tier CEE and Eurasian averages (24\% and 26\% respectively).

Macedonia falls far short by various standards from the PISA assessments (Figure 42). The performance of its students is dwarfed by OECD standards, across the three subject areas (and most saliently, reading), and by gender (most saliently, males). A high percentage of students in Macedonia are hindered by school infrastructure (heating, cooling, and/ lighting systems), and particularly by a lack of instructional materials;

\footnotetext{
${ }^{4}$ See USAID/EE/DGST, Social Issues Critical for Sustainability of Reform: Education Sector Discussion Paper (August 2003).

${ }^{5}$ The "brain drain" proxy, drawn from UNESCO, measures the change of the research and development personnel per million inhabitants between two time periods, 1994-1996 vs. 1999-2001.
} 
almost half of the students surveyed found themselves hindered by a lack of instructional materials (vs. $17 \%$ of students surveyed in the OECD countries).

Enrollment trends in Albania are troublesome (Figure 43). Secondary school enrollment rates have dropped significantly since 1989 , from almost $80 \%$ to $50 \%$. All of this drop is attributed to vocational and technical enrollments plummeting (while general secondary enrollment rates increased modestly). Pre-primary enrollment rate is only $34 \%$, and the tertiary enrollment rate is only $14 \%$.

Albanian students scored very poorly on the PISA test, even worse than students in Macedonia. Over $50 \%$ of students surveyed are hindered by heating, cooling, and/or lighting; 57\% are hindered by a lack of instruction materials. Large disparities exist by gender (males lag considerably) and by subject areas (Albanian's score much poorer on reading than on math and science), and by community size (performance of rural students are far below those of urban students).

One last observation from this rack-up of education gaps merits explicit attention. It is striking how little quantitative information we have on a number of transition countries. Of a total of twelve indicators, we have data for only four indicators in the case of Bosnia-Herzegovina, Uzbekistan, and Kazakhstan; five in the case of Turkmenistan, Tajikistan, Azerbaijan, and Croatia; and six in the case of Georgia, Ukraine, and Belarus. In eight of the twelve Eurasian countries, we have no more than half of the indicators available. Moreover, the data gaps may very likely be a reasonable proxy for relatively unreliable indicators where data do exist. 


\begin{tabular}{|c|c|c|c|c|c|c|c|c|c|c|}
\hline & & & & & IALS & & PISA & & & \\
\hline & 1995 & 1999 & 2003 & 2007 & $(94-98)$ & 2000 & 2003 & 2006 & 2001 & 2006 \\
\hline Albania & & & & & & $x$ & & & & \\
\hline Armenia & & & $x$ & $x$ & & & & & & \\
\hline Azerbaijan & & & & & & & & $x$ & & \\
\hline Belarus & & & & & & & & & & $x$ \\
\hline Bosnia-Herzegovina & & & & $x$ & & & & & & \\
\hline Bulgaria & $x$ & $x$ & $x$ & $x$ & & $x$ & & $x$ & $x$ & $x$ \\
\hline Croatia & & & & & & & & $x$ & & \\
\hline Czech Republic & $x$ & $x$ & & $x$ & $x$ & $x$ & $x$ & $x$ & $x$ & \\
\hline Estonia & & & $x$ & & & & & $x$ & & \\
\hline Georgia & & & & $x$ & & & & & & $x$ \\
\hline Hungary & $x$ & $x$ & $x$ & & $x$ & $x$ & $x$ & $x$ & $x$ & $x$ \\
\hline Kazakhstan & & & & & & & & $x$ & & \\
\hline Kyrgyzstan & & & & & & & & $x$ & & \\
\hline Latvia & $x$ & $x$ & $x$ & $x$ & & $x$ & $x$ & $x$ & $x$ & $x$ \\
\hline Lithuania & $x$ & $x$ & $x$ & $x$ & & & & $x$ & $x$ & $x$ \\
\hline FYR Macedonia & & $x$ & $x$ & & & $x$ & & & $x$ & $x$ \\
\hline Moldova & & $x$ & $x$ & $x$ & & & & & $x$ & $x$ \\
\hline Poland & & & & & $x$ & $x$ & $x$ & $x$ & & $x$ \\
\hline Romania & $x$ & $x$ & $x$ & $x$ & & $x$ & & $x$ & & $x$ \\
\hline Russia & $x$ & $x$ & $x$ & $x$ & & $x$ & $x$ & $x$ & $x$ & $x$ \\
\hline Serbia \& Montenegro & & & & $x$ & & & $x$ & $x$ & & \\
\hline Slovakia & $x$ & $\mathrm{x}$ & $x$ & $x$ & & & $x$ & $\mathrm{x}$ & $\mathrm{x}$ & $x$ \\
\hline Slovenia & $x$ & $x$ & $x$ & $x$ & $x$ & & & $x$ & $x$ & $x$ \\
\hline Ukraine & & & & $x$ & & & & & & \\
\hline Uzbekistan & & & & $x$ & & & & & & \\
\hline Total (25 Countries) & 9 & 11 & 12 & 14 & 4 & 8 & 7 & 16 & 10 & 13 \\
\hline
\end{tabular}

TIMSS 2007 is in its preliminary stages, countries listed are those that have expressed interest in participating. 


\section{Table 2. Countries Participating in Cross-National Assessments}

\begin{tabular}{|c|c|c|c|c|c|c|}
\hline PISA 2000 & PISA 2003 & IALS & TIMSS 2003 & TIMSS 1999 & TIMSS 1995 & PIRLS \\
\hline $\begin{array}{l}\text { Albania } \\
\text { Argentina } \\
\text { Austia } \\
\text { Australia } \\
\text { Belgium } \\
\text { Brazil } \\
\text { Bulgaria } \\
\text { Canada } \\
\text { Chile } \\
\text { Czech Republic } \\
\text { Denmark } \\
\text { Finalnd } \\
\text { France } \\
\text { FYR Macedonia } \\
\text { Germany } \\
\text { Greece } \\
\text { Hong Kong-China } \\
\text { Hungary } \\
\text { Iceland } \\
\text { Indonesia } \\
\text { Ireland } \\
\text { Israel } \\
\text { Italy } \\
\text { Japan } \\
\text { Korea } \\
\text { Latvia } \\
\text { Liechtenstein } \\
\text { Luxembourg } \\
\text { Mexico } \\
\text { Netherlands } \\
\text { New Zealand } \\
\text { Norway } \\
\text { Peru } \\
\text { Poland } \\
\text { Portugal } \\
\text { Romania } \\
\text { Russia } \\
\text { Spain } \\
\text { Sweden } \\
\text { Switzerland } \\
\text { Thailand } \\
\text { United Kingdom } \\
\text { USA } \\
\text { GA }\end{array}$ & $\begin{array}{l}\text { Australia } \\
\text { Austria } \\
\text { Belgium } \\
\text { Brazil } \\
\text { Canada } \\
\text { Czech Republic } \\
\text { Denmark } \\
\text { Finland } \\
\text { France } \\
\text { Germany } \\
\text { Greece } \\
\text { Hong Kong-China } \\
\text { Hungary } \\
\text { Iceland } \\
\text { Indonesia } \\
\text { Ireland } \\
\text { Italy } \\
\text { Japan } \\
\text { Korea } \\
\text { Latvia } \\
\text { Liechtenstein } \\
\text { Luxembourg } \\
\text { Macao-China } \\
\text { Mexico } \\
\text { Netherlands } \\
\text { New Zealand } \\
\text { Norway } \\
\text { Poland } \\
\text { Portugal } \\
\text { Russia } \\
\text { Serbia \& Montenegro } \\
\text { Slovakia } \\
\text { Spain } \\
\text { Sweden } \\
\text { Switzerland } \\
\text { Thailand } \\
\text { Tunisia } \\
\text { Turkey } \\
\text { United Kingdom } \\
\text { USA } \\
\text { Uruguay } \\
\text { Iiand }\end{array}$ & $\begin{array}{l}\text { Australia } \\
\text { Belgium } \\
\text { Canada } \\
\text { Chile } \\
\text { Czech Republic } \\
\text { Denmark } \\
\text { Finland } \\
\text { Germany } \\
\text { Hungary } \\
\text { Ireland } \\
\text { Netherlands } \\
\text { New Zealand } \\
\text { Norway } \\
\text { Poland } \\
\text { Portugal } \\
\text { Slovenia } \\
\text { Sweden } \\
\text { Switzerland } \\
\text { UK } \\
\text { USA }\end{array}$ & $\begin{array}{l}\text { Argentina } \\
\text { Armenia } \\
\text { Australia } \\
\text { Bahrain } \\
\text { Beligum } \\
\text { Botswana } \\
\text { Bulgaria } \\
\text { Canada } \\
\text { Chile } \\
\text { Chinese Taipei } \\
\text { Cyprus } \\
\text { Egypt } \\
\text { England } \\
\text { Estonia } \\
\text { Ghana } \\
\text { Hong King } \\
\text { Hungary } \\
\text { Indonesia } \\
\text { Iran } \\
\text { Israel } \\
\text { Italy } \\
\text { Japan } \\
\text { Jordan } \\
\text { S. Korea } \\
\text { Labanon } \\
\text { Latvia } \\
\text { Lithuania } \\
\text { Macedonia } \\
\text { Malaysia } \\
\text { Moldova } \\
\text { Morocco } \\
\text { Netherlands } \\
\text { New Zealand } \\
\text { Norway } \\
\text { Palestine } \\
\text { Philippines } \\
\text { Romania } \\
\text { Russia } \\
\text { Saudi Arabia } \\
\text { Scotland } \\
\text { Serbia } \\
\text { Singapore } \\
\text { Slovakia } \\
\text { Slovenia } \\
\text { South Africa } \\
\text { Spain-Basque } \\
\text { Sweden } \\
\text { Syria } \\
\text { Tunisia } \\
\text { USA } \\
\text { Yemen }\end{array}$ & $\begin{array}{l}\text { Argentina } \\
\text { Australia } \\
\text { Beligum } \\
\text { Bulgaria } \\
\text { Canada } \\
\text { Chile } \\
\text { China-Taipei } \\
\text { Cyprus } \\
\text { England } \\
\text { Hong King } \\
\text { Hungary } \\
\text { Indonesia } \\
\text { Iran } \\
\text { Israel } \\
\text { Italy } \\
\text { Japan } \\
\text { Jordan } \\
\text { S. Korea } \\
\text { Latvia } \\
\text { Lithuania } \\
\text { Macedonia } \\
\text { Malaysia } \\
\text { Moldova } \\
\text { Morocco } \\
\text { Netherlands } \\
\text { New Zealand } \\
\text { Philippines } \\
\text { Romania } \\
\text { Russia } \\
\text { Singapore } \\
\text { Slovakia } \\
\text { Slovenia } \\
\text { South Africa } \\
\text { Tunisia } \\
\text { USA }\end{array}$ & $\begin{array}{l}\text { Australia } \\
\text { Beligum } \\
\text { Bulgaria } \\
\text { Canada } \\
\text { Cyprus } \\
\text { England } \\
\text { Hong King } \\
\text { Hungary } \\
\text { Iran } \\
\text { Israel } \\
\text { Italy } \\
\text { Japan } \\
\text { S. Korea } \\
\text { Latvia } \\
\text { Lithuania } \\
\text { Netherlands } \\
\text { New Zeal. } \\
\text { Norway } \\
\text { Romania } \\
\text { Russia } \\
\text { Scotland } \\
\text { Singapore } \\
\text { Slovakia } \\
\text { Slovenia } \\
\text { South Africa } \\
\text { Sweden } \\
\text { USA }\end{array}$ & $\begin{array}{l}\text { Argentina } \\
\text { Belize } \\
\text { Bulgaria } \\
\text { Canada } \\
\text { Colombia } \\
\text { Cyprus } \\
\text { Czech Rep. } \\
\text { England } \\
\text { France } \\
\text { Germany } \\
\text { Greece } \\
\text { Hong King } \\
\text { Hungary } \\
\text { Iceland } \\
\text { Iran } \\
\text { Israel } \\
\text { Italy } \\
\text { Kuwait } \\
\text { Latvia } \\
\text { Lithuania } \\
\text { Macedonia } \\
\text { Moldova } \\
\text { Morocco } \\
\text { Netherlands } \\
\text { New Zealand } \\
\text { Norway } \\
\text { Russia } \\
\text { Scotland } \\
\text { Singapore } \\
\text { Slovakia } \\
\text { Slovenia } \\
\text { Sweden } \\
\text { Turkey } \\
\text { USA }\end{array}$ \\
\hline
\end{tabular}


Table 3. Cross-National Testing Assessments

\begin{tabular}{|c|c|c|c|c|}
\hline & $\begin{array}{c}\text { IALS } \\
\text { International Adult } \\
\text { Literacy Survey }\end{array}$ & $\begin{array}{c}\text { PISA } \\
\text { Program for } \\
\text { International Student } \\
\text { Assessment }\end{array}$ & $\begin{array}{c}\text { TIMSS } \\
\text { Trends in International } \\
\text { Mathematics and } \\
\text { Sciences Study }\end{array}$ & $\begin{array}{c}\text { PIRLS } \\
\text { Progress in } \\
\text { International Reading } \\
\text { and Literacy Study }\end{array}$ \\
\hline Countries & $\begin{array}{l}20 \text { Countries (4 E\&E) } \\
\text { Northern Tier CEE } \\
\text { Czech Republic, } \\
\text { Hungary, Poland, } \\
\text { Slovenia. }\end{array}$ & $\begin{array}{l}45 \text { Countries (11 } \\
\text { E\&E) } \\
\text { Northern Tier CEE } \\
\text { Czech Republic, } \\
\text { Hungary, Latvia, } \\
\text { Poland, Slovakia. } \\
\text { Southern Tier CEE } \\
\text { Albania, Bulgaria, FYR } \\
\text { Macedonia, Romania, } \\
\text { Serbia-Montenegro. } \\
\text { Eurasia } \\
\text { Russia. }\end{array}$ & $\begin{array}{l}55 \text { Countries (14 } \\
\text { E\&E) } \\
\text { Northern Tier CEE } \\
\text { Czech Republic, } \\
\text { Estonia, Hungary, } \\
\text { Latvia, Lithuania, } \\
\text { Slovakia, Slovenia. } \\
\text { Southern Tier CEE } \\
\\
\text { Bulgaria, FYR } \\
\text { Macedonia, Romania, } \\
\text { Serbia. } \\
\text { Eurasia } \\
\text { Armenia, Moldova, } \\
\text { Russia. }\end{array}$ & $\begin{array}{l}35 \text { Countries (11 } \\
\text { E\&E) } \\
\text { Northern Tier CEE } \\
\text { Czech Republic, } \\
\text { Hungary, Latvia, } \\
\text { Lithuania, Slovakia, } \\
\text { Slovenia. } \\
\text { Southern Tier CEE } \\
\end{array}$ \\
\hline Topics & $\begin{array}{l}\text { - Prose Literacy } \\
\text { - Document Literacy } \\
\text { - Quantitative Literacy }\end{array}$ & $\begin{array}{l}\text { - Reading } \\
\text { - Mathematics } \\
\text { - Science } \\
\end{array}$ & $\begin{array}{l}\text { - Mathematics } \\
\text { - Science }\end{array}$ & - Reading Literacy \\
\hline Years & 1994-1998 (1 Survey) & $2000 \& 2003$ & $1995,1999, \& 2003$ & 2001 \\
\hline Ages & Adults $16-65$ & 15 years old & 8th Grade & 4th Grade \\
\hline
\end{tabular}




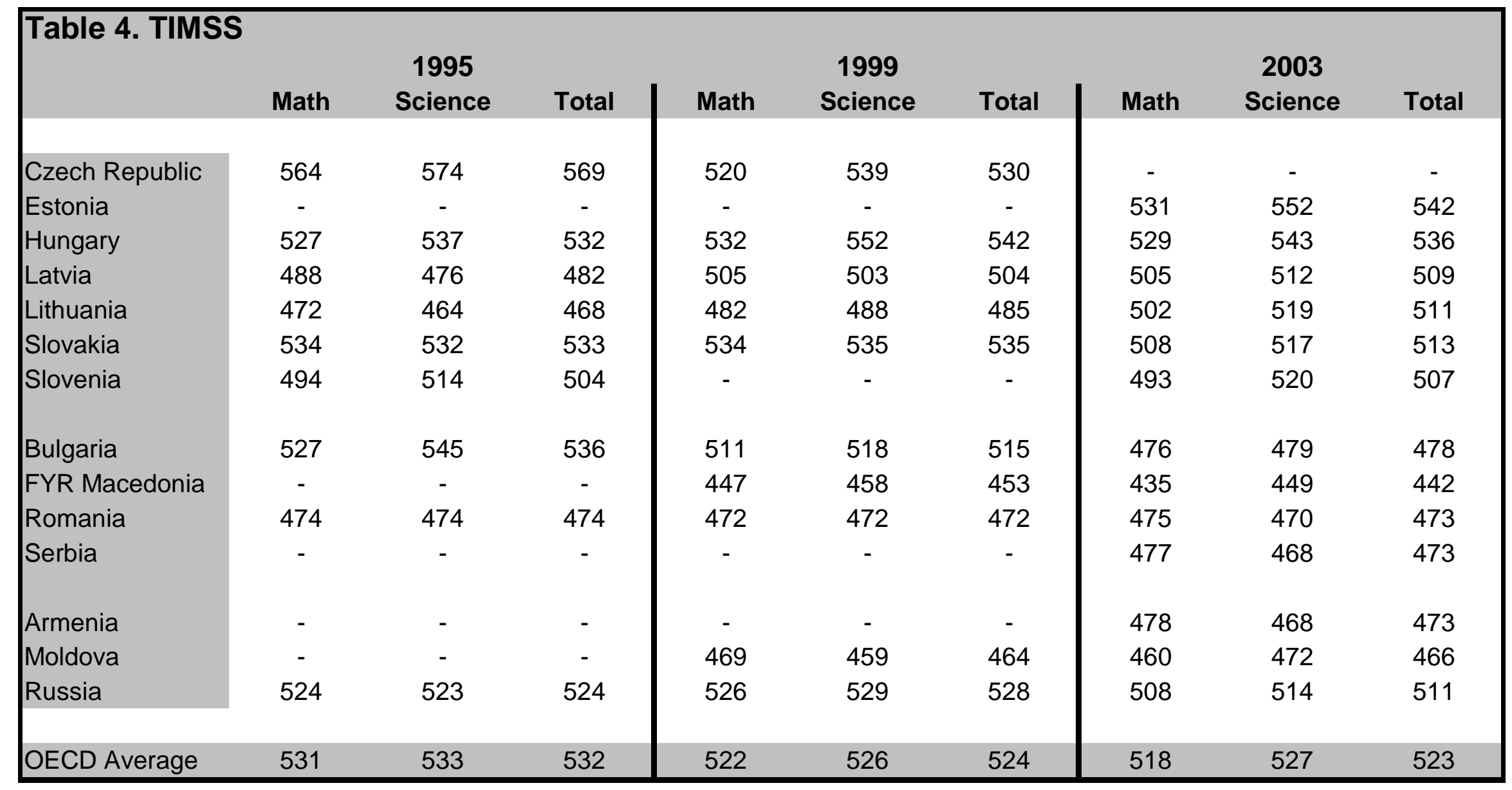

Mullis, I.V.S., M.O. Martin, E.J. Gonzalez, S.J. Chrostowski (2004), TIMSS 2003 International Science Report: Findings from IEA's Trends in International Mathematics and Science (2004). 


\begin{tabular}{|lcc|cc|cc|}
\hline \multicolumn{2}{|l}{ Table 5. TIMSS by Gender } & \multicolumn{2}{c}{ Science } & \multicolumn{2}{c|}{ Total } \\
& Male & Female & Male & Female & Male & Female \\
& & & & & & \\
Czech Republic & 528 & 512 & 557 & 523 & 543 & 518 \\
Estonia & 530 & 532 & 551 & 554 & 541 & 543 \\
Hungary & 533 & 526 & 556 & 530 & 545 & 528 \\
Latvia & 506 & 511 & 516 & 509 & 511 & 510 \\
Lithuania & 499 & 503 & 522 & 516 & 511 & 510 \\
Slovakia & 508 & 508 & 525 & 508 & 517 & 508 \\
Slovenia & 491 & 495 & 524 & 517 & 508 & 506 \\
& & & & & & \\
Bulgaria & 477 & 476 & 487 & 470 & 482 & 473 \\
FYR Macedonia & 431 & 439 & 445 & 454 & 438 & 447 \\
Romania & 473 & 477 & 474 & 465 & 474 & 471 \\
Serbia & 473 & 480 & 471 & 465 & 472 & 473 \\
& & & & & & \\
Armenia & 473 & 483 & 458 & 468 & 466 & 476 \\
Moldova & 455 & 465 & 468 & 477 & 462 & 471 \\
Russia & 507 & 510 & 519 & 508 & 513 & 509 \\
& & & & & & \\
OECD & 518 & 515 & 534 & 520 & 526 & 518 \\
United States & 507 & 502 & 536 & 519 & 522 & 511 \\
\hline
\end{tabular}

Mullis, I.V.S., M.O. Martin, E.J. Gonzalez, S.J. Chrostowski (2004), TIMSS 2003 International S Findings from IEA's Trends in International Mathematics and Science (2004). 
Figure 1

\section{TIMSS}

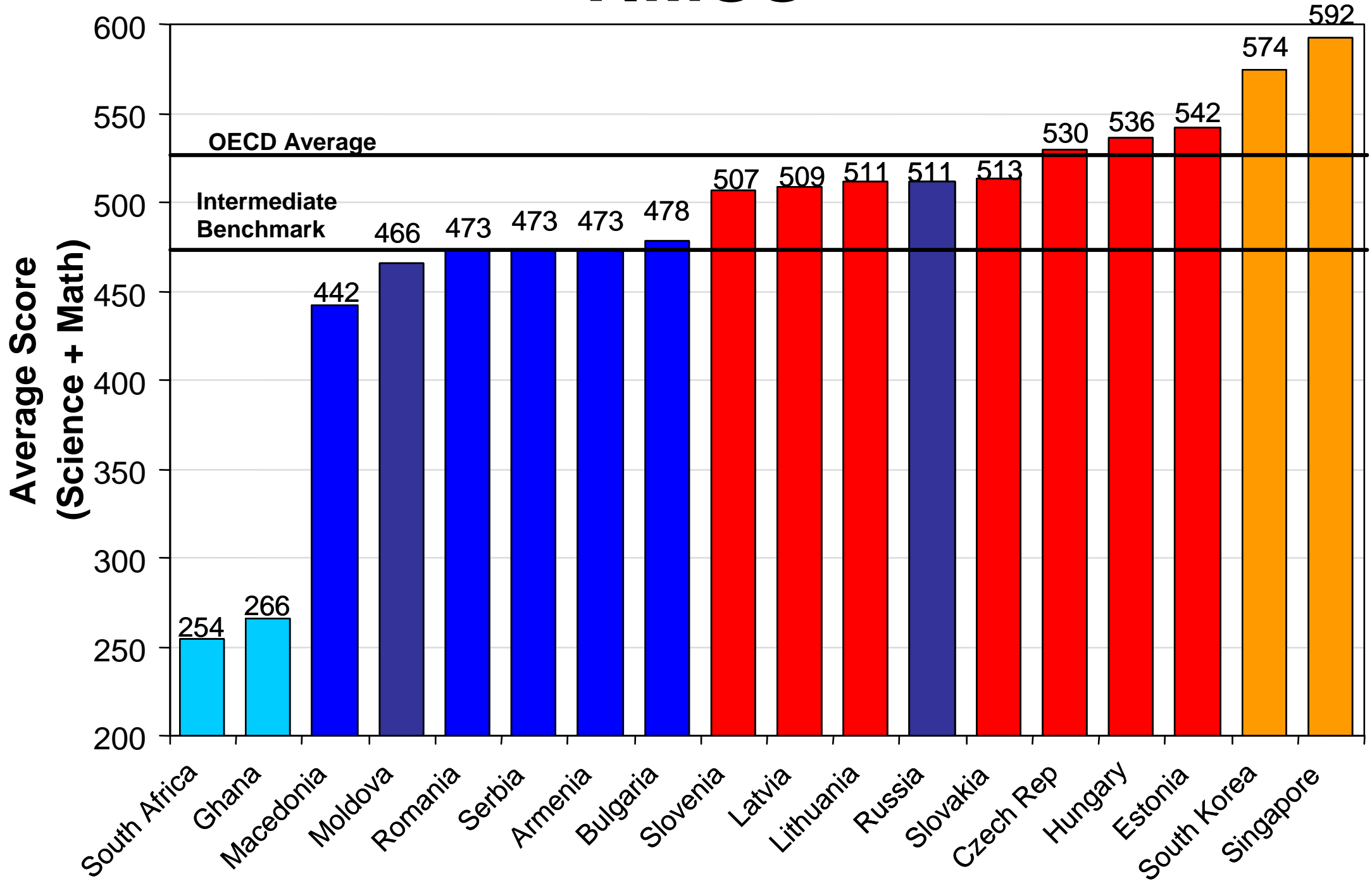

Average scale score is the average of the math and science domains. All countries use results from TIMSS 2003, except the Czech Republic which uses TIMSS 1999 results. The 2003 OECD average was 527. The intermediate international benchmark is defined as scores at or above 475 . IEA, TIMSS 2003 International Mathematics Report (2004). IEA, TIMSS 2003 International Science Report (2004). 
Figure 2

\section{TIMSS}

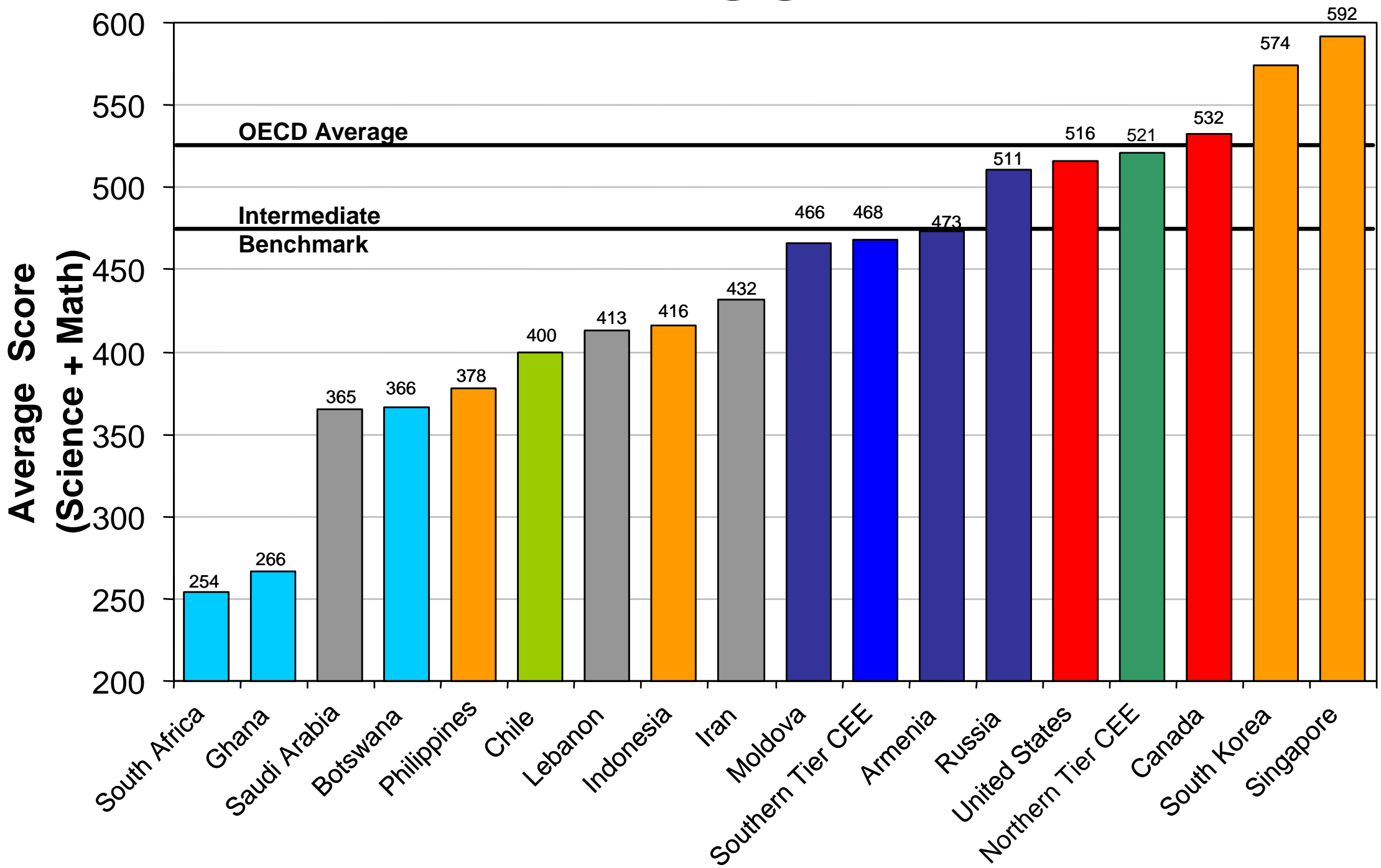

Average scale score is the average of the math and science domains. All countries use results from TIMSS 2003, except the Czech Republic (included in Northern Tier CEE average) which uses TIMSS 1999 results. The 2003 OECD average was 527 . The intermediate international benchmark is defined as students who can apply basic

mathematical knowledge in straightforward situations. IEA, TIMSS 2003 International Mathematics Report (2004). IEA, TIMSS 2003 International Science Report (2004). 
Figure 3

\section{TIMSS}

(Performance by Gender)

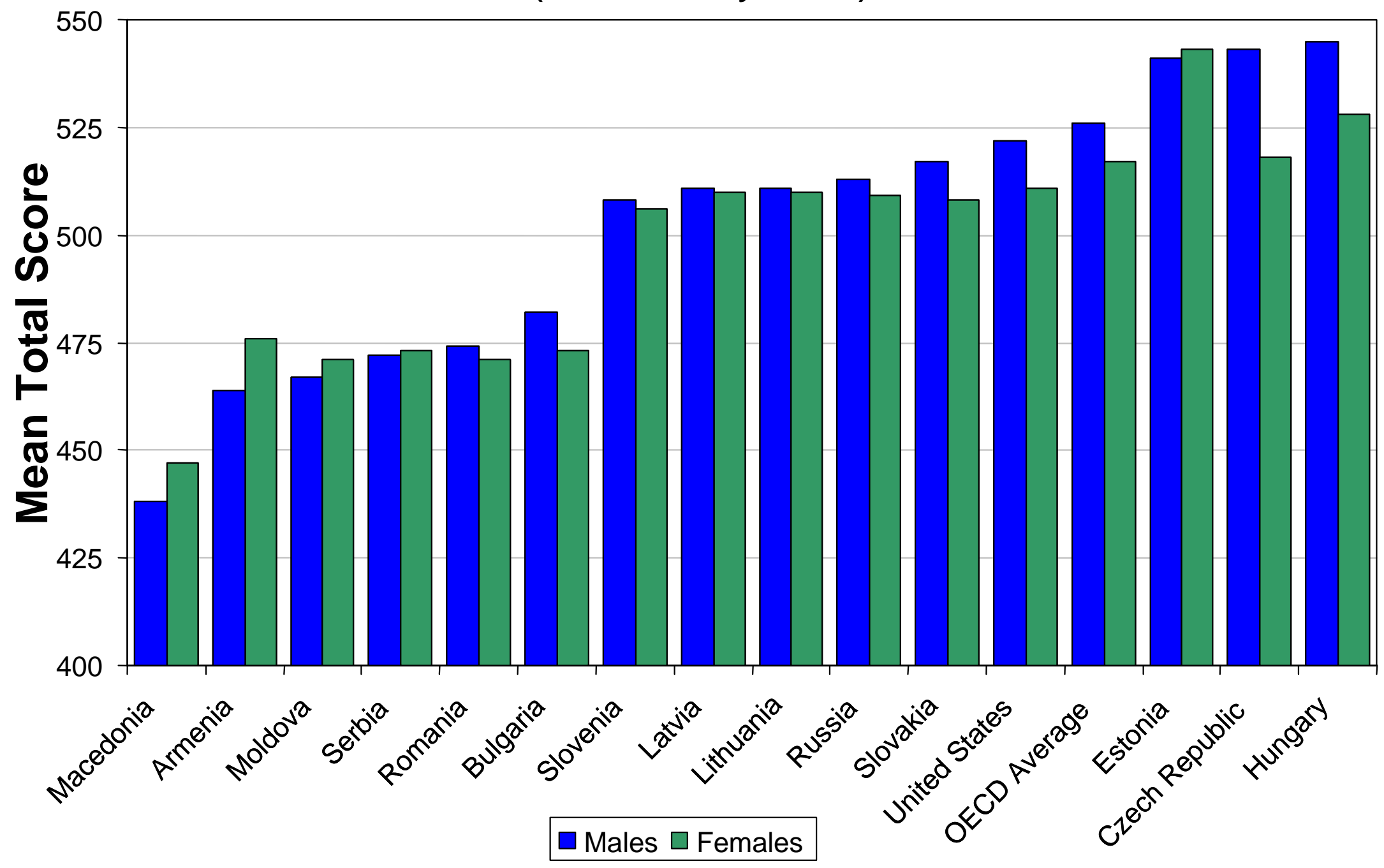

Average scale score is the average of the math and science domains. All countries use results from TIMSS 2003, except the Czech Republic which uses TIMSS 1999 results. IEA, TIMSS 2003 International Mathematics Report (2004). IEA, TIMSS 2003 International Science Report (2004). 
Figure 4

\section{TIMSS Trends}

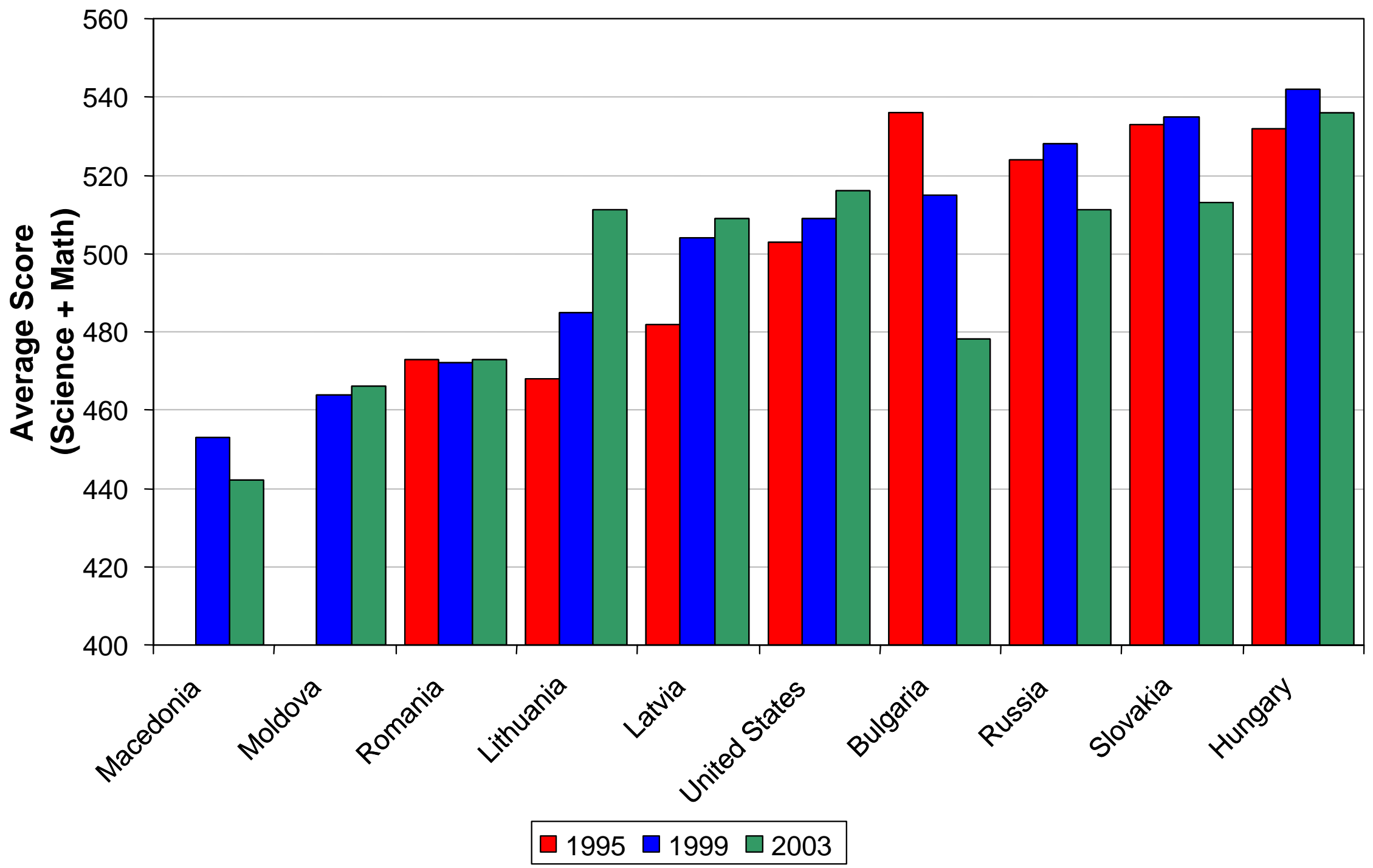

Average scale score is the average of the math and science domains. The 2003 OECD Average was 527. IEA, TIMSS 2003 International Mathematics Report (2004). IEA, TIMSS 2003 International Science Report (2004). 


\begin{tabular}{|c|c|c|c|c|c|}
\hline \multicolumn{6}{|l|}{ Table 6 IAI } \\
\hline \multicolumn{6}{|l|}{ Prose Literacy } \\
\hline & Level 1 & Level 2 & Level 3 & Level 4 & Level $3+4$ \\
\hline Poland & 42.6 & 34.5 & 19.8 & 3.1 & 22.9 \\
\hline Slovenia & 42.2 & 34.5 & 20.1 & 3.2 & 23.3 \\
\hline Hungary & 33.8 & 42.7 & 20.8 & 2.6 & 23.4 \\
\hline Czech Republic & 15.7 & 38.1 & 37.8 & 8.4 & 46.2 \\
\hline OECD Average & 19.7 & 30.3 & 35.4 & 14.5 & 49.9 \\
\hline United States & 20.7 & 25.9 & 32.4 & 21.1 & 53.5 \\
\hline \multicolumn{6}{|c|}{ Document Literacy } \\
\hline & Level 1 & Level 2 & Level 3 & Level 4 & Level $3+4$ \\
\hline Poland & 45.4 & 30.7 & 18 & 5.8 & 23.8 \\
\hline Slovenia & 40.9 & 31.8 & 22 & 5.3 & 27.3 \\
\hline Hungary & 32.9 & 34.2 & 25 & 8 & 33 \\
\hline Czech Republic & 14.3 & 28 & 38.1 & 19.6 & 57.7 \\
\hline OECD Average & 19.9 & 27.3 & 34.4 & 18.5 & 52.9 \\
\hline United States & 23.7 & 25.9 & 31.4 & 19 & 50.4 \\
\hline \multicolumn{6}{|c|}{ Quantitative Literacy } \\
\hline & Level 1 & Level 2 & Level 3 & Level 4 & Level $3+4$ \\
\hline Poland & 39.1 & 30.1 & 23.9 & 6.8 & 30.7 \\
\hline Slovenia & 35 & 30.4 & 26 & 8.6 & 34.6 \\
\hline Hungary & 20.5 & 31.6 & 31.7 & 16.1 & 47.8 \\
\hline Czech Republic & 8.9 & 22.3 & 37 & 31.9 & 68.9 \\
\hline OECD Average & 17.4 & 26 & 36 & 20.7 & 56.7 \\
\hline United States & 21 & 25.3 & 31.3 & 22.5 & 53.8 \\
\hline \multicolumn{6}{|c|}{ Total Average Literacy } \\
\hline & Level 1 & Level 2 & Level 3 & Level 4 & Level 3+4 \\
\hline Poland & 42.4 & 31.8 & 20.6 & 5.2 & 25.8 \\
\hline Slovenia & 39.4 & 32.2 & 22.7 & 5.7 & 28.4 \\
\hline Hungary & 29.1 & 36.2 & 25.8 & 8.9 & 34.7 \\
\hline Czech Republic & 13 & 29.5 & 37.6 & 20 & 57.6 \\
\hline OECD & 19 & 27.8 & 35.3 & 17.9 & 53.1 \\
\hline United States & 21.8 & 25.7 & 31.7 & 20.9 & 52.6 \\
\hline
\end{tabular}

OECD and Statistics Canada, Literacy in the Information Age: Final Report of the International Adult Literacy Survey (2000). 
Figure 5

IALS

(\% at Literacy Levels 3 \& 4 in 1994-1998)

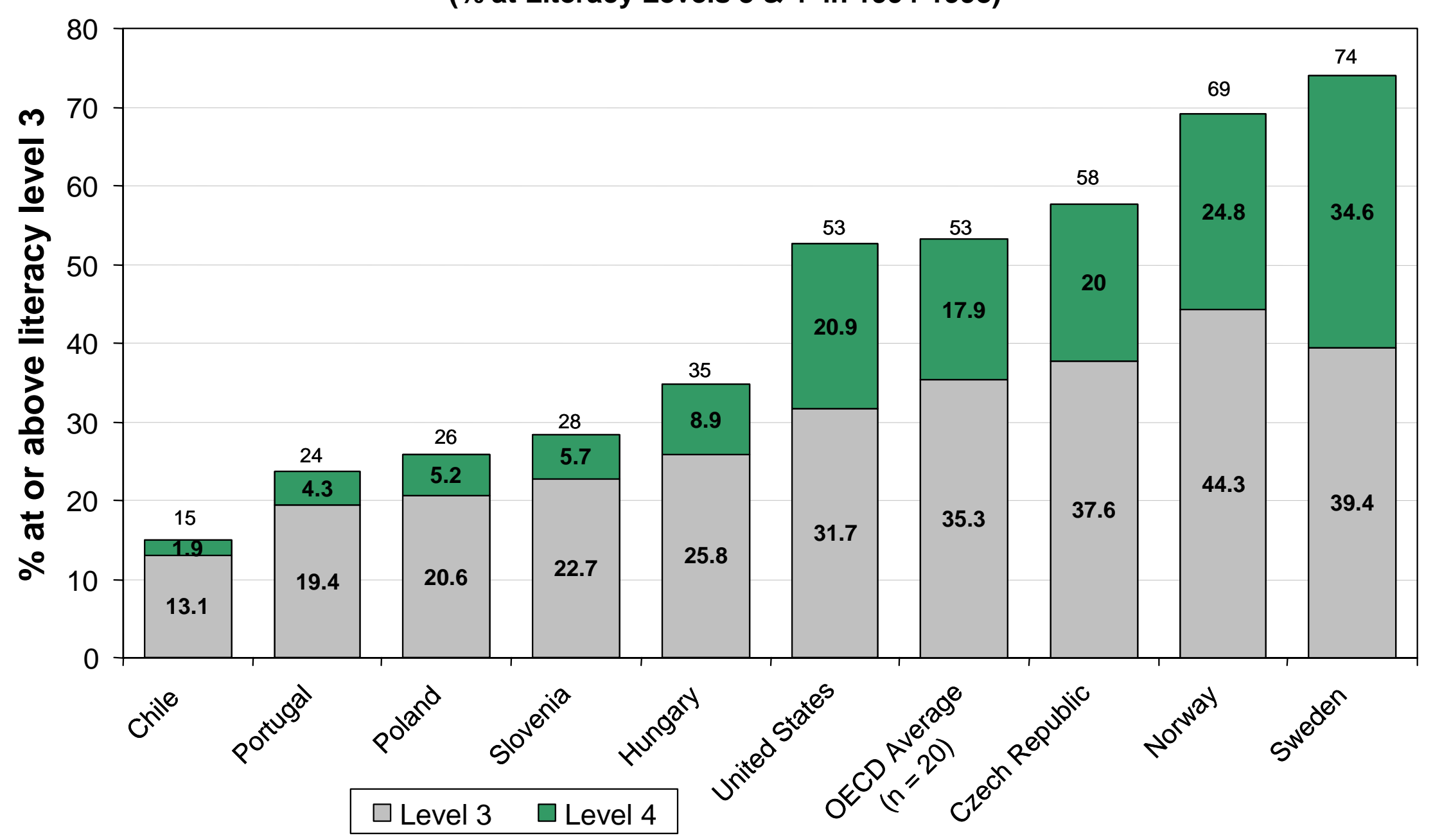

Measures the percentage of 16 to 65 year olds who test at each literacy level. Measured as the mean score all of 3 tested areas: prose literacy, document literacy, and quantitative literacy. Score of Level 3 or above denotes ability to cope with demands of complex, advanced society.

OECD, International Adult Literacy Survey (2000). 
Figure 6

\section{IALS}

(\% at Literacy Levels 3 \& 4 in 1994-1998)

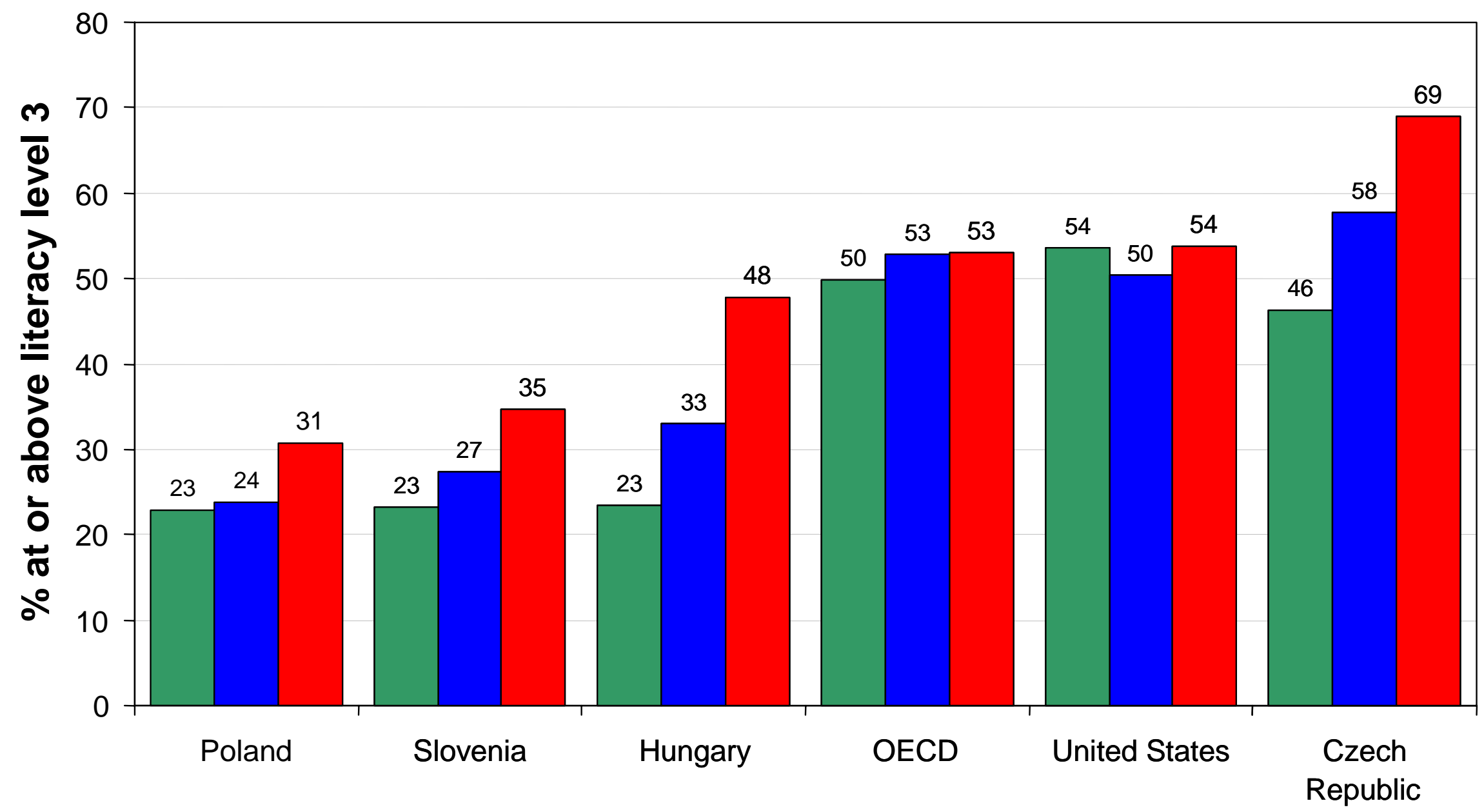

\section{Prose $\square$ Document $\square$ Quantitative}

Measures the percentage of 16 to 65 year olds who test at each literacy level. Score at or above Level 3 denotes ability to cope with demands of complex, advanced society.

OECD, International Adult Literacy Survey (2000) 


\begin{tabular}{|lcc|c|}
\hline Table 7. PIRLS & $\begin{array}{c}\text { Reading for } \\
\text { Literary Mean }\end{array}$ & $\begin{array}{c}\text { Reading for } \\
\text { Informational Mean }\end{array}$ & $\begin{array}{c}\text { Total Reading } \\
\text { Literacy Mean }\end{array}$ \\
Czech Republic & 535 & & 537 \\
Hungary & 548 & 536 & 543 \\
Latvia & 537 & 537 & 545 \\
Lithuania & 546 & 547 & 543 \\
Slovak Republic & 512 & 540 & 518 \\
Slovenia & 499 & 522 & 502 \\
Bulgaria & 550 & 503 & 550 \\
FYR Macedonia & 441 & 551 & 442 \\
Romania & 512 & 445 & 512 \\
Moldova & & 512 & 492 \\
Russia & 480 & & 528 \\
& 523 & 505 & 530 \\
OECD & - & 531 & 542 \\
United States & 550 & & - \\
\hline
\end{tabular}

Mullis, I.V.S., M.O. Martin, E.J. Gonzalez, Kennedy, Ann (2004), PIRLS 2001 International IEA's Study of Reading Literacy Achievement in Primary School in 35 Countries 
Figure 7

PIRLS

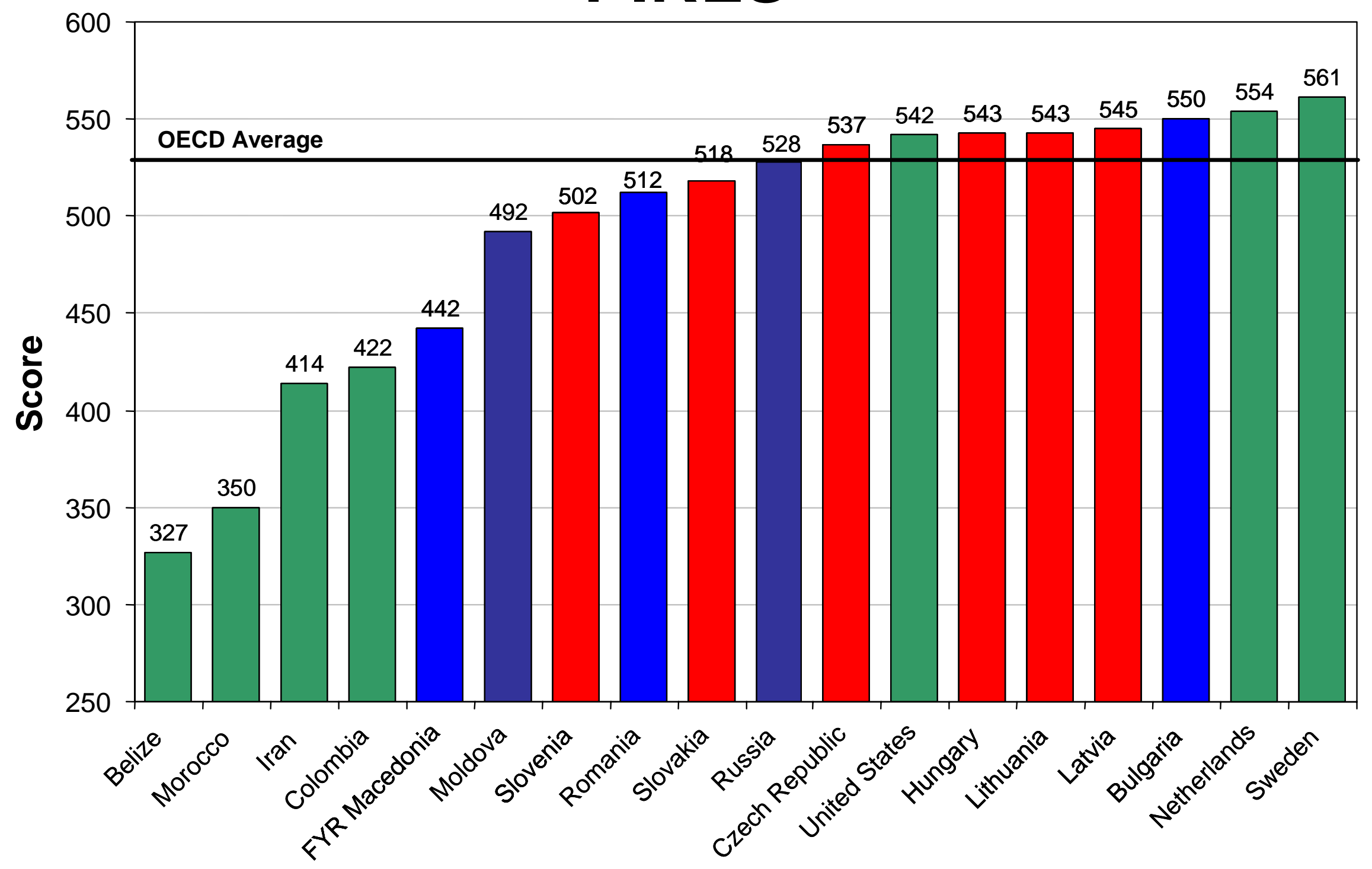

PIRLS assesses students at approximately grade 4, except Slovenia which tested students in grade 3. The OECD average was 530 . IEA, PIRLS 2001 International Report (2003). 
Figure 8

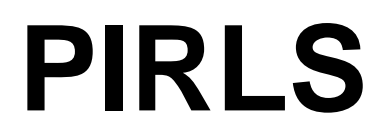

(Performance by Gender)

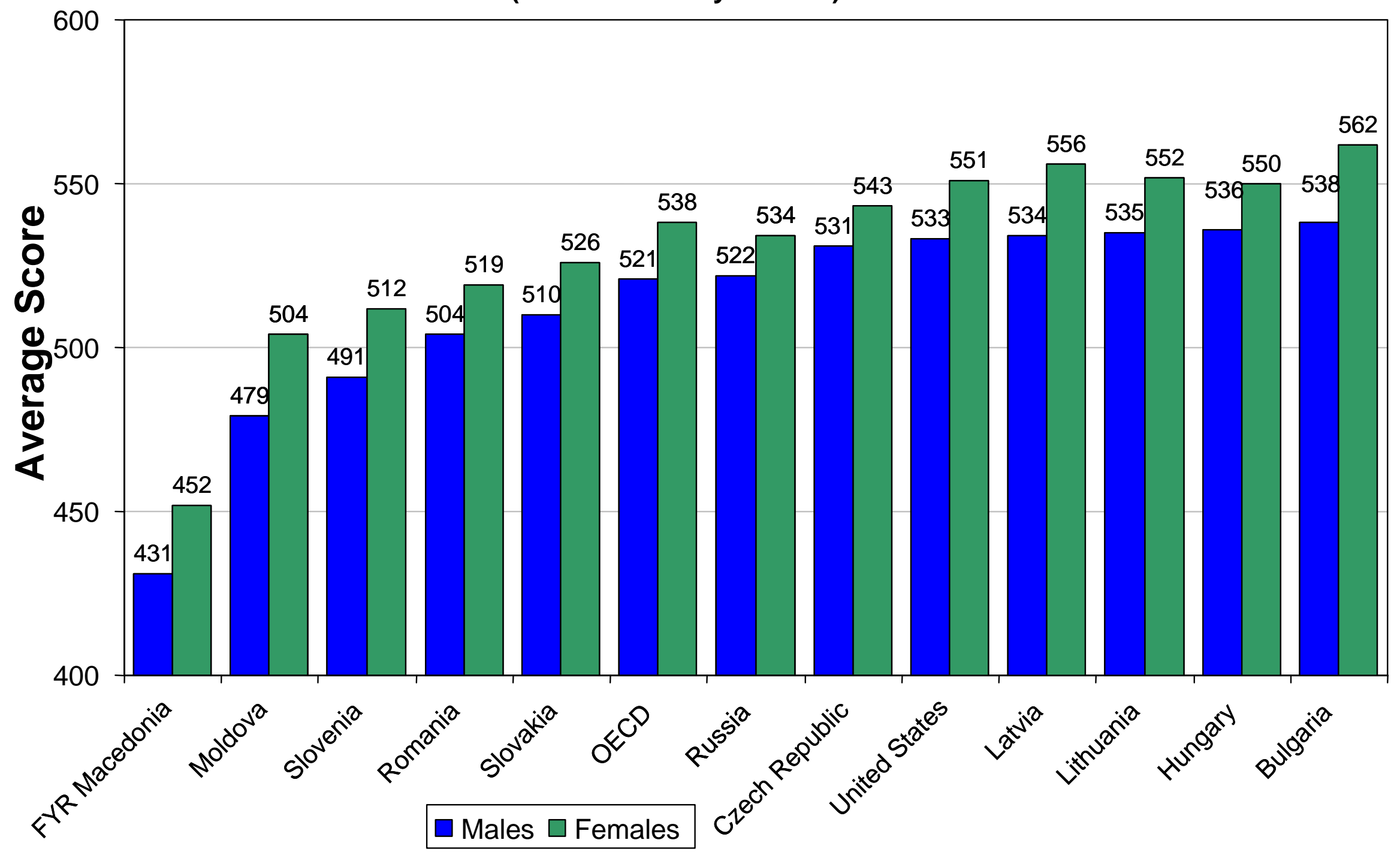

PIRLS assesses students at approximately grade 4, except Slovenia which tested students in grade 3. IEA, PIRLS 2001 International Report (2003). 


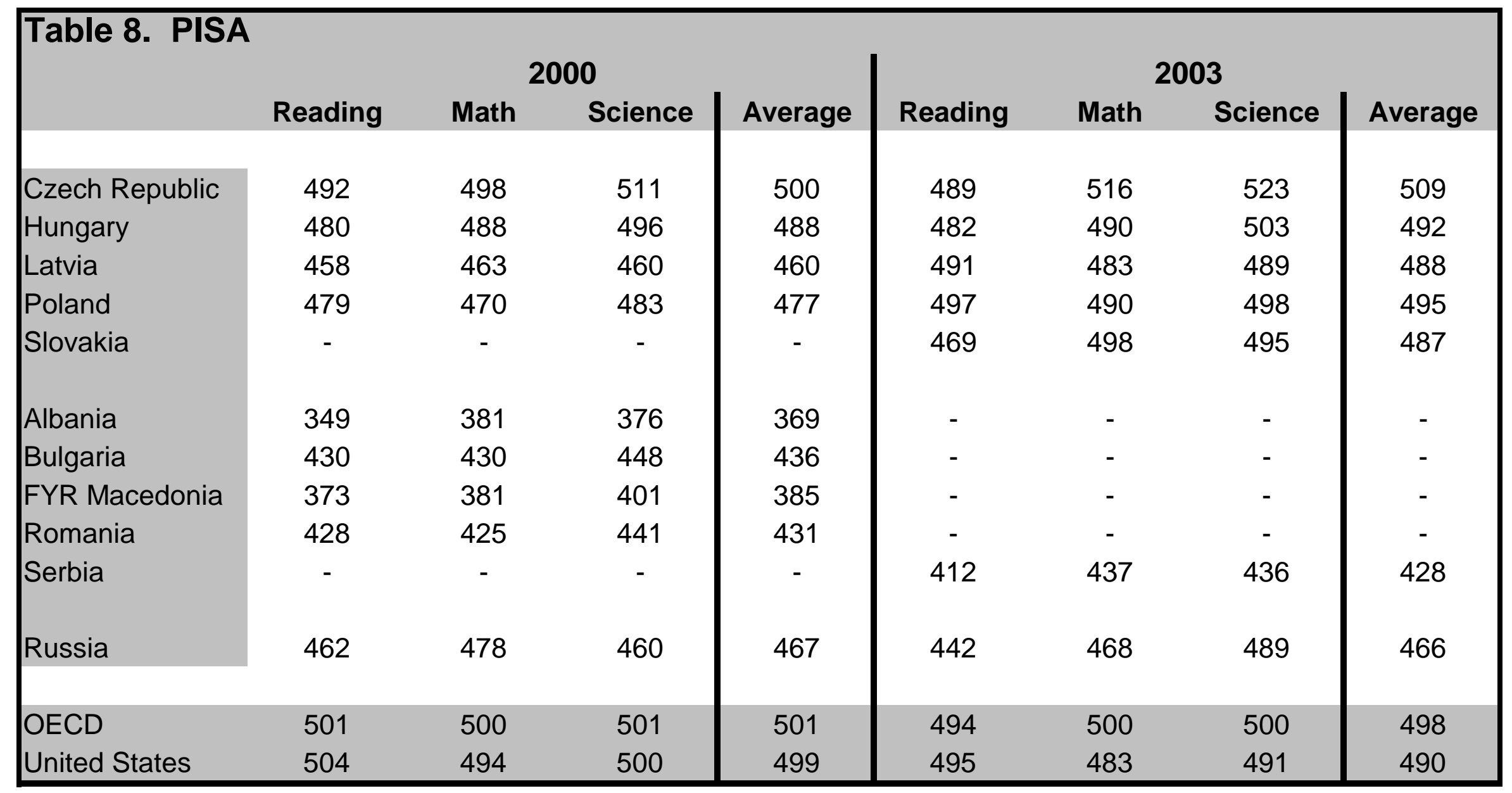

OECD, Learning for Tomorrow's World: First Results from PISA 2003 (2004). 


\begin{tabular}{|c|c|c|c|c|c|c|c|c|}
\hline \multicolumn{9}{|c|}{ Table 9. PISA by Gender } \\
\hline & \multicolumn{2}{|c|}{ Reading } & \multicolumn{2}{|c|}{ Math } & \multicolumn{2}{|c|}{ Science } & \multicolumn{2}{|c|}{ Total } \\
\hline & Male & Female & Male & Female & Male & Female & Male & Female \\
\hline Czech Republic & 473 & 504 & 524 & 509 & 526 & 520 & 508 & 511 \\
\hline Hungary & 467 & 498 & 494 & 486 & 503 & 504 & 488 & 496 \\
\hline Latvia & 470 & 509 & 483 & 485 & 487 & 491 & 480 & 495 \\
\hline Poland & 477 & 516 & 483 & 487 & 501 & 494 & 487 & 499 \\
\hline Slovakia & 453 & 486 & 507 & 489 & 502 & 487 & 487 & 487 \\
\hline Albania & 319 & 378 & 372 & 390 & 366 & 387 & 352 & 385 \\
\hline Bulgaria & 407 & 455 & 428 & 432 & 446 & 451 & 427 & 446 \\
\hline FYR Macedonia & 349 & 399 & 381 & 384 & 393 & 409 & 374 & 397 \\
\hline Romania & 421 & 434 & 420 & 430 & 434 & 448 & 425 & 437 \\
\hline Serbia & 390 & 433 & 437 & 436 & 434 & 439 & 420 & 436 \\
\hline Russia & 428 & 456 & 473 & 463 & 494 & 485 & 465 & 468 \\
\hline OECD & 485 & 517 & 506 & 495 & 501 & 501 & 497 & 504 \\
\hline United States & 479 & 511 & 486 & 480 & 494 & 489 & 486 & 493 \\
\hline
\end{tabular}

OECD, Learning for Tomorrow's World: First Results from PISA 2003 (2004). 


\begin{tabular}{|c|c|c|c|c|c|c|c|c|}
\hline \multicolumn{9}{|c|}{ Table 10. PISA by Community Size } \\
\hline & Small & Large & Small & Large & Small & Large & Small & Large \\
\hline Czech Republic & 474 & 496 & 494 & 536 & 500 & 542 & 490 & 525 \\
\hline Hungary & 434 & 491 & 413 & 505 & 425 & 517 & 424 & 502 \\
\hline Latvia & 478 & 500 & 469 & 497 & 475 & 502 & 474 & 500 \\
\hline Poland & 479 & 514 & 479 & 514 & 485 & 529 & 481 & 519 \\
\hline Slovakia & 452 & 477 & 473 & 516 & 469 & 513 & 465 & 502 \\
\hline Albania & 303 & 384 & 333 & 404 & 337 & 396 & 324 & 395 \\
\hline Bulgaria & 368 & 441 & 352 & 466 & 379 & 475 & 366 & 461 \\
\hline FYR Macedonia & 380 & 371 & 396 & 382 & 418 & 402 & 398 & 385 \\
\hline Romania & 371 & 446 & 406 & 444 & 420 & 457 & 399 & 449 \\
\hline Serbia & 386 & 415 & 411 & 444 & 410 & 445 & 402 & 435 \\
\hline Russia & 416 & 454 & 444 & 483 & 465 & 503 & 442 & 480 \\
\hline OECD & 483 & 500 & 487 & 507 & 484 & 509 & 484 & 505 \\
\hline United States & 503 & 496 & 489 & 471 & 501 & 478 & 497 & 482 \\
\hline
\end{tabular}

OECD, Learning for Tomorrow's World: First Results from PISA 2003 (2004). 


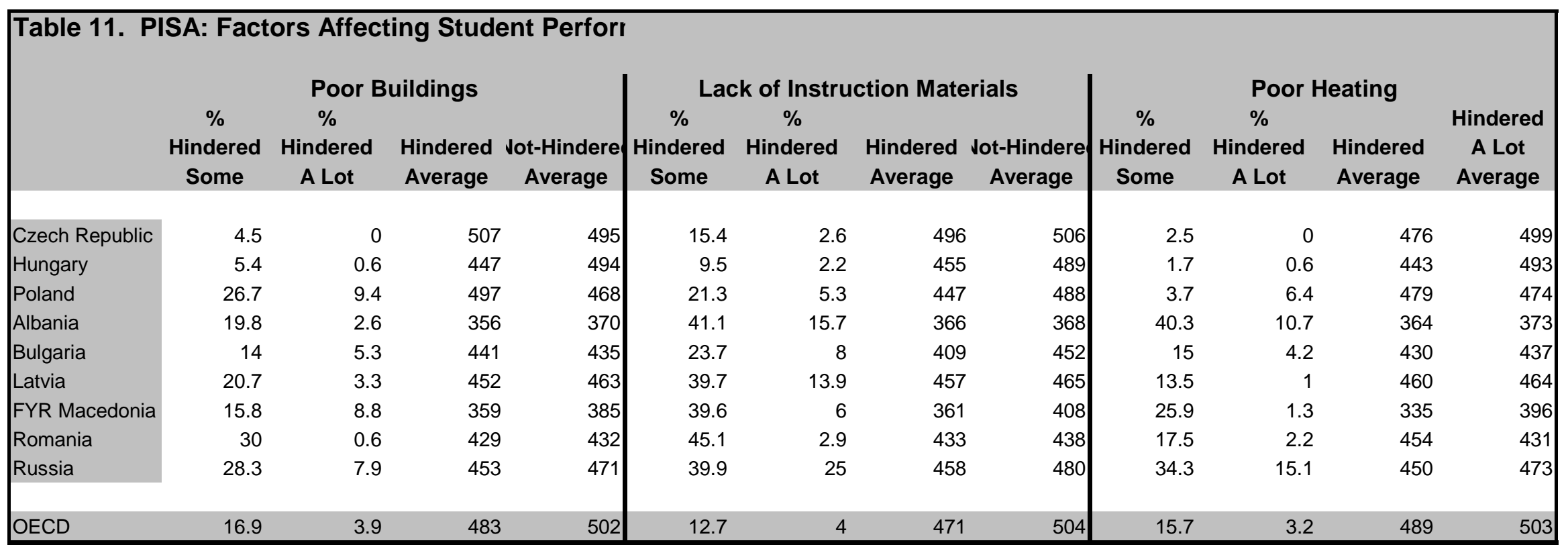

OECD, Learning for Tomorrow's World: First Results from PISA 2003 (2004). 
Figure 9

PISA

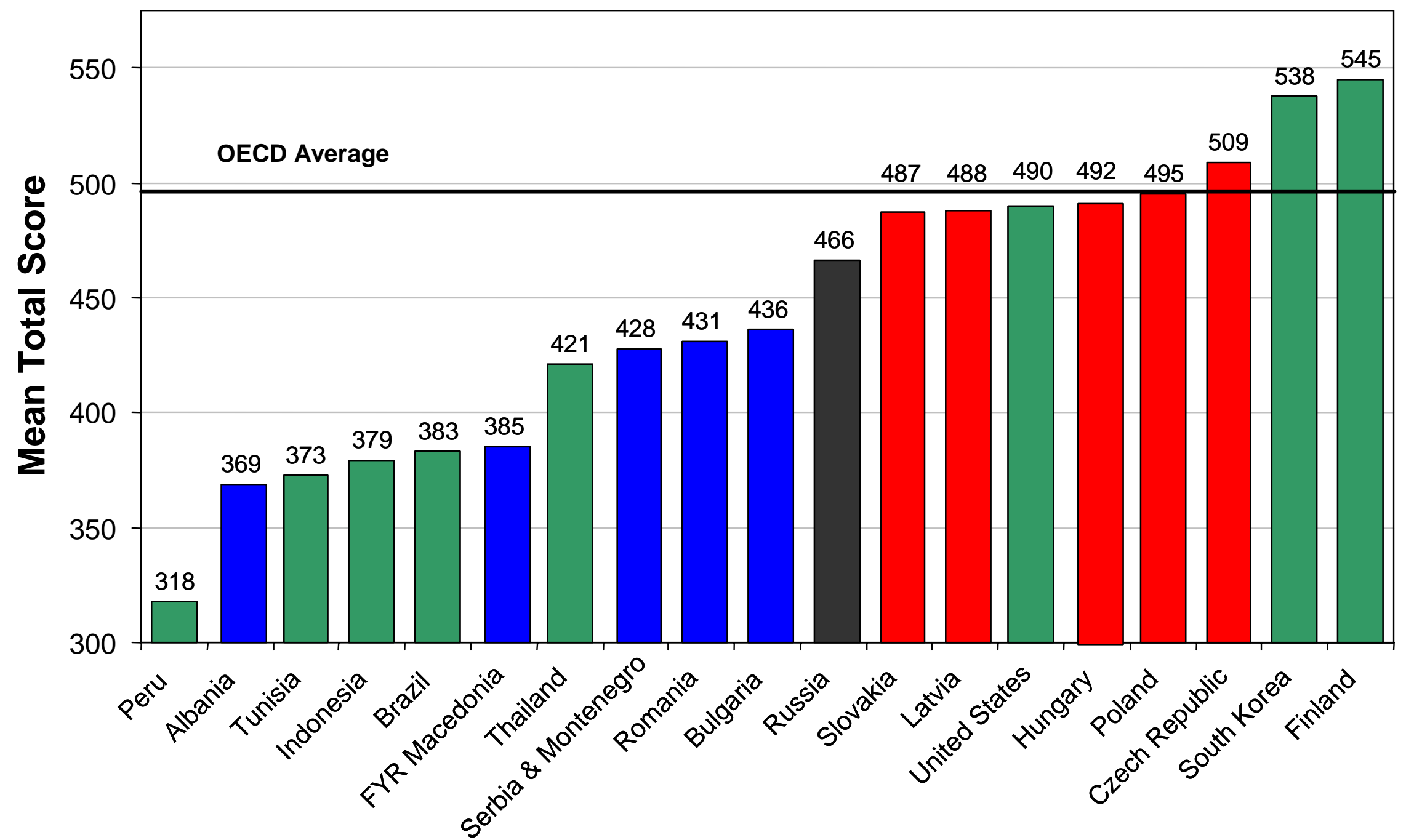

Mean total score is the average of the reading, math, and science domains. Results taken from most recently administered assessment available. Albania, FYR Macedonia, Romania, and Bulgaria use PISA 2000; Serbia \& Montenegro, Russia, Slovakia, Latvia, Hungary, Poland, Czech Republic, the OECD, and all non-E\&E, excepting Peru, countries use PISA 2003.

OECD, Literacy Skills for the World of Tomorrow: Further Results from PISA 2000 (2003). OECD, Learning for Tomorrow's World: First Results from PISA 2003 (2004). 
Figure 10

PISA

(Performance by Domain)

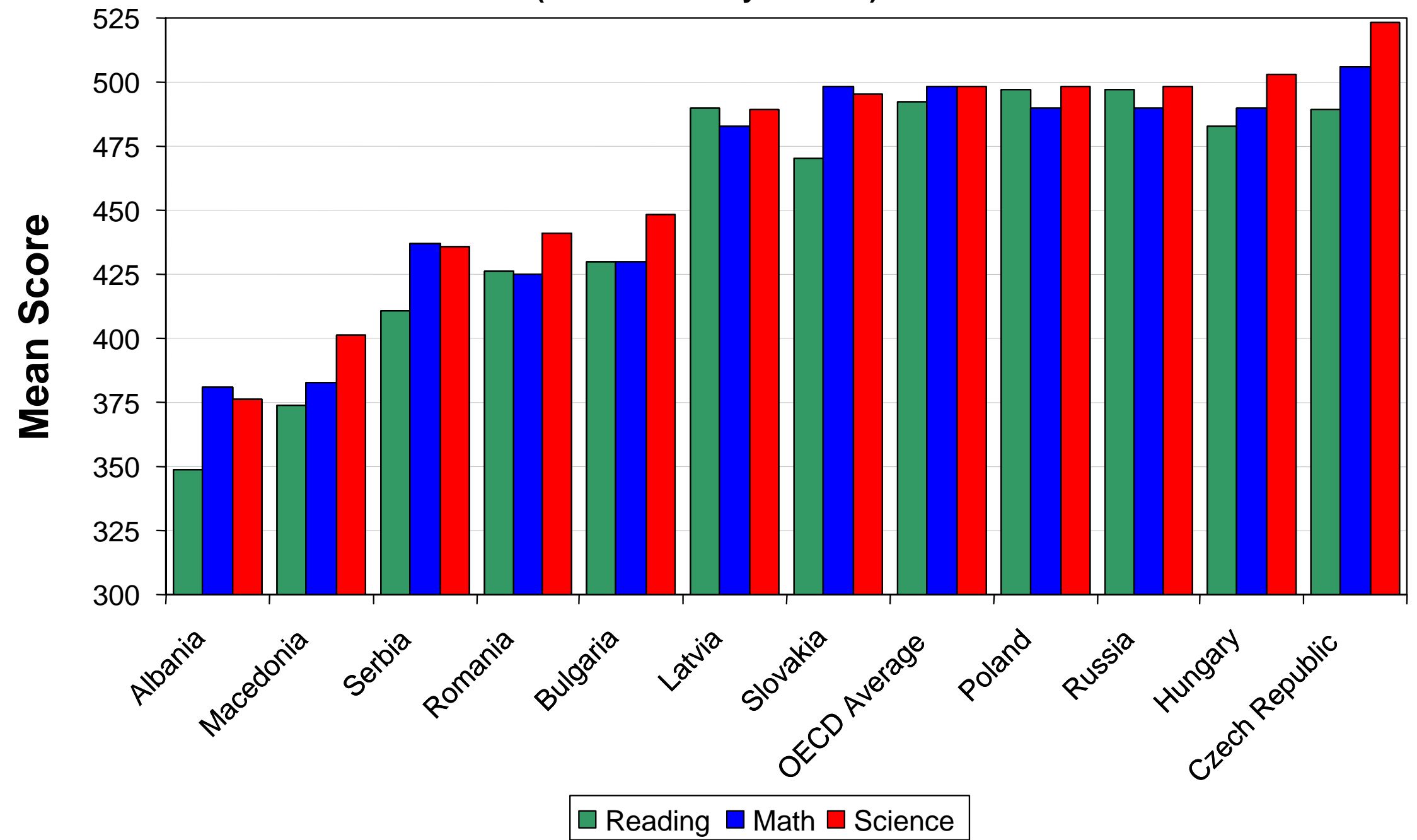

Results taken from most recently administered assessment available. Albania, FYR Macedonia, Romania, and Bulgaria use PISA 2000; Serbia \& Montenegro, Russia, Slovakia, Latvia, Hungary, Poland, Czech Republic, and the OECD countries use PISA 2003.

OECD, Literacy Skills for the World of Tomorrow: Further Results from PISA 2000 (2003). OECD, Learning for Tomorrow's World: First Results from PISA 2003 (2004). 
Figure 11

PISA

(Performance by Gender)

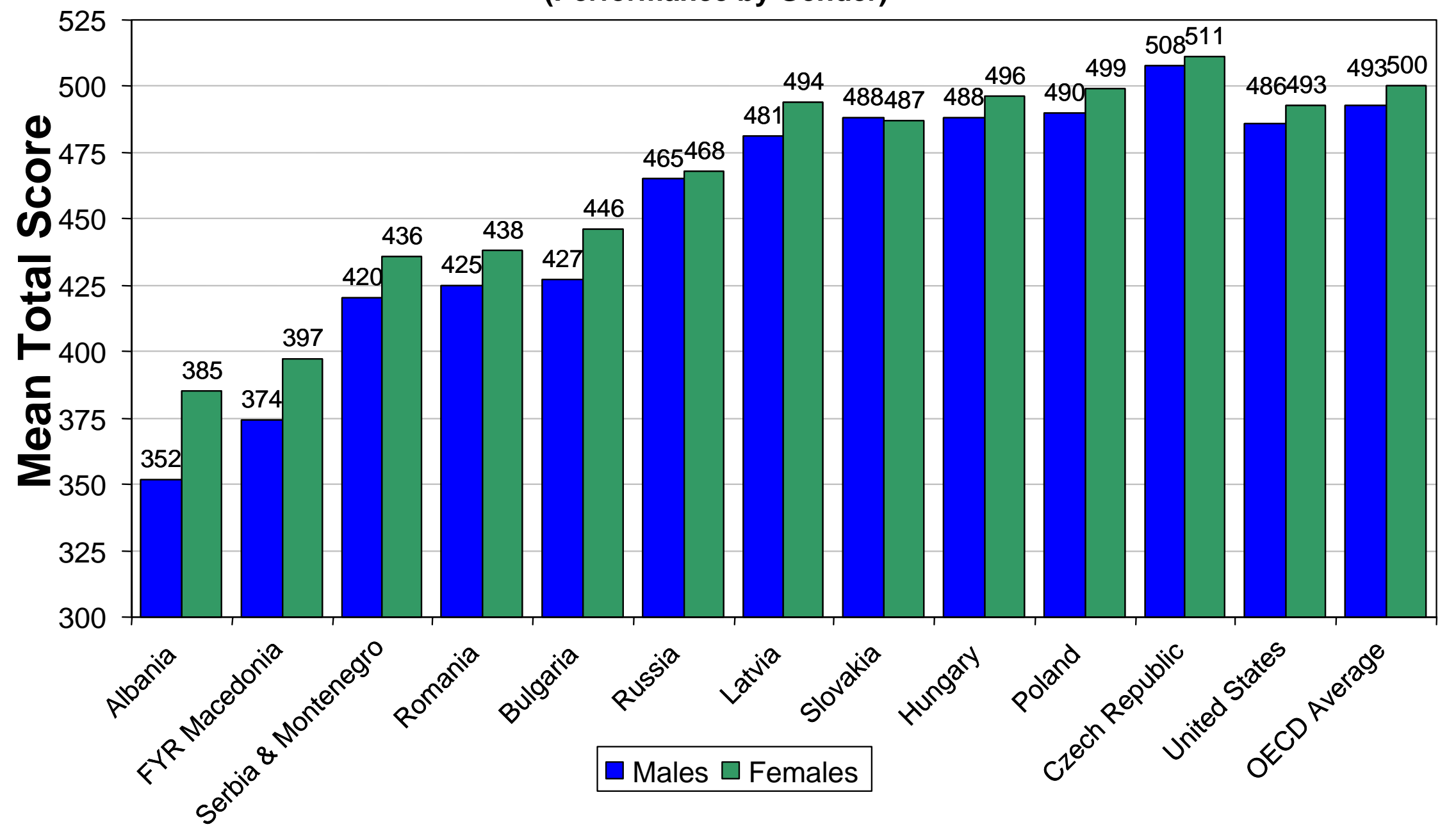

Mean total score is the average of the reading, math, and science domains. Results taken from most recently administered assessment available. Albania, FYR Macedonia, Romania, and Bulgaria use PISA 2000; Serbia \& Montenegro, Russia, Slovakia, Latvia, Hungary, Poland, Czech Republic, the OECD, and all non-E\&E countries use PISA 2003.

OECD, Literacy Skills for the World of Tomorrow: Further Results from PISA 2000 (2003). OECD, Learning for Tomorrow's World: First Results from PISA 2003 (2004). 
Figure 12

PISA

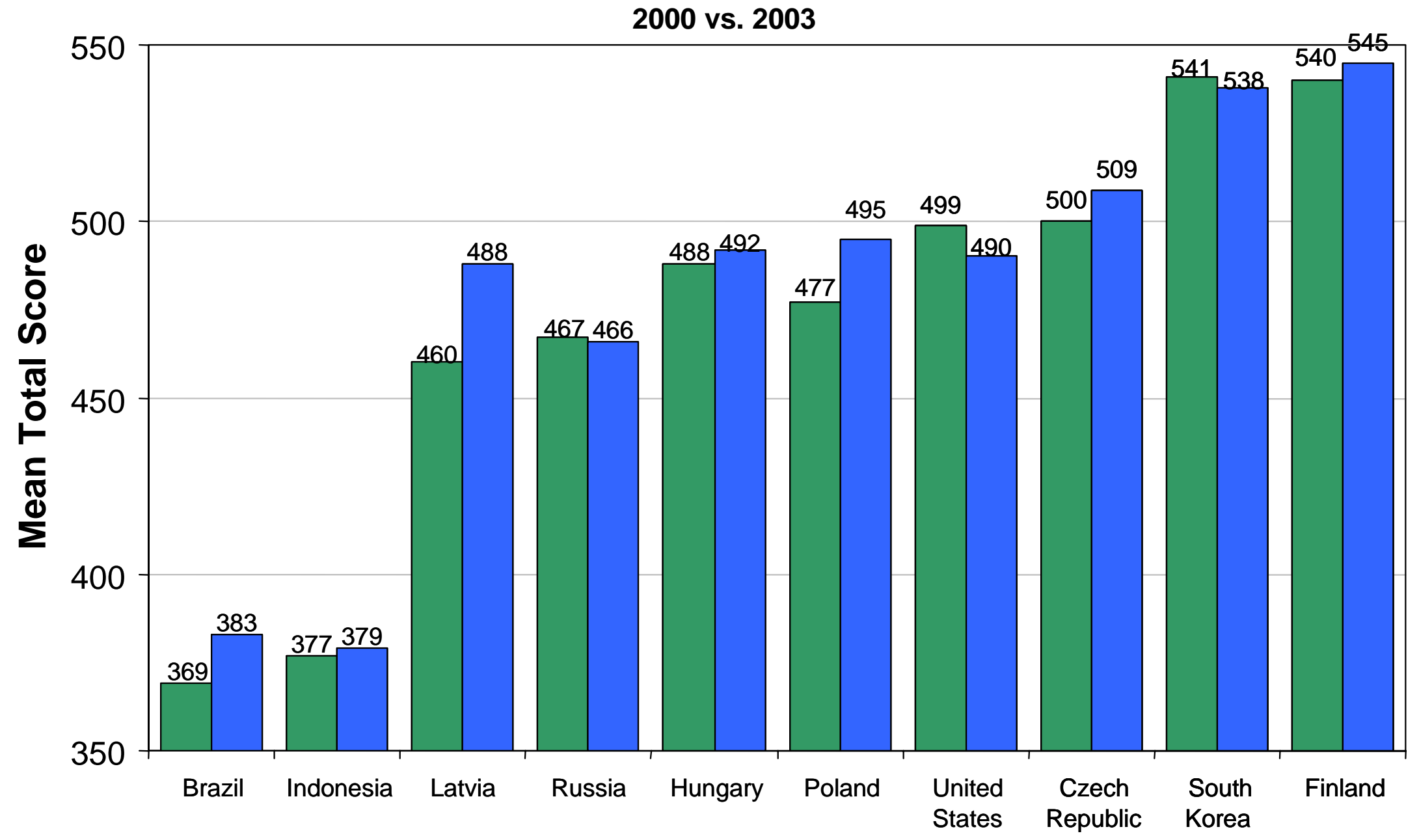

\section{$2000 \square 2003$}

Mean total score is the average of scores on the reading, math, and science domains.

OECD, Literacy Skills for the World of Tomorrow: Further Results from PISA 2000 (2003). OECD, Learning for Tomorrow's World: First Results from PISA 2003 (2004). 
Figure 13

PISA

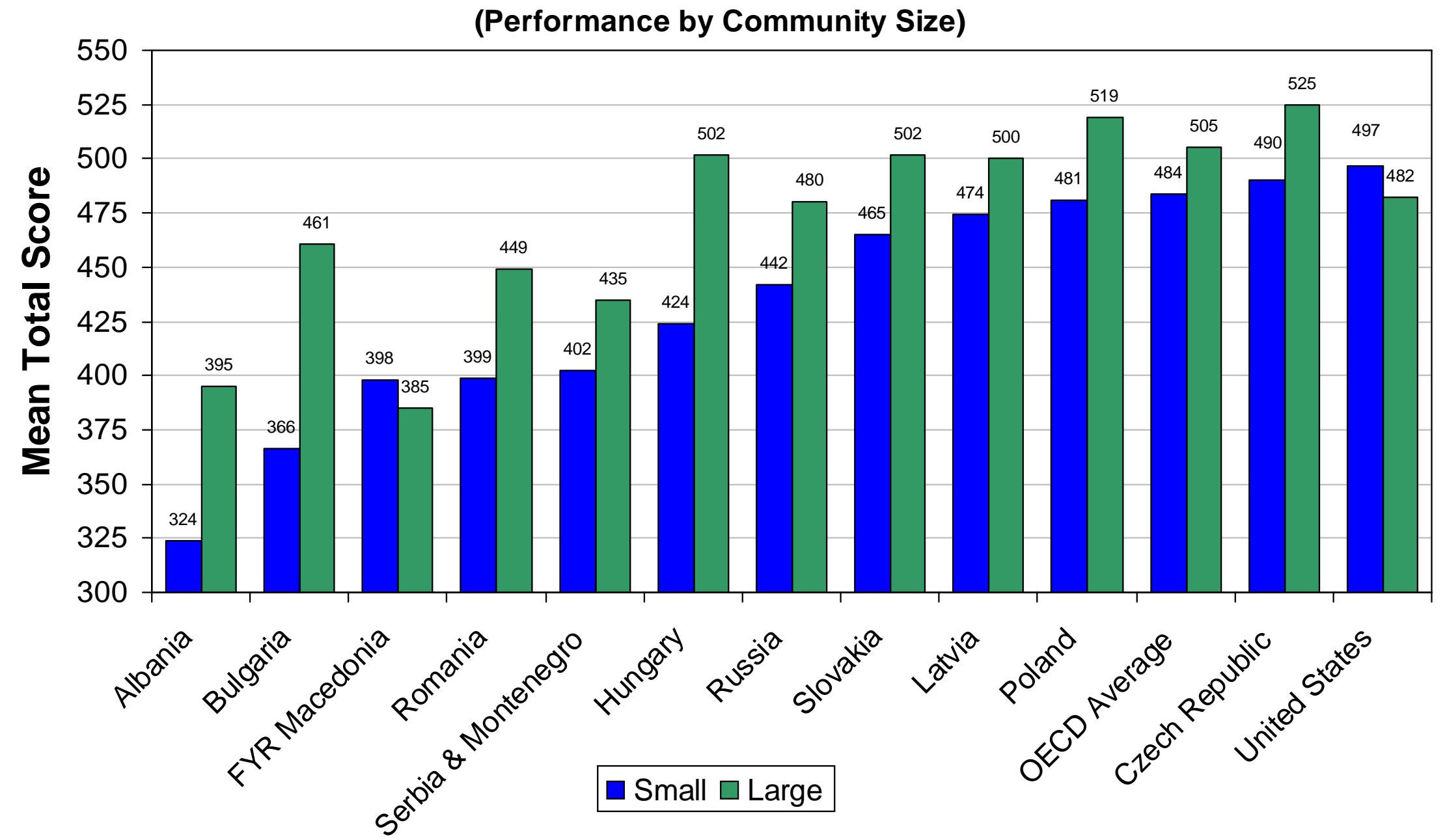

Small community defined by population less than 15,000; Large community defined by population more than 15,000. Mean total score is the average of the reading, math, and science domains. Results taken from most recently administered assessment available. Albania, FYR Macedonia, Romania, and Bulgaria use PISA 2000; Serbia \& Montenegro, Russia, Slovakia, Latvia, Hungary, Poland, Czech Republic, the OECD, and all the US countries use PISA 2003.

OECD, Literacy Skills for the World of Tomorrow: Further Results from PISA 2000 (2003). OECD, Learning for Tomorrow's World: First Results from PISA 2003 (2004). 
Figure 14

PISA

(\% Students Hindered by Poor Heating, Cooling, and/or lighting systems)

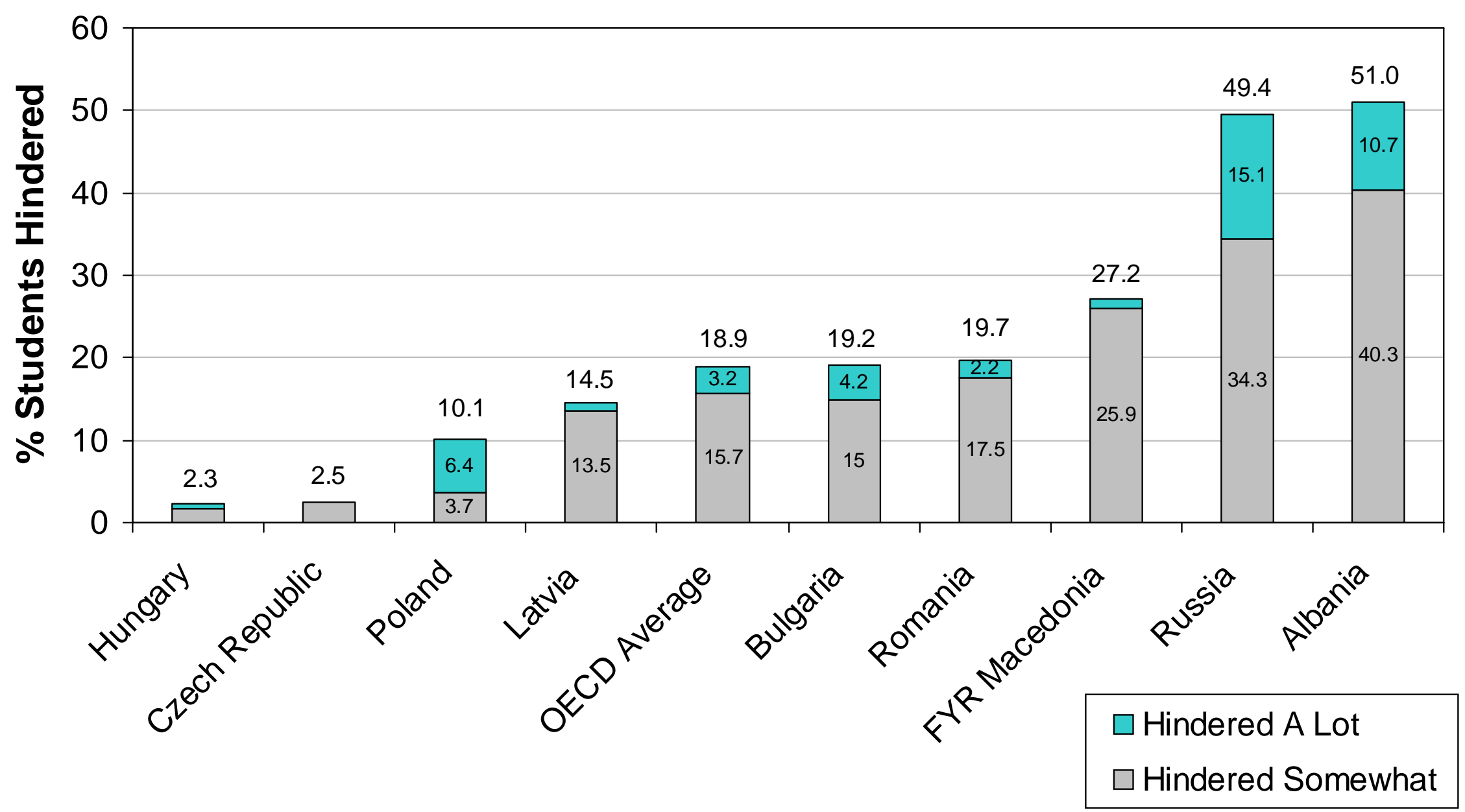

Data collected from school questionnaire distributed in conjunction with student assessment. Schools asked the question: "In your school, how much is the learning of 15-yearold-students hindered by poor heating, cooling, and/or lighting systems?"

OECD, Learning for Tomorrow's World: First Results from PISA 2003 (2004). Data generated from http://pisaweb.acer.edu.au/oecd/oecd_pisa_data.html. 
Figure 15

\section{PISA}

(Performance by Adequacy of Heating/Cooling/Lighting Systems)

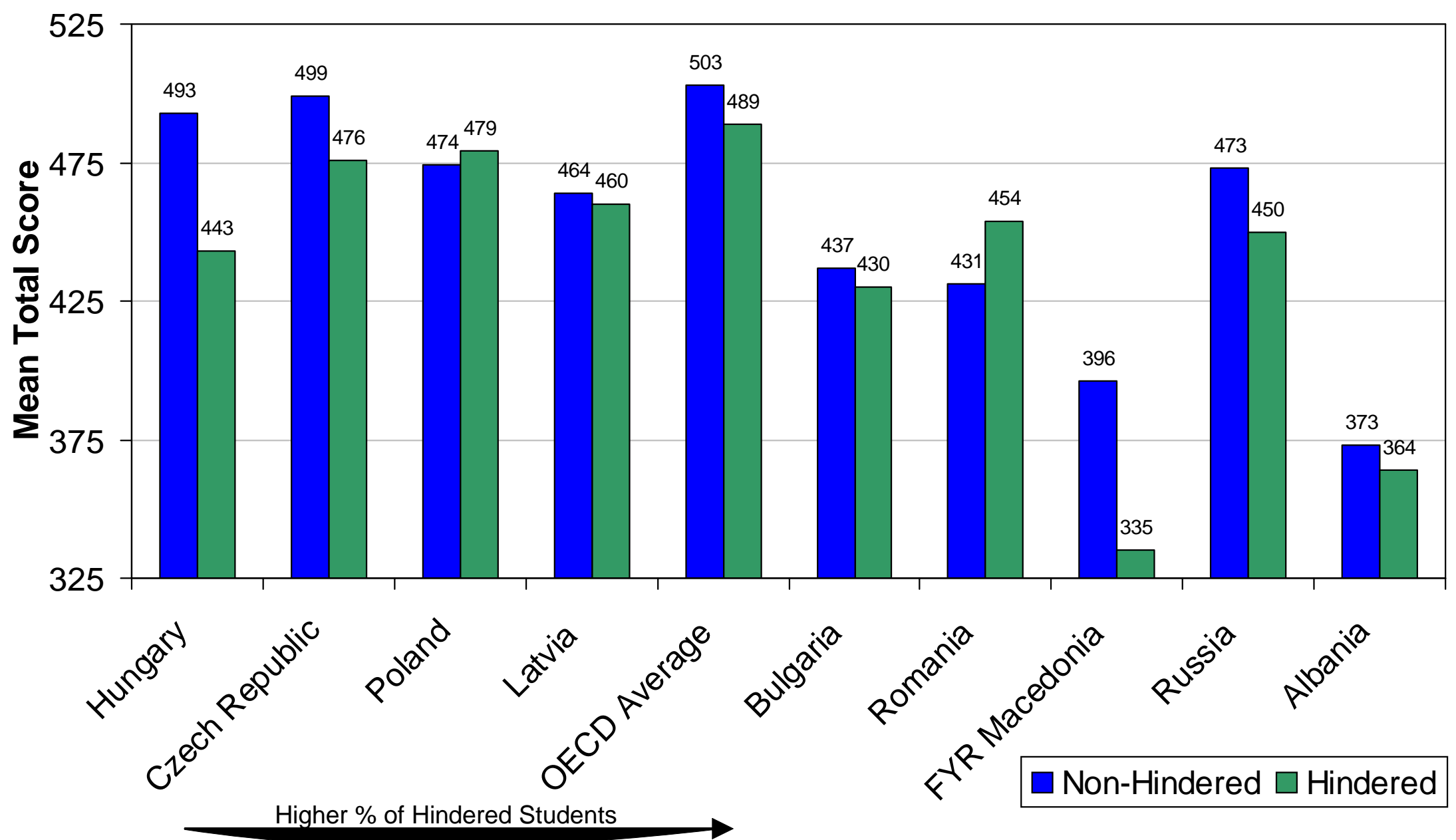

Non-hindered includes students where, according to school surveys, learning is affected by poor heating/cooling/lighting systems either not at all or a little; hindered includes those students where learning is affected either some or a lot. OECD, Learning for Tomorrow's World: First Results from PISA 2003 (2004). Data generated from http://pisaweb.acer.edu.au/oecd/oecd_pisa_data.html. 
Figure 16

\section{PISA}

(\% Students Hindered by Lack of Instruction Materials)

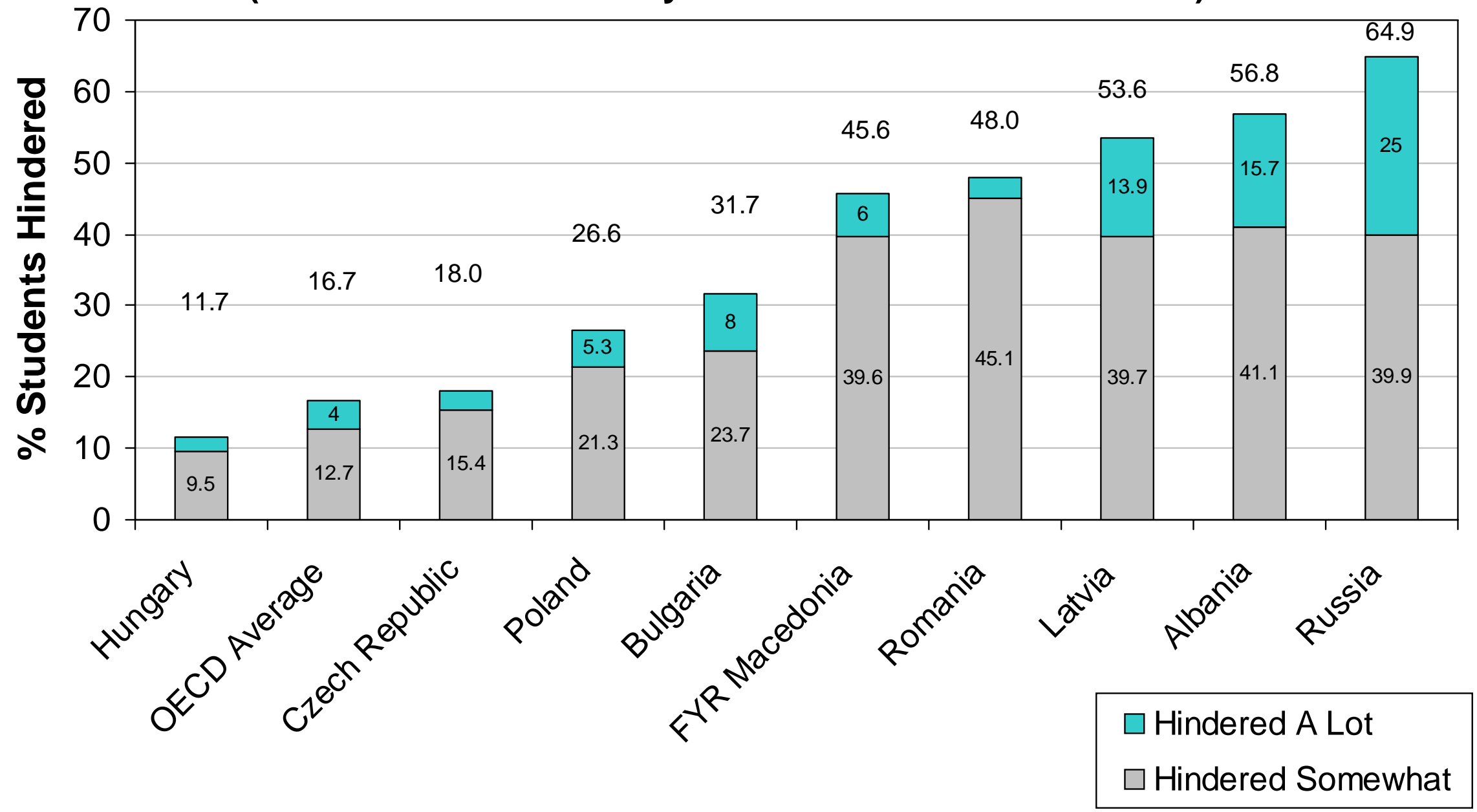

Data collected from school questionnaire distributed in conjunction with student assessment. Schools asked the question: "In your school, how much is the learning of 15-yearold-students hindered by lack of instructional material (e.g. textbooks)?"

OECD, Learning for Tomorrow's World: First Results from PISA 2003 (2004). Data generated from http://pisaweb.acer.edu.au/oecd/oecd_pisa_data.html. 
Figure 17

\section{PISA}

(Performance by Adequacy of Insructional Materials)

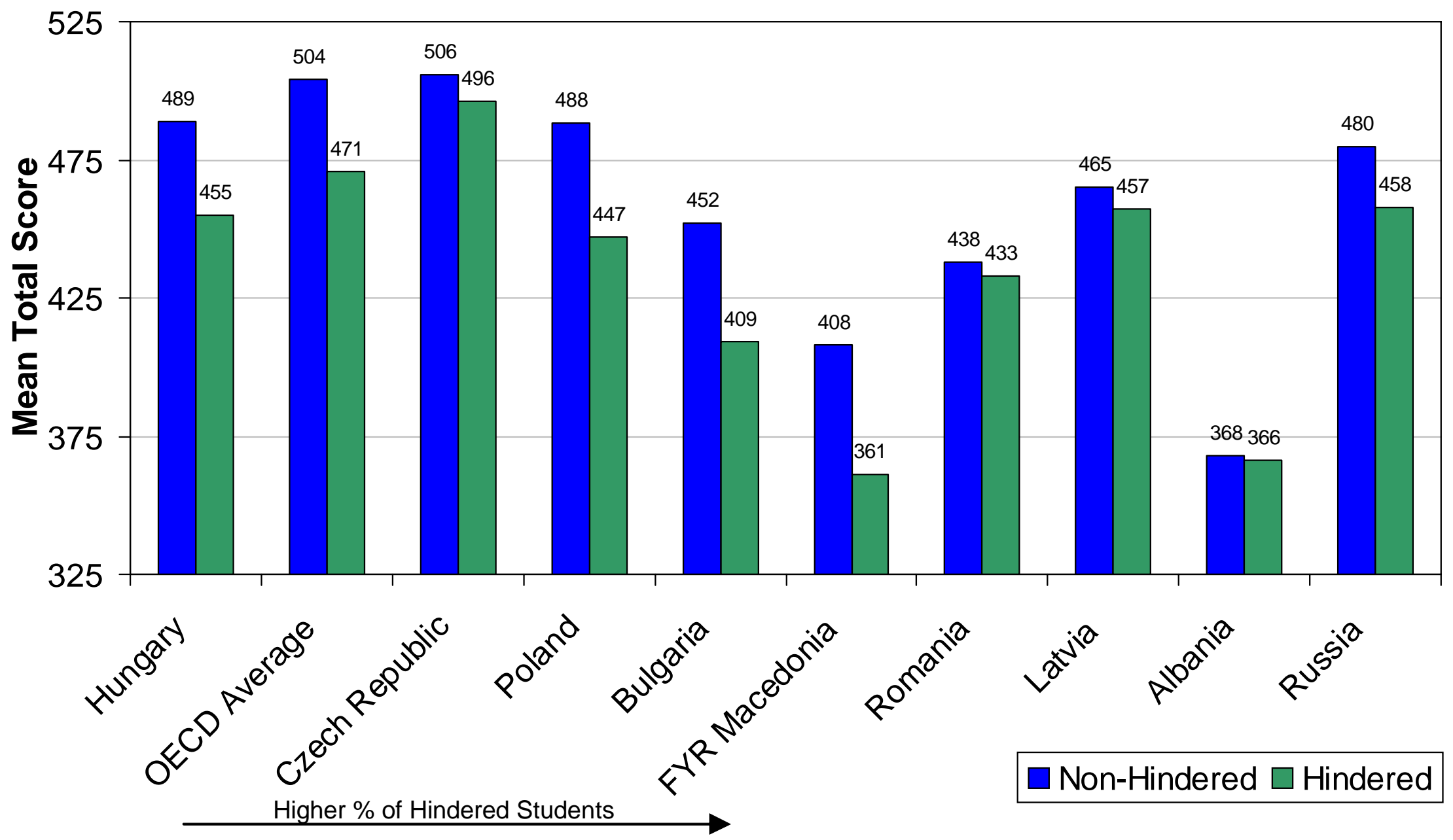

Non-hindered includes students where, according to school surveys, learning is affected by instructional material inadequacies either not at all or a little; hindered includes those students where learning is affected either some or a lot. OECD, Learning for Tomorrow's World: First Results from PISA 2003 (2004). Data generated from http://pisaweb.acer.edu.au/oecd/oecd_pisa_data.html. 
Figure 18

PISA vs. IALS

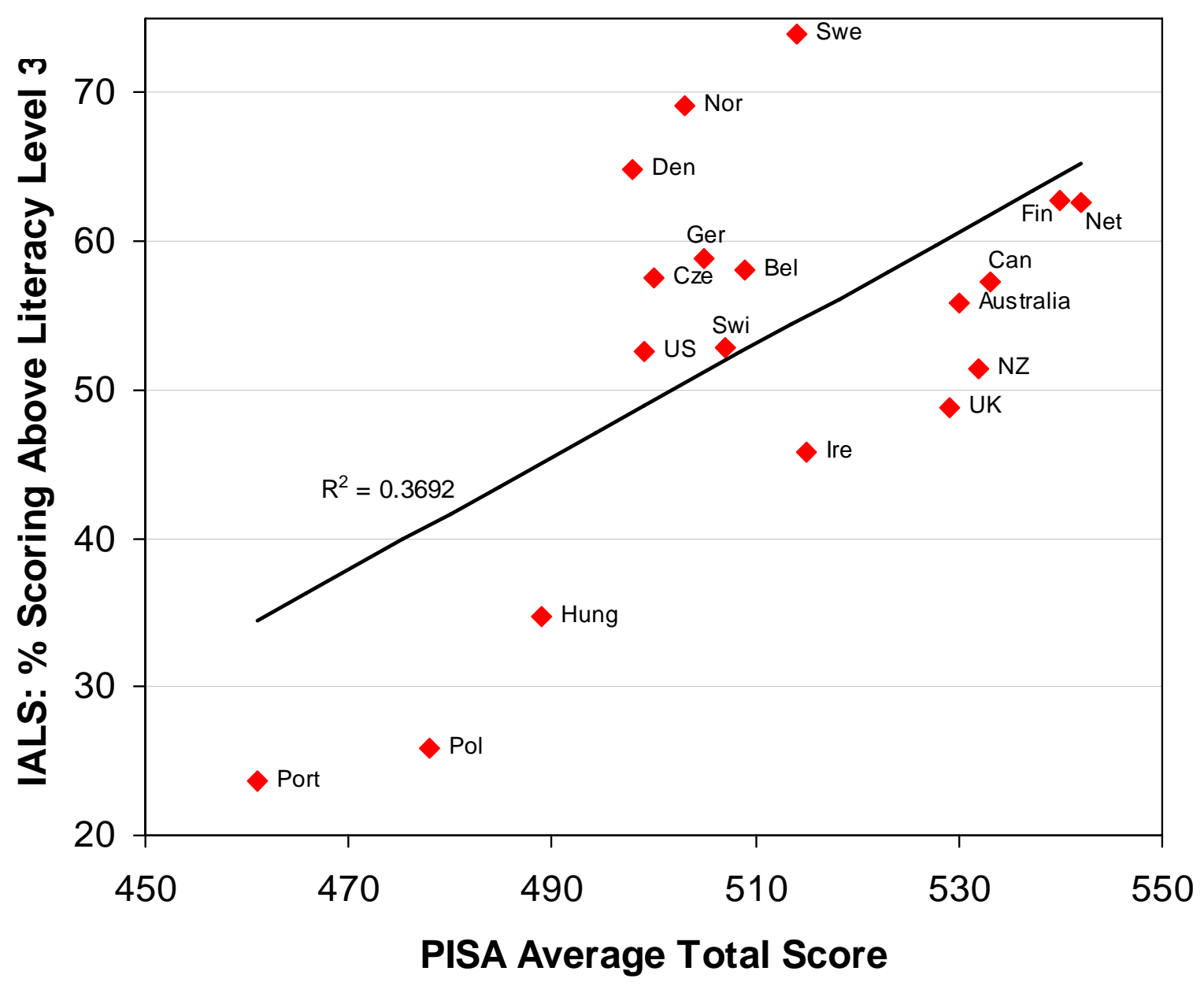

OECD, Literacy Skills for the World of Tomorrow: Further Results from PISA 2000 (2003). OECD, First Results from PISA 2003 (2004). OECD, International Adult Literacy Survey (2000). 
Figure 19

\section{PISA vs. TIMSS}

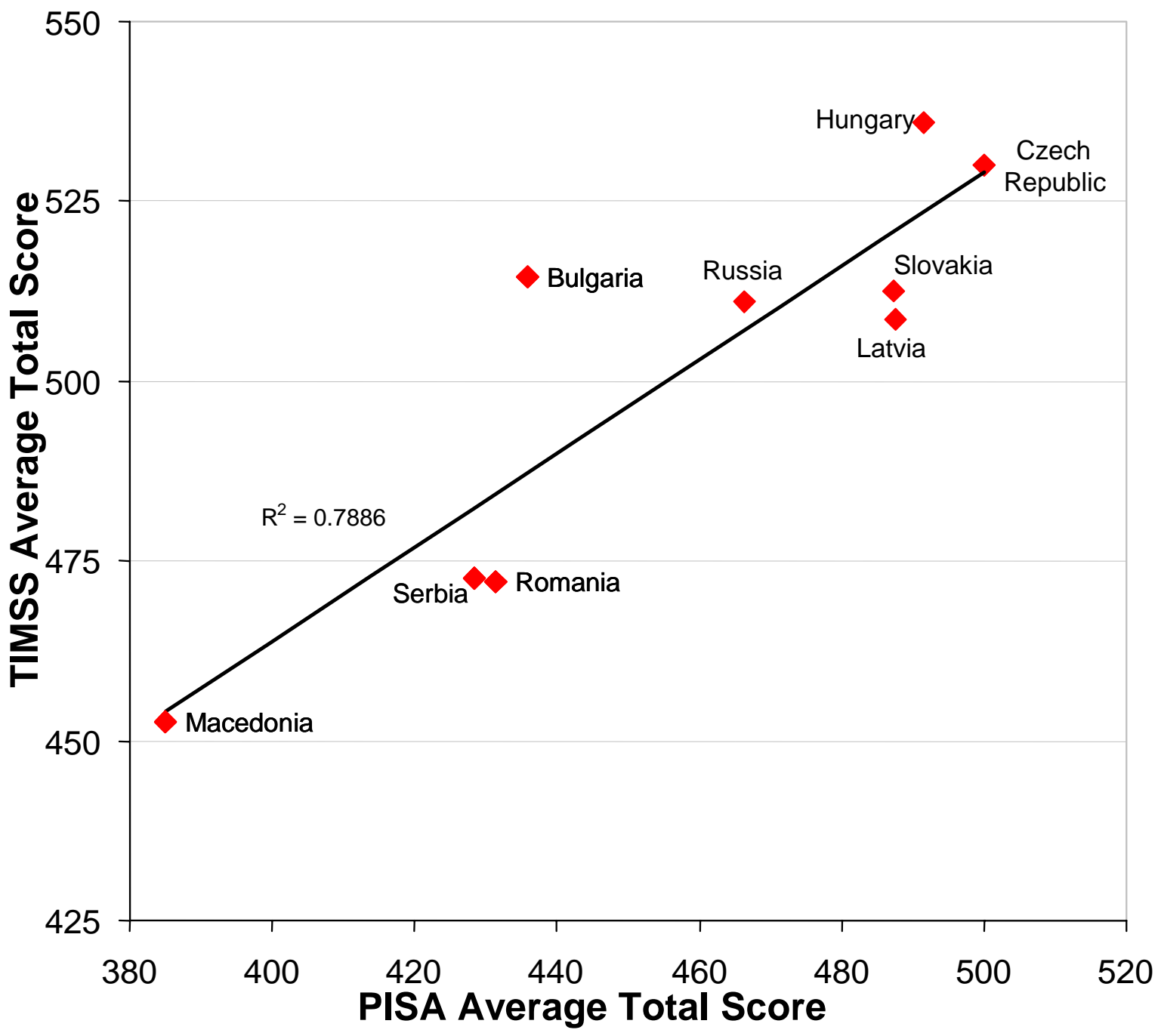

Average total score is the average of the 3 domains tested by PISA and the 2 tested by TIMSS. Bulgaria, Czech Republic, Macedonia, and Romania use TIMSS 1999 and PISA 2000 results; Hungary, Latvia, Russia, Serbia, and Slovakia use TIMSS 2003 and PISA 2003.

IEA, TIMSS 2003 International Mathematics Report (2004). IEA, TIMSS 2003 International Science Report (2004). OECD, Literacy Skills for the World of Tomorrow: Further Results from PISA 2000 (2003). OECD, First Results from PISA 2003 (2004). 
Figure 20

PISA vs. TIMSS

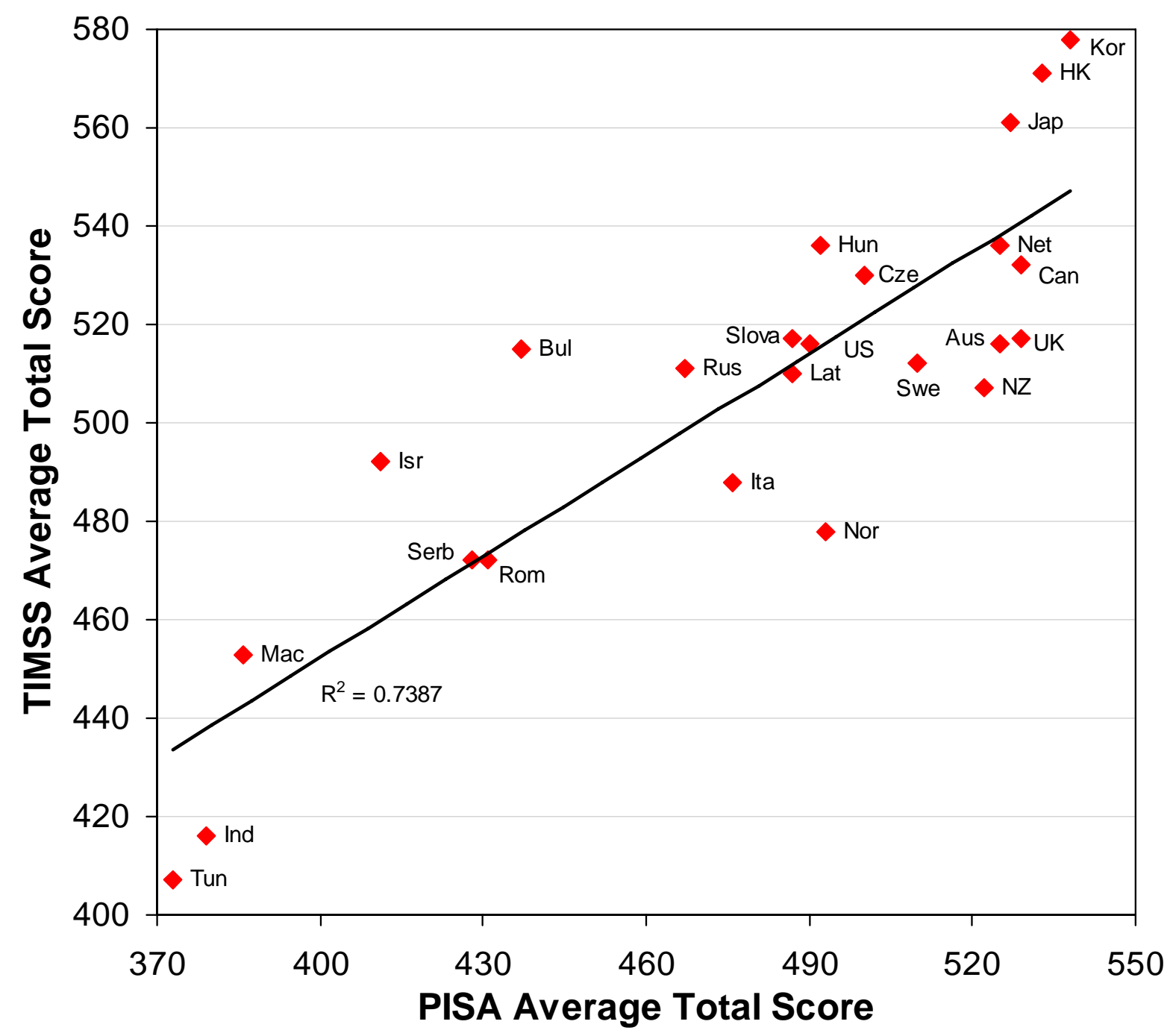

IEA, TIMSS 2003 International Mathematics Report (2004). IEA, TIMSS 2003 International Science Report (2004). OECD, Literacy Skills for the World of Tomorrow: Further Results from PISA 2000 (2003). OECD, First Results from PISA 2003 (2004). 


\section{Figure 21}

\section{Total Secondary Enrollment}

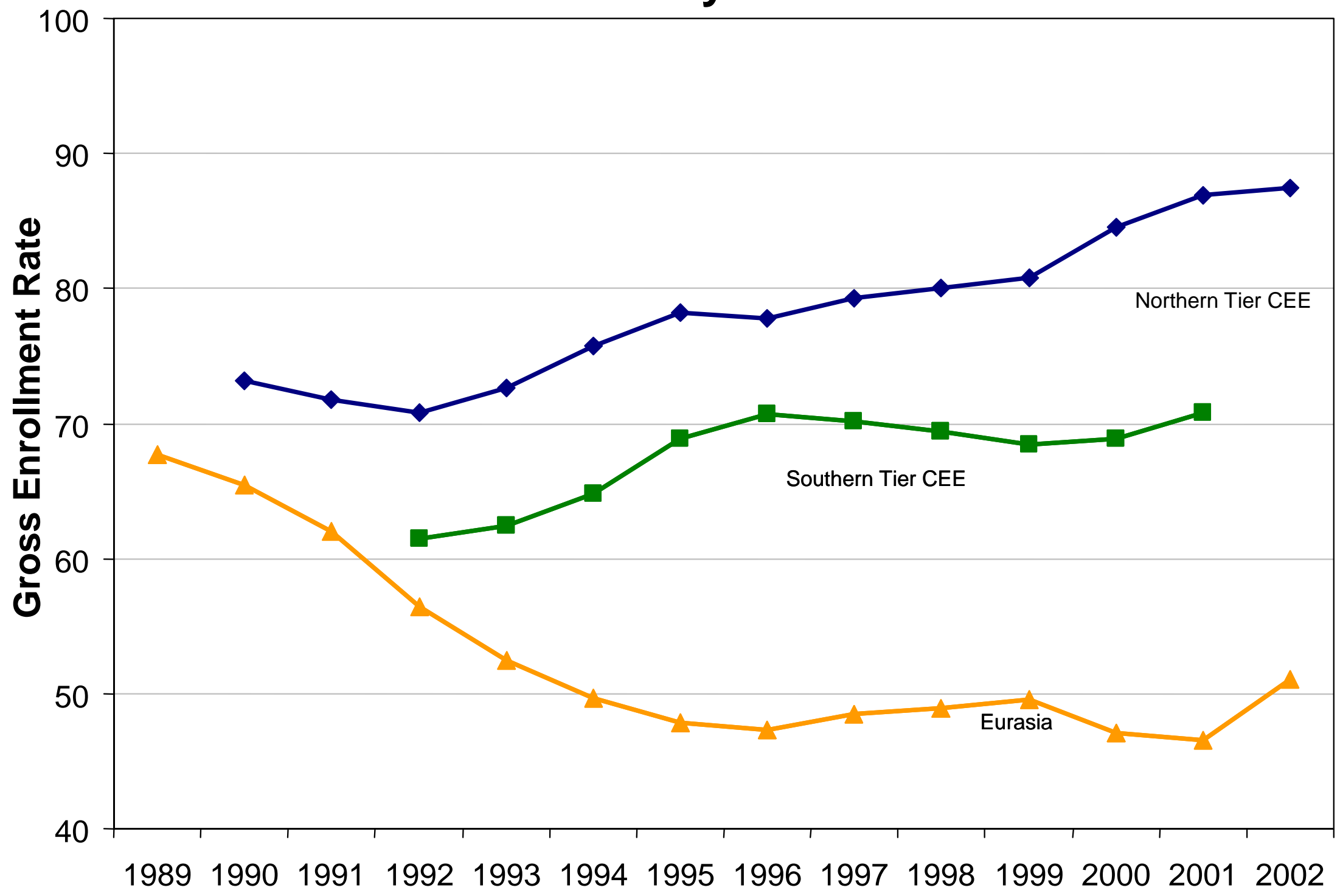

Northern Tier CEE excludes Slovenia because of incomplete data; Southern Tier CEE excludes Bosnia-Herzegovina and Serbia \& Montenegro. For 1989-1995: \% 14-17 year old population enrolled; For 1996-2002: \% 15-18 year old population enrolled. UNICEF, Social Monitor (2004). 
Figure 22

Higher Education Enrollment

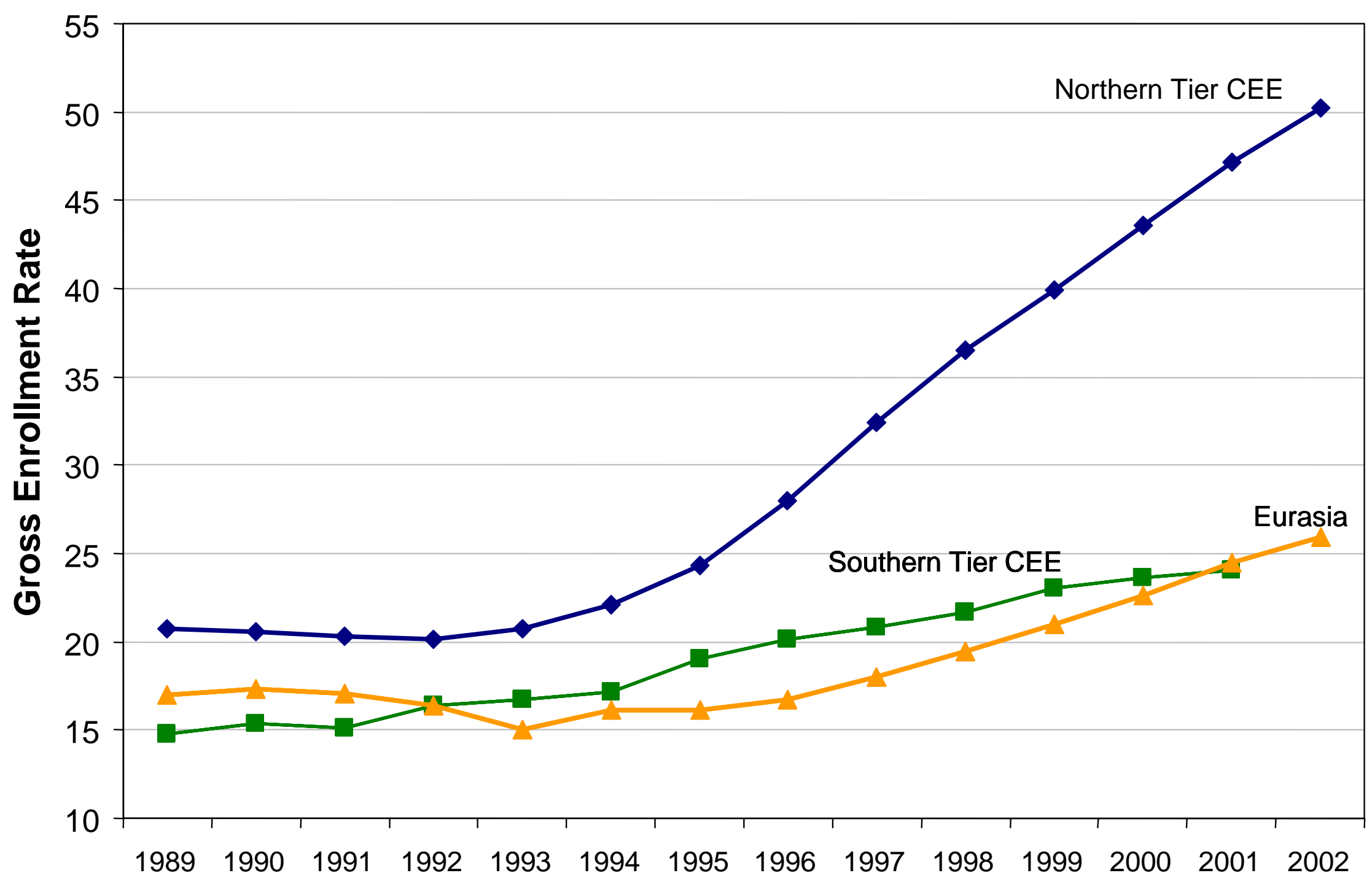

Bosnia-Herzegovina enrollment rates between 1993 and 1996 interpolated from 1993 and 1997 data.. For 1989-1995: \% 18-22 year old population enrolled; For 1996-2002: \% 19-23 year old population enrolled. UNICEF, Social Monitor (2004). 
Figure 23

Primary Enrollment

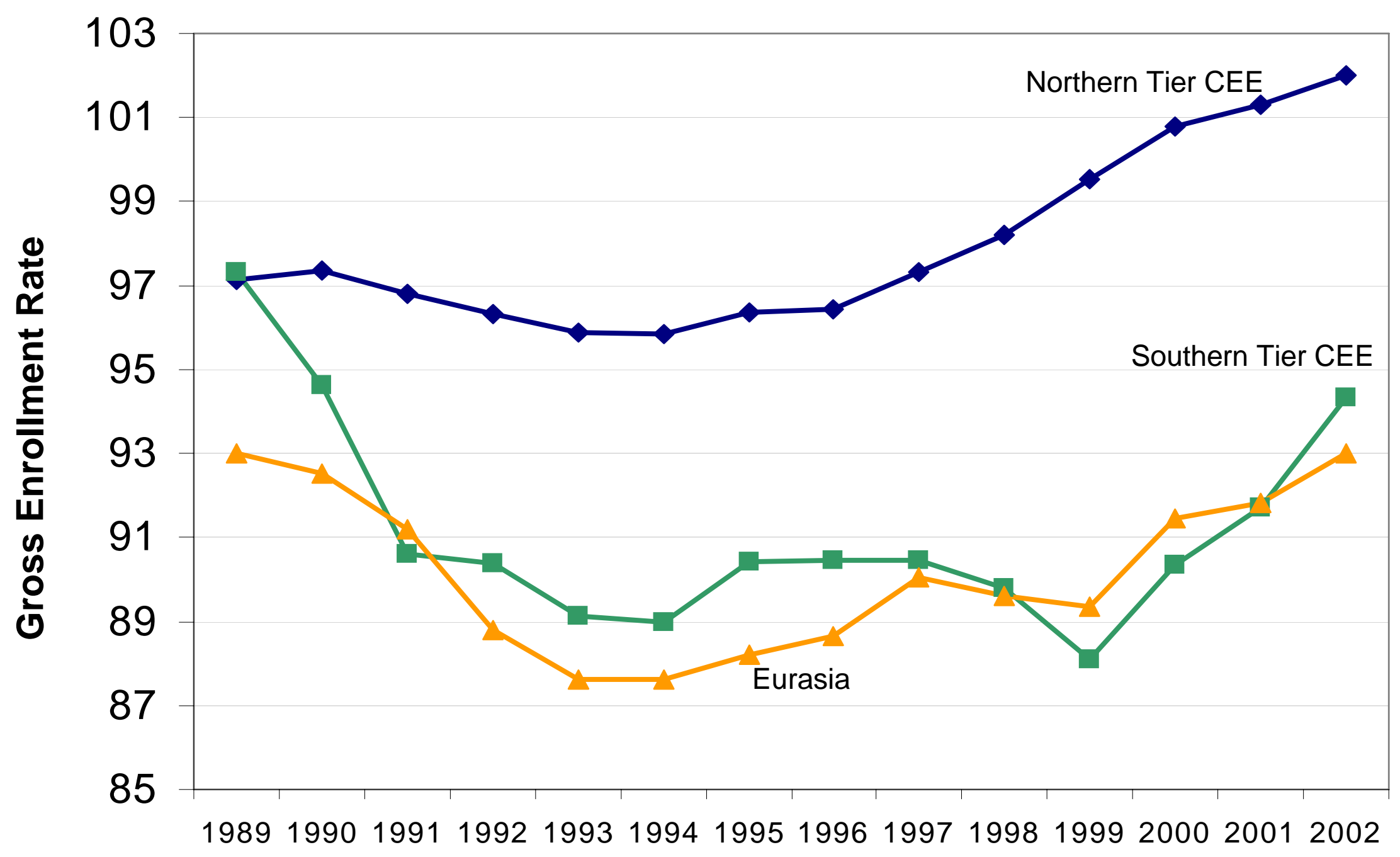


Figure 24

Pre-Primary Enrollment

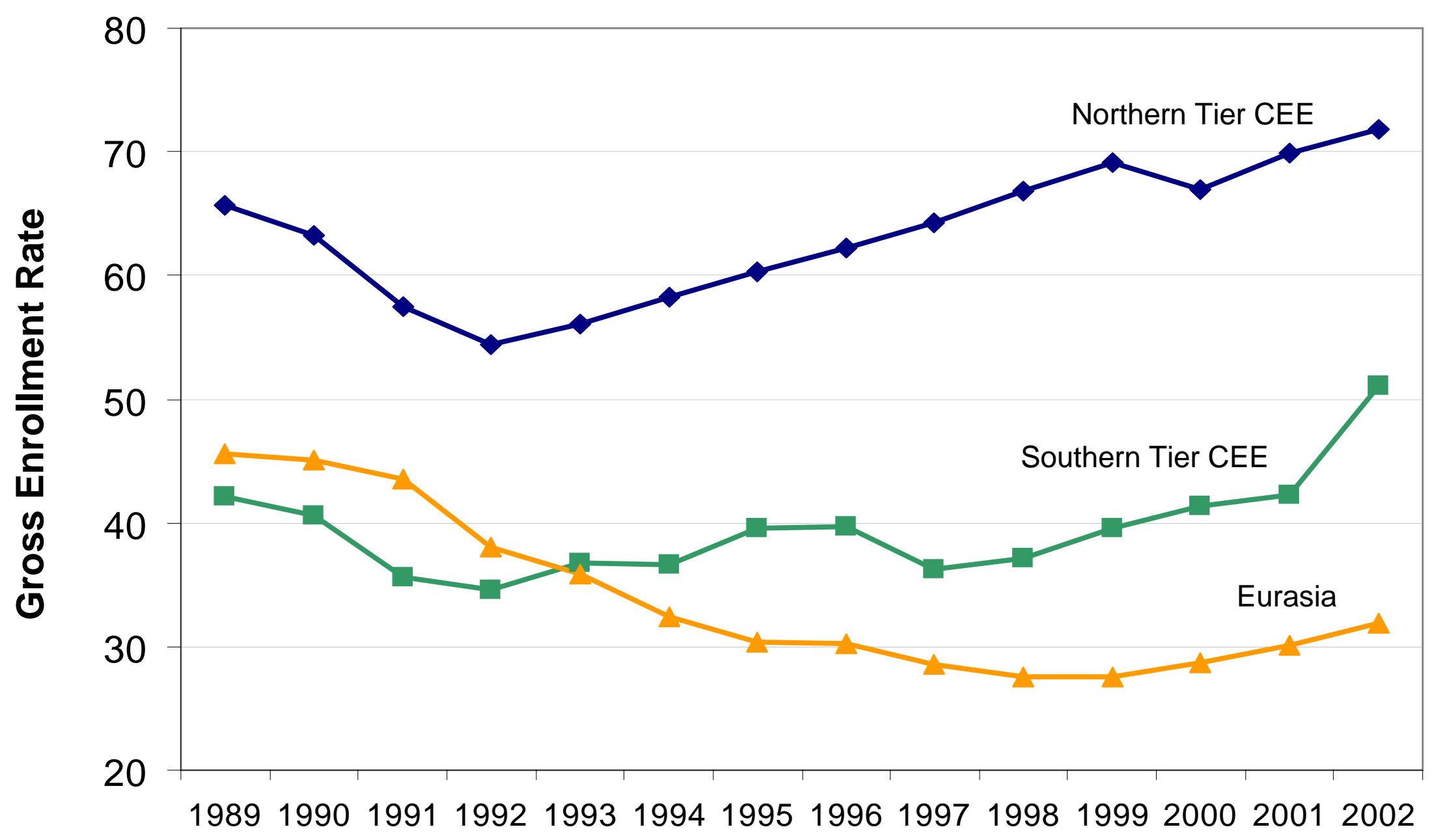

UNICEF, Social Monitor (2004). 


\section{Figure 25 \\ General Secondary Enrollment}

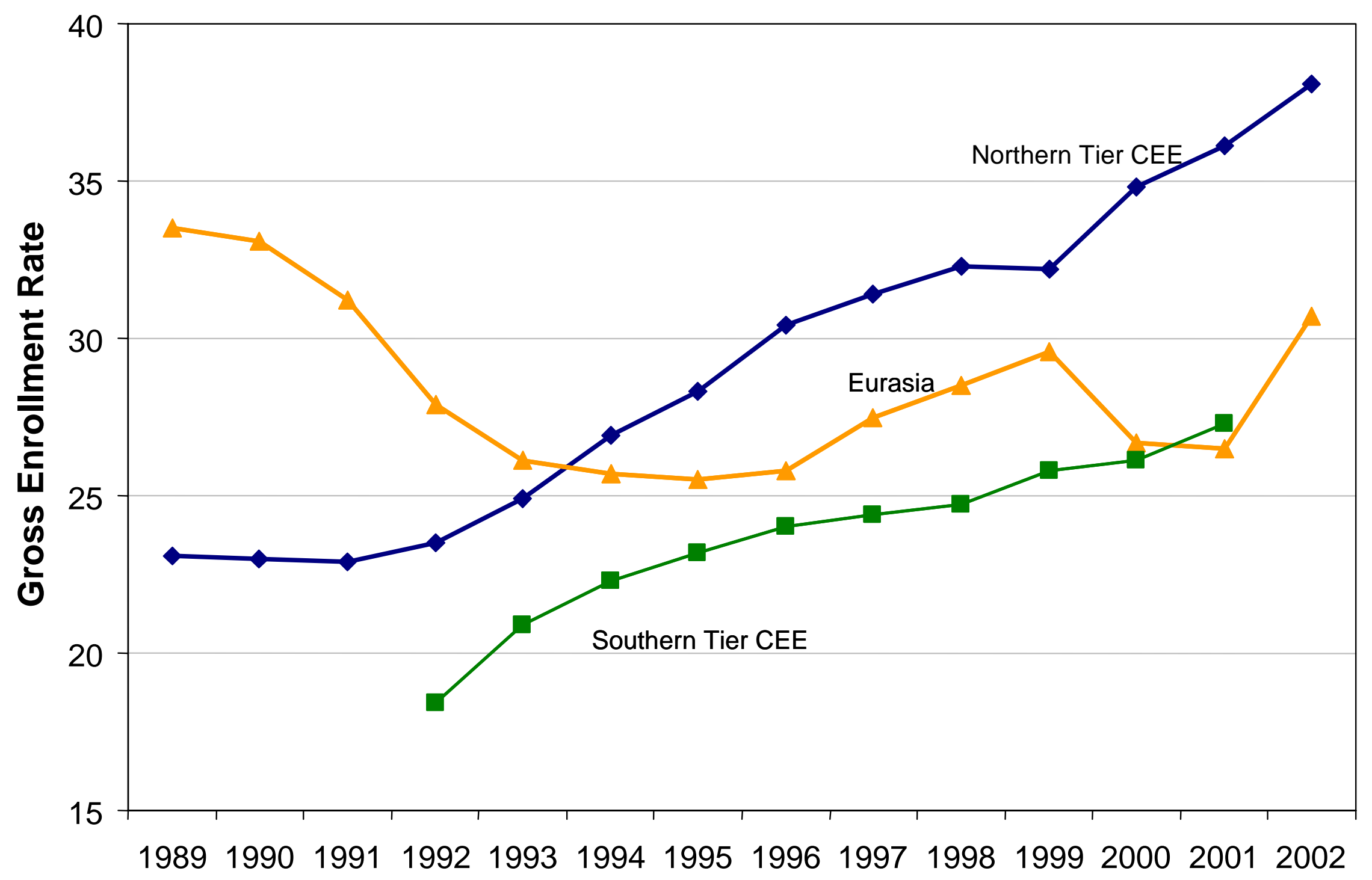

Northern Tier CEE excludes Slovenia because of incomplete data; Southern Tier CEE excludes Bosnia-Herzegovina. For 1989-1995: \% 14-17 year old population enrolled; For 1996-2002: \% 15-18 year old population enrolled. UNICEF, Social Monitor (2004). 
Figure $26 \quad$ Vocational/Technical Enrollment

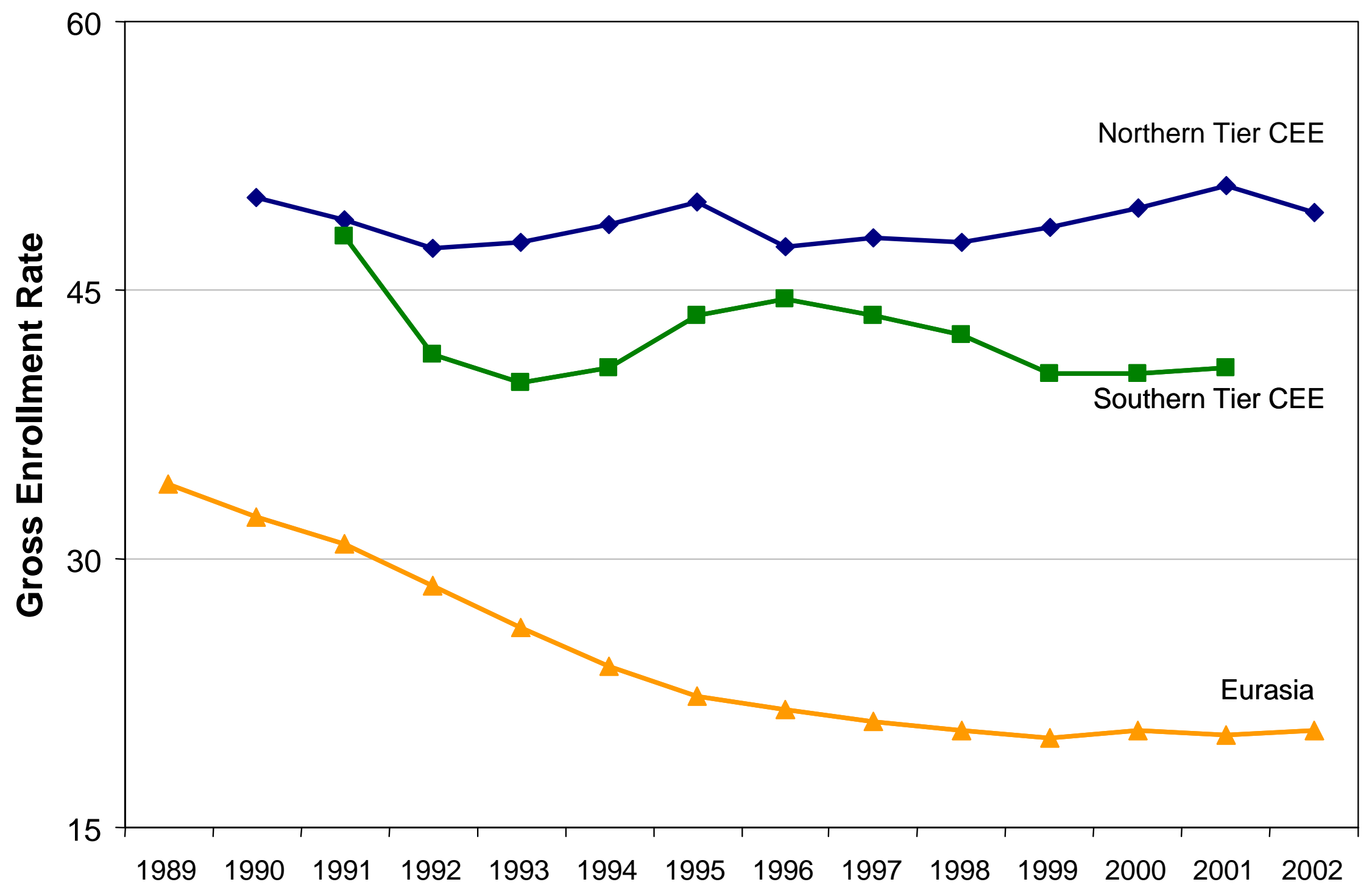

Northern Tier CEE excludes Slovenia because of incomplete data; Southern Tier CEE excludes Bosnia-Herzegovina and Serbia \& Montenegro. For 1989-1995: \% 14-17 year old population enrolled; For 1996-2002: \% 15-18 year old population enrolled. UNICEF, Social Monitor (2004). 


\begin{tabular}{|c|c|c|c|c|c|c|c|c|c|c|c|c|c|c|}
\hline \multicolumn{15}{|c|}{ Table 12. Total Secondary Enrollments } \\
\hline & 1989 & 1990 & 1991 & 1992 & 1993 & 1994 & 1995 & 1996 & 1997 & 1998 & 1999 & 2000 & 2001 & 2002 \\
\hline Poland & 90.2 & 89.3 & 89.3 & 90.5 & 92.5 & 94.9 & 96.5 & 97.4 & 98.3 & 99.5 & 101.2 & 102.9 & 108.8 & 111.8 \\
\hline Hungary & 72.7 & 73.5 & 74 & 76.6 & 79.5 & 82.4 & 86 & 89.9 & 93 & 95.1 & 96.3 & 103.5 & 105.7 & 107.6 \\
\hline Slovenia & - & - & - & - & 80.5 & 82.3 & 84.2 & 87.2 & 89.1 & 93.3 & 95.6 & 97.5 & 99 & 100.5 \\
\hline Czech Republic & 79.2 & 78.7 & 74 & 74.7 & 78 & 85 & 91 & 72 & 72.5 & 71 & 75.9 & 86.2 & 87.9 & 90.6 \\
\hline Bulgaria & 78.2 & 77 & 74.2 & 73 & 72.2 & 74.8 & 76.1 & 75.4 & 73.6 & 73.8 & 74.1 & 75.4 & 79 & 85.5 \\
\hline Slovakia & 79 & 78.2 & 78 & 79.8 & 81.9 & 84.9 & 88.1 & 89.7 & 90.4 & 91.5 & 80 & 82.7 & 88.5 & 83.8 \\
\hline Croatia & - & - & 59.7 & 66.3 & 76.4 & 86.7 & 103.2 & 109.2 & 104.9 & 98.3 & 89.8 & 85.5 & 83.5 & 83.1 \\
\hline Estonia & - & 57.2 & 58.2 & 58.5 & 61.4 & 66.6 & 67.6 & 70.3 & 70.7 & 68.8 & 74.6 & 78.6 & 80.9 & 79.7 \\
\hline Romania & - & 89.9 & 73.8 & 65 & 64.2 & 66.6 & 69.2 & 70.1 & 70.3 & 69.6 & 70.2 & 72.2 & 73.2 & 73.6 \\
\hline Latvia & 70.2 & 66.4 & 65.2 & 61.8 & 62.5 & 61.8 & 61.4 & 64.4 & 67.8 & 69.3 & 74.4 & 74.7 & 72.3 & 71.8 \\
\hline Belarus & 77.2 & 75.6 & 74.2 & 72.2 & 70.2 & 69.4 & 67 & 67.6 & 70 & 69.9 & 71.5 & 71.2 & 70.1 & 71.6 \\
\hline Russia & 77.8 & 74.9 & 72.2 & 68.4 & 66 & 64.6 & 65.9 & 67.1 & 68.1 & 68.6 & 69.7 & 70.3 & 69.9 & 71.5 \\
\hline FYR Macedonia & - & - & - & 54.4 & 54.1 & 55.3 & 57 & 58.7 & 60.2 & 62.6 & 65.5 & 67.4 & 69.1 & 69.6 \\
\hline Serbia and Montenegro & - & - & - & - & - & - & - & - & - & - & 57.5 & 56 & 55 & - \\
\hline Uzbekistan & 69.4 & 67.1 & 63.9 & 57.6 & 52.9 & 50.7 & 48.6 & 47.7 & 50.6 & 53.5 & 55.9 & 55.2 & 53.1 & 68.4 \\
\hline Lithuania & 73.3 & 68.9 & 63.9 & 53.5 & 52.3 & 54 & 56.8 & 61.1 & 62.5 & 64.7 & 63.1 & 62.8 & 64.3 & 66.7 \\
\hline Kazakhstan & 76.1 & 74.2 & 70.3 & 66.2 & 62.3 & 58.5 & 57.1 & 57.3 & 57.4 & 59.8 & 59.6 & 52.1 & 54.5 & 62 \\
\hline Ukraine & 65.6 & 64.6 & 63.9 & 62.3 & 59.3 & 58.2 & 57.4 & 58.2 & 57.6 & 58 & 59.3 & 59.3 & 58.8 & 60.8 \\
\hline Bosnia-Herzegovina & - & - & - & - & - & - & - & - & - & - & - & 51.9 & 51.5 & 51.7 \\
\hline Albania & 79.2 & 76.1 & 58.6 & 48.9 & 44.9 & 40.8 & 39 & 39.9 & 41.8 & 42.7 & 42.4 & 43.8 & 49 & \\
\hline Armenia & 67.5 & 63.4 & 58.3 & 54.1 & 49.5 & 45.6 & 40.4 & 41.3 & 41.5 & 43.2 & 44.5 & 42.4 & 41.1 & 49.1 \\
\hline Kyrgyzstan & 65 & 63.5 & 61.5 & 57.1 & 49.3 & 45.7 & 41.3 & 41.3 & 44.2 & 48.3 & 50.1 & 36 & 36.4 & 47.5 \\
\hline Georgia & 56.6 & 55.5 & 48.6 & 41.4 & 38 & 37.4 & 39.7 & 42.2 & 42.1 & 45.1 & 44.6 & 46.2 & 45.8 & 45.2 \\
\hline Azerbaijan & 62.8 & 59.5 & 58.7 & 52 & 43.5 & 38.5 & 35.3 & 36.9 & 40.6 & 41 & 41.2 & 32.9 & 32.6 & 42.5 \\
\hline Moldova & 67.1 & 64.3 & 57.3 & 43.5 & 41.6 & 40.6 & 40.3 & 41.7 & 47.1 & 45.7 & 38.5 & 37.5 & 37.9 & 40.1 \\
\hline Turkmenistan & 66.8 & 63.1 & 59.7 & 56.6 & 53.3 & 47.7 & 44.1 & 34.1 & 30.9 & 29.5 & 33.9 & 31 & 30.6 & 27.4 \\
\hline Tajikistan & 60.1 & 59.4 & 55.6 & 45.5 & 42.4 & 39.5 & 36.1 & 32.6 & 31.3 & 24.7 & 26.4 & 31.4 & 29.1 & 26.9 \\
\hline Northern Tier CEE & - & 73.2 & 71.8 & 70.8 & 72.6 & 75.7 & 78.2 & 77.8 & 79.3 & 80 & 80.8 & 84.5 & 86.9 & 87.4 \\
\hline Southern Tier CEE & - & - & - & 61.5 & 62.4 & 64.8 & 68.9 & 70.7 & 70.2 & 69.4 & 68.4 & 68.9 & 70.8 & - \\
\hline Eurasia (includes CARs) & 67.7 & 65.4 & 62 & 56.4 & 52.4 & 49.7 & 47.8 & 47.3 & 48.5 & 48.9 & 49.6 & 47.1 & 46.6 & 51.1 \\
\hline Central Asian Republics & 67.5 & 65.5 & 62.2 & 56.6 & 52 & 48.4 & 45.4 & 42.6 & 42.9 & 43.1 & 45.2 & 41.1 & 40.7 & 46.5 \\
\hline
\end{tabular}

Gross enrollment rates; general secondary plus vocational/technical enrollments. For 1989-1995: \%14-17 year old population enrolled; for 1996-2002:

\% 15-18 year old population enrolled. UNICEF, Social Monitor (2004). 


\begin{tabular}{|c|c|c|c|c|c|c|c|c|c|c|c|c|c|c|}
\hline & 1989 & 1990 & 1991 & 1992 & 1993 & 1994 & 1995 & 1996 & 1997 & 1998 & 1999 & 2000 & 2001 & 2002 \\
\hline Lithuania & 35.5 & 34.9 & 33 & 31.8 & 31.1 & 33.6 & 35.9 & 40.1 & 41.1 & 43.2 & 37.6 & 42.2 & 45.9 & 48.9 \\
\hline Estonia & 37.8 & 36.7 & 37.2 & 38 & 41 & 45.9 & 46.3 & 47.6 & 47.7 & 45.2 & 44.8 & 45 & 46.4 & 46.8 \\
\hline Poland & 20.3 & 20.9 & 22.5 & 24.3 & 25.9 & 27.7 & 29.5 & 30.3 & 31.8 & 33.7 & 36.2 & 38.9 & 42.4 & 46.0 \\
\hline Latvia & 22.1 & 20.9 & 20.6 & 20.8 & 25.2 & 27.3 & 29 & 37.1 & 39.1 & 41.2 & 43.1 & 43.1 & 41 & 41.6 \\
\hline Albania & 24.6 & 22.4 & 29 & 30.8 & 31.8 & 31.8 & 30.9 & 32.8 & 35.2 & 36.4 & 36.4 & 37.2 & 41.3 & - \\
\hline Bulgaria & 30.9 & 29.8 & 28.9 & 29.6 & 30 & 31.6 & 32.5 & 32.2 & 31.4 & 32 & 32.6 & 33.1 & 35 & 38.3 \\
\hline Kazakhstan & 32.5 & 33.3 & 32 & 29.5 & 28 & 26.6 & 26.2 & 30.1 & 34.5 & 38.5 & 39.3 & 30.6 & 31.2 & 37.9 \\
\hline Slovenia & - & - & - & - & 19.5 & 20.1 & 20.5 & 21.6 & 22.7 & 25.6 & 29 & 31.9 & 35.1 & 37.5 \\
\hline Armenia & 35.9 & 34.3 & 32.5 & 31.3 & 31.2 & 30.7 & 29.1 & 29.6 & 30.6 & 31.8 & 32.8 & 32.1 & 30.5 & 37.5 \\
\hline Hungary & 17.3 & 17.6 & 18.2 & 19.6 & 20.8 & 22.1 & 23.2 & 24.4 & 25.7 & 26.8 & 27.8 & 34.3 & 35.4 & 36.5 \\
\hline Kyrgyzstan & 36.7 & 36.6 & 35.5 & 31.9 & 27.1 & 26.1 & 25.2 & 27.3 & 30.9 & 35.2 & 37.5 & 23.5 & 24.5 & 36.1 \\
\hline Uzbekistan & 36.3 & 37.1 & 36 & 30.8 & 27.6 & 27.2 & 26.3 & 26.2 & 28 & 29.6 & 30.9 & 22.7 & 21.2 & 34.9 \\
\hline Azerbaijan & 34 & 33.5 & 33.7 & 31.7 & 27.8 & 25.7 & 24.6 & 26.7 & 30.9 & 31.5 & 31.6 & 23.2 & 22.5 & 32.5 \\
\hline Georgia & 39.9 & 39.2 & 33.7 & 26 & 24.1 & 23.1 & 25.7 & 26.4 & 25.3 & 26.1 & 26.5 & 30.3 & 31.4 & 32.0 \\
\hline Ukraine & 25.3 & 25 & 24.4 & 23.3 & 22.8 & 23.6 & 24.1 & 25.5 & 27.4 & 29.3 & 31.1 & 30.9 & 30.5 & 31.4 \\
\hline Russia & 24.4 & 24.7 & 23.6 & 22.6 & 22.3 & 23.4 & 24.5 & 25.7 & 27.1 & 28.5 & 29.1 & 28.6 & 28.7 & 29.5 \\
\hline Slovakia & 14.3 & 15 & 15.7 & 16.7 & 17.8 & 19 & 20.5 & 21.6 & 22.3 & 22.6 & 21.7 & 23.1 & 24.9 & 27.8 \\
\hline Belarus & 27.1 & 26.8 & 26.2 & 25.2 & 24.1 & 25 & 24.8 & 26.6 & 28.2 & 27.9 & 28.9 & 27.9 & 26.8 & 27.7 \\
\hline Moldova & 27.4 & 26.3 & 22.2 & 17.1 & 17.2 & 17.6 & 18 & 19.2 & 21.7 & 22.9 & 21.1 & 22.7 & 24.3 & 27.2 \\
\hline FYR Macedonia & - & - & - & 10.6 & 14.6 & 15.9 & 17.3 & 18 & 18.8 & 20.3 & 22.2 & 24.1 & 25.7 & 27.0 \\
\hline Romania & - & 11.5 & 15.9 & 17.2 & 18.6 & 19.6 & 20.1 & 21 & 21.4 & 21.4 & 26.3 & 26.1 & 26.3 & 26.2 \\
\hline Turkmenistan & 41.7 & 40.4 & 37.5 & 35.4 & 34.6 & 34.5 & 33.5 & 23.7 & 23.8 & 24.7 & 28.7 & 25.1 & 25.1 & 21.9 \\
\hline Croatia & - & - & 7.8 & 12.5 & 18 & 21.9 & 25.5 & 26.9 & 25.9 & 24.4 & 22.9 & 22.1 & 21.8 & 21.6 \\
\hline Tajikistan & 40.4 & 40.3 & 37.2 & 29.5 & 26.9 & 25.5 & 23.8 & 22 & 22.2 & 16.3 & 17.8 & 22.8 & 21.1 & 19.1 \\
\hline Czech Republic & 14.1 & 14.9 & 13.1 & 13 & 12.3 & 12.7 & 13.6 & 11.9 & 12.4 & 13.4 & 14.5 & 17.3 & 16.9 & 18.9 \\
\hline Bosnia-Herzegovina & - & - & - & - & - & - & - & - & - & - & - & 16.1 & 16 & 16.6 \\
\hline Serbia and Montenegro & - & - & 6.2 & 9.5 & 12.4 & 12.8 & 12.9 & 13.5 & 13.7 & 14 & 14.2 & 13.9 & 13.8 & - \\
\hline Northern Tier CEE & 23.1 & 23 & 22.9 & 23.5 & 24.9 & 26.9 & 28.3 & 30.4 & 31.4 & 32.3 & 32.2 & 34.8 & 36.1 & 38.1 \\
\hline Southern Tier CEE & - & - & - & 20.1 & 22.6 & 24.2 & 25.3 & 26.2 & 26.5 & 26.9 & 28.1 & 28.5 & 30 & - \\
\hline Eurasia (includes CARs) & 33.5 & 33.1 & 31.2 & 27.9 & 26.1 & 25.7 & 25.5 & 25.8 & 27.5 & 28.5 & 29.6 & 26.7 & 26.5 & 30.7 \\
\hline Central Asian Republics & 37.5 & 37.5 & 35.6 & 31.4 & 28.8 & 28 & 27 & 25.9 & 27.9 & 28.9 & 30.8 & 24.9 & 24.6 & 30.0 \\
\hline
\end{tabular}

UNICEF, Social Monitor (2004). Gross enrollment rates. For 1989-1995: \%14-17 year old population enrolled; for 1996-2002: \% 15-18 year old population enrolled. 


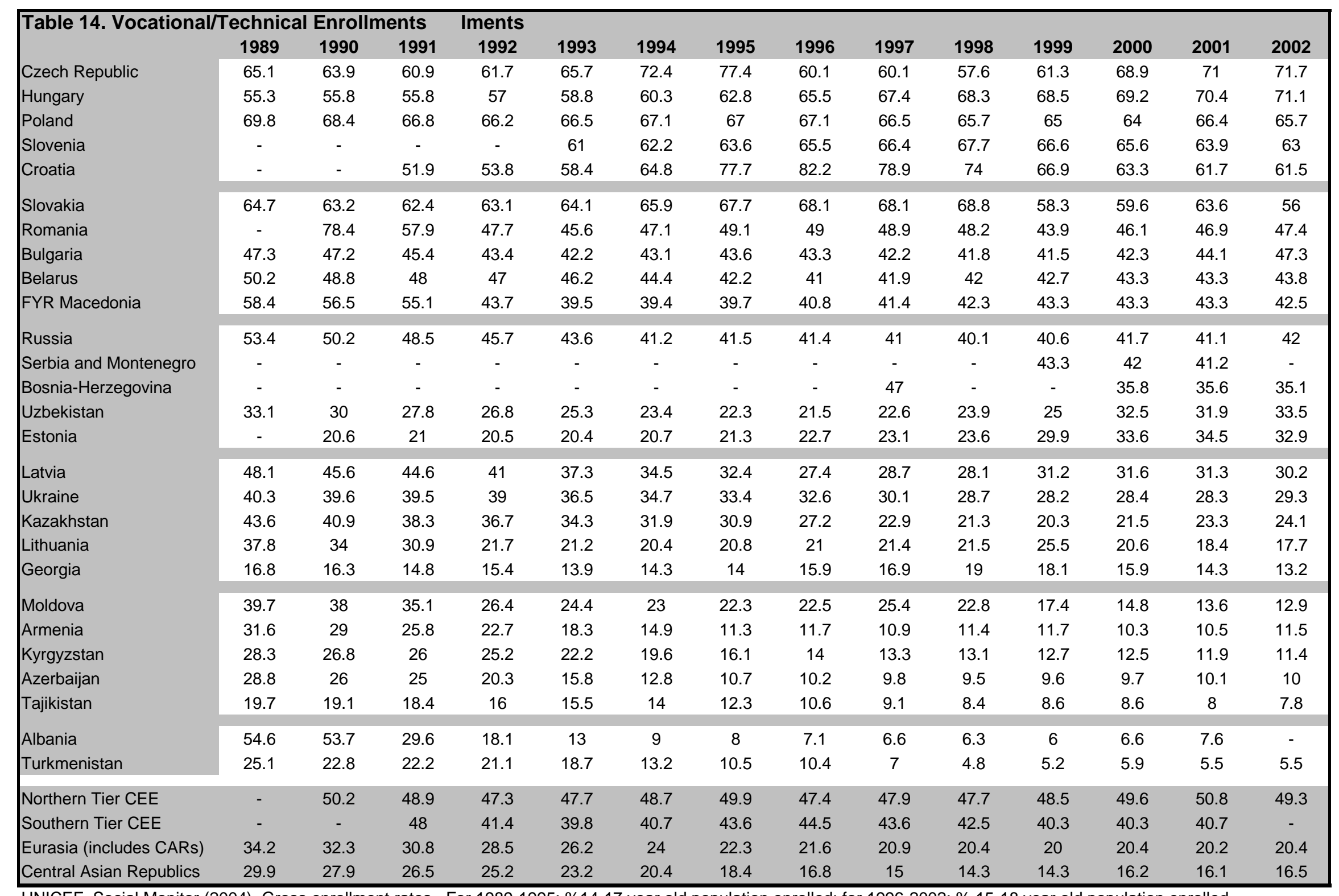

UNICEF, Social Monitor (2004). Gross enrollment rates. For 1989-1995: \%14-17 year old population enrolled; for 1996-2002: \% 15-18 year old population enrolled. 
Figure 27

Total Secondary Enrollment: Southern Tier CEE

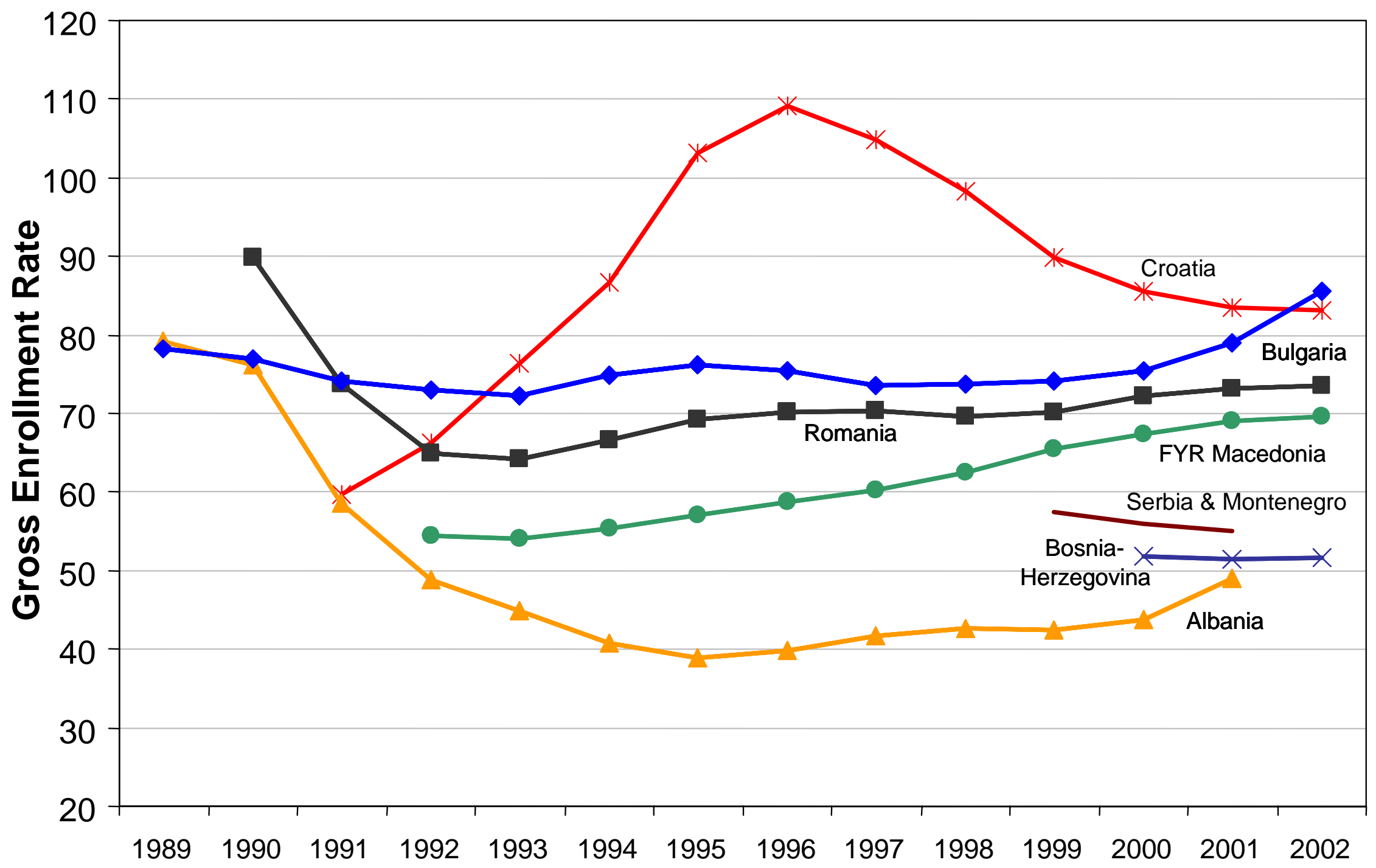

For 1989-1995: \% 14-17 year old population enrolled; For 1996-2002: \% 15-18 year old population enrolled. UNICEF, Social Monitor (2004). 
Figure 28

Total Secondary Enrollment:

Eurasia

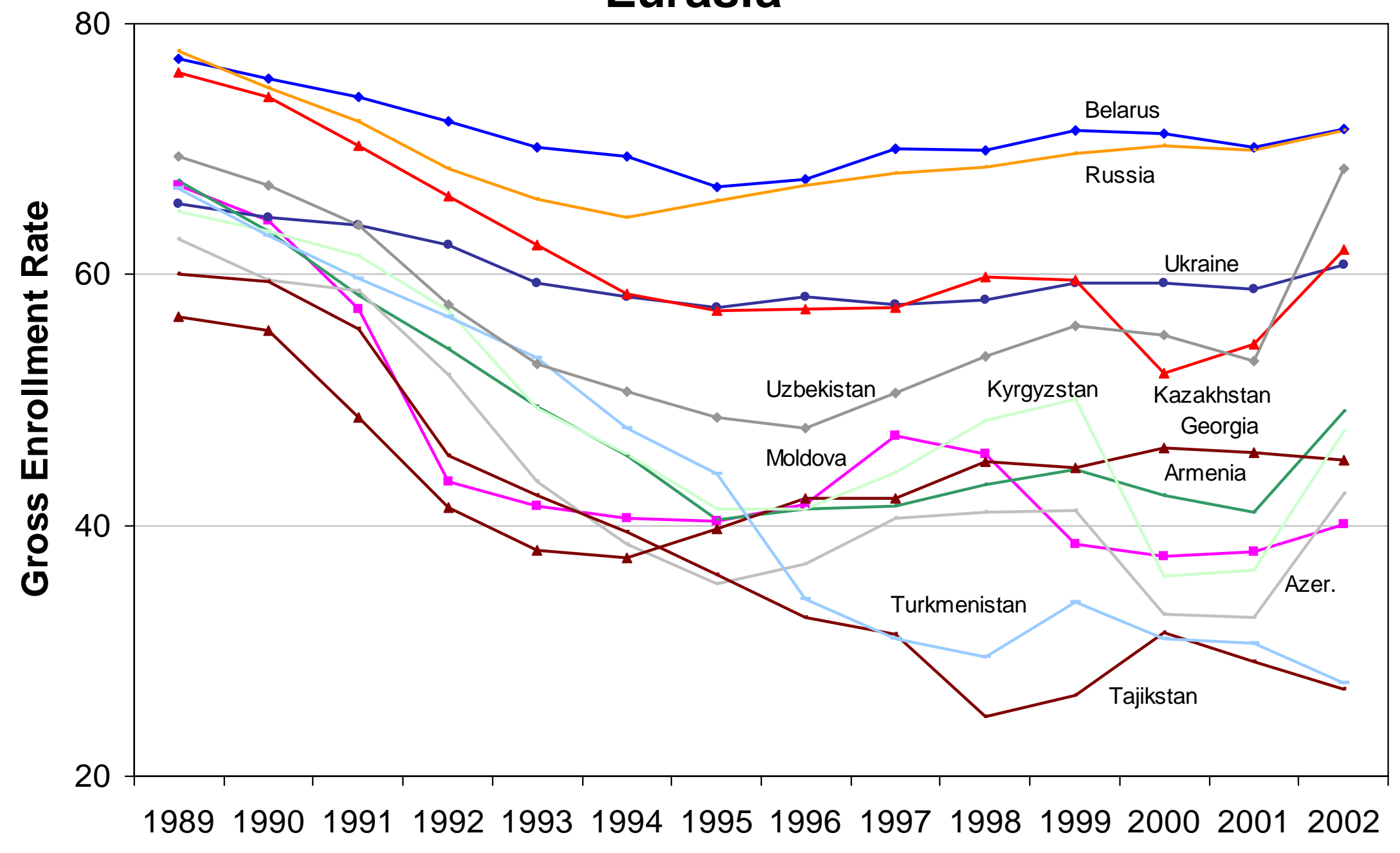

For 1989-1995: \% 14-17 year old population enrolled; For 1996-2002: \% 15-18 year old population enrolled. UNICEF, Social Monitor (2004). 
Figure 29

General Secondary Enrollment: Southern Tier CEE

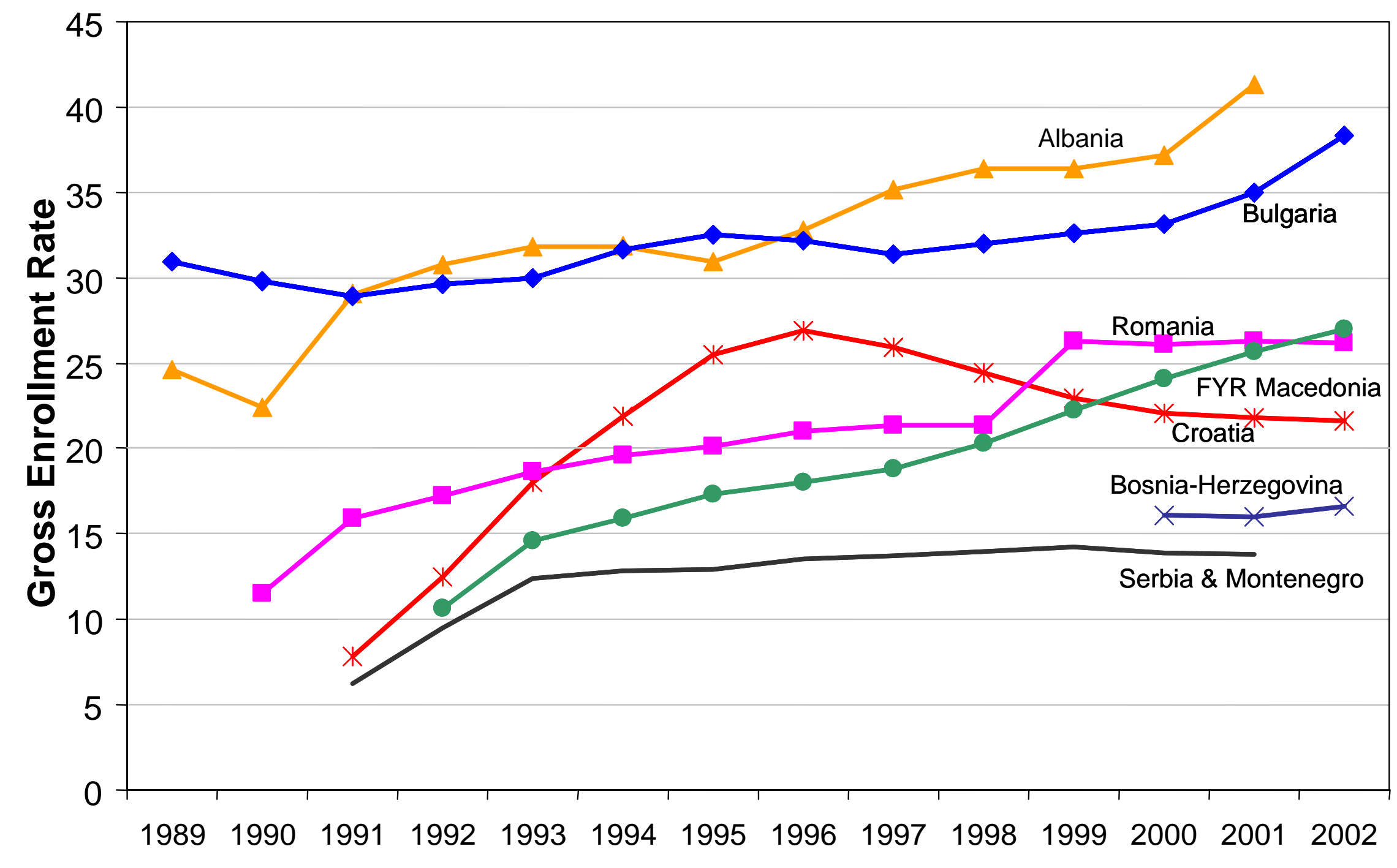

For 1989-1995: \% 14-17 year old population enrolled; For 1996-2002: \% 14-17 year old population enrolled. UNICEF, Social Monitor (2004). 
Figure 30

\section{General Secondary Enrollment:} Eurasia

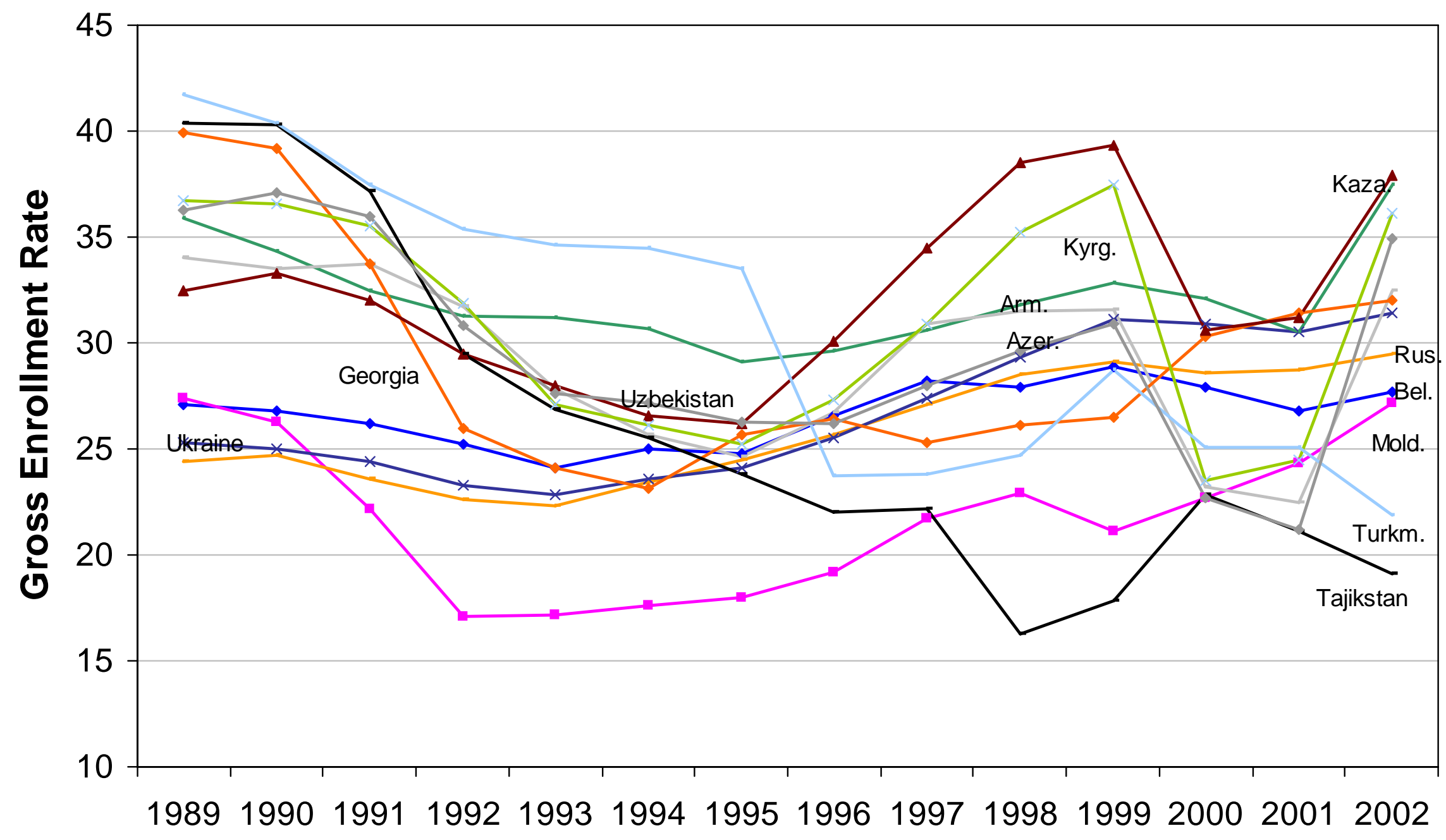

For 1989-1995: \% 14-17 year old population enrolled; For 1996-2002: \% 15-18 year old population enrolled. UNICEF, Social Monitor (2004). 
Figure 31

\section{Vocational/Technical Enrollment: Southern Tier CEE}

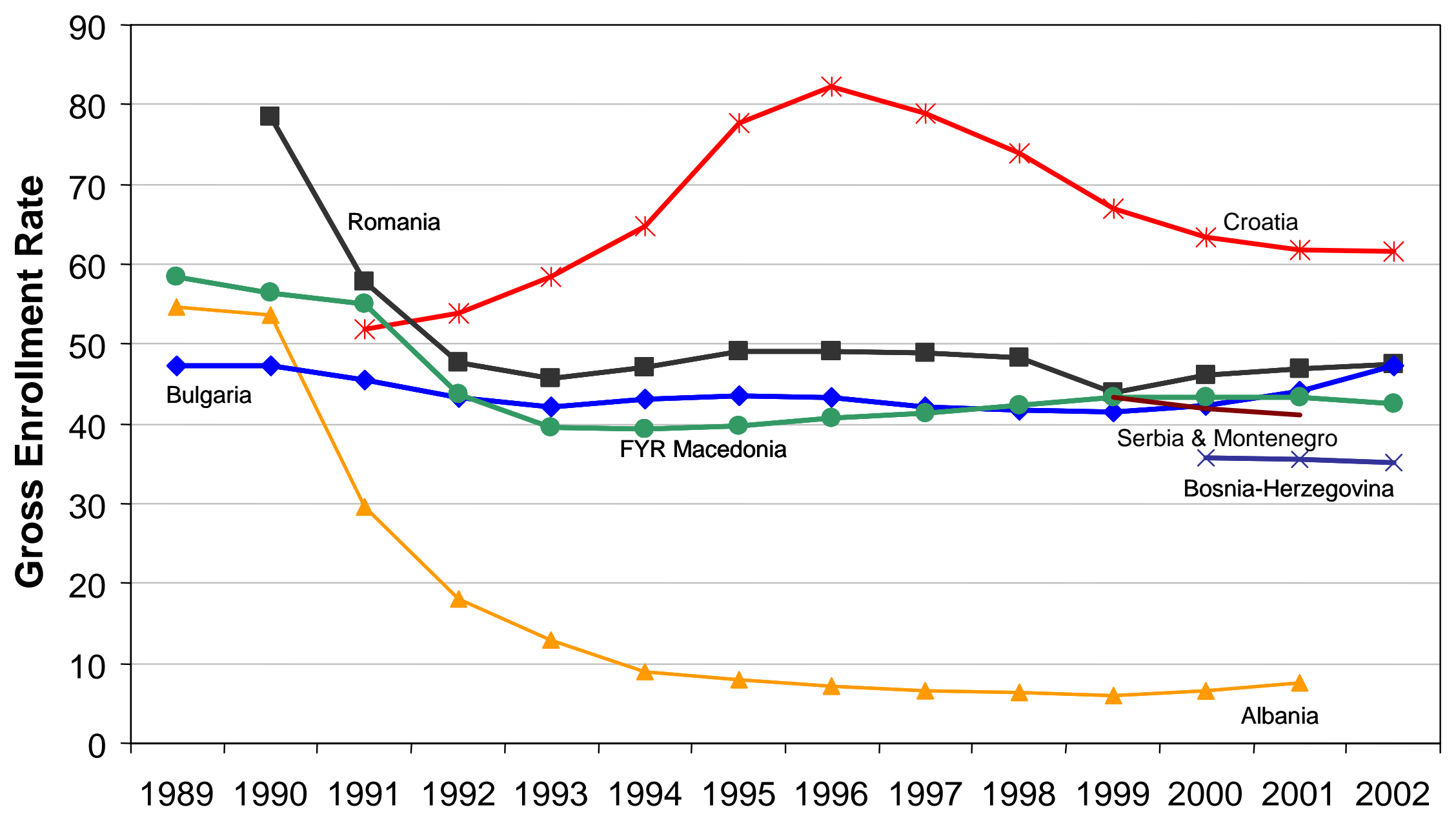

For 1989-1995: \% 14-17 year old population enrolled; For 1996-2002: \% 15-18 year old population enrolled. UNICEF, Social Monitor (2004). 
Figure 32

\section{Vocational/Technical Enrollment:}

Eurasia

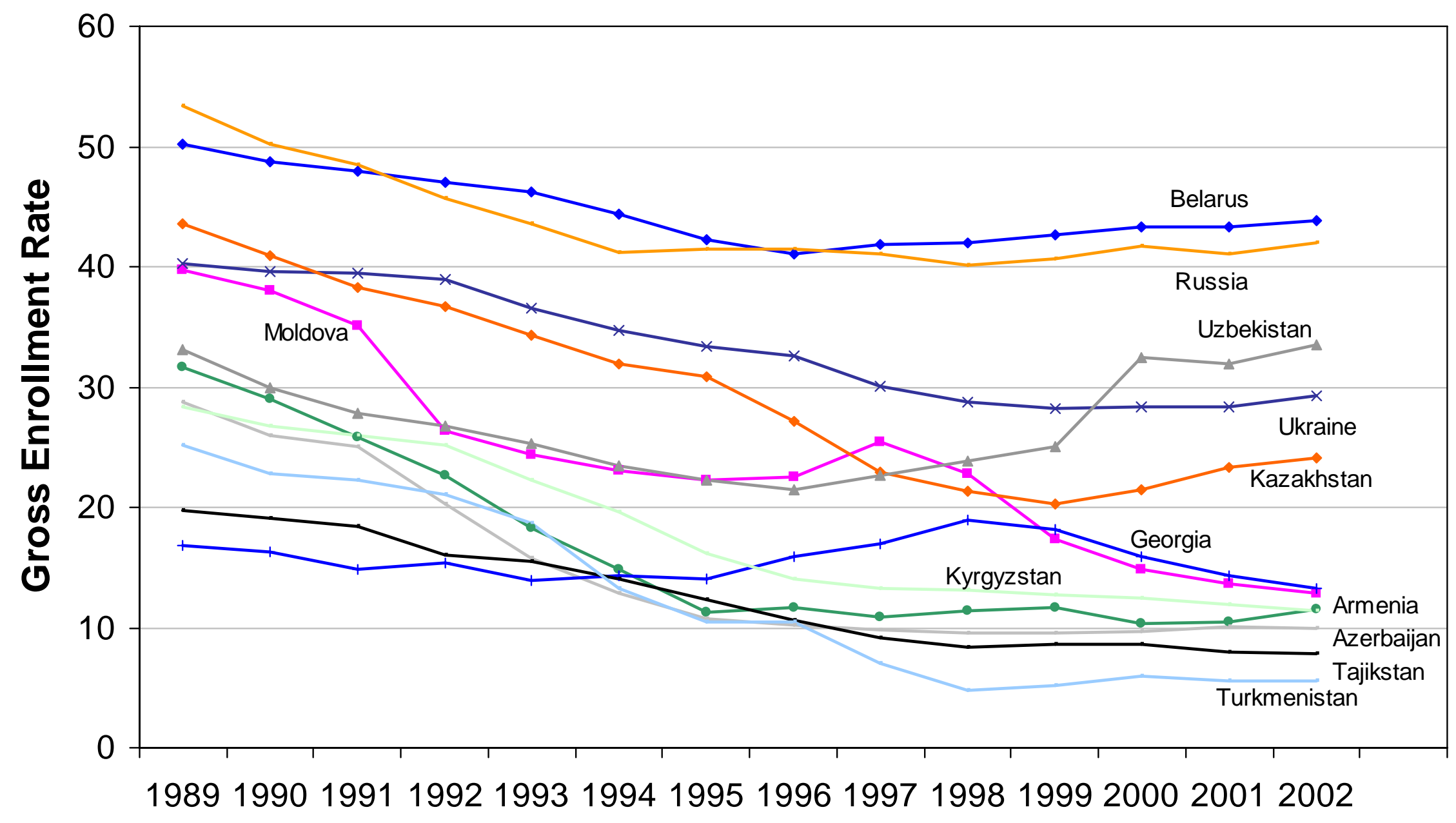

For 1989-1995: \% 14-17 year old population enrolled; For 1996-2002: \% 15-18 year old population enrolled. UNICEF, Social Monitor (2004). 
Table 15. Secondary Enrollments

\begin{tabular}{|c|c|c|c|c|c|c|c|}
\hline & $\begin{array}{c}1989 \\
\text { General }\end{array}$ & Vocational & Ratio & $\begin{array}{c}2002 \\
\text { General }\end{array}$ & Vocational & Ratio & $\begin{array}{c}\text { Ratio } \\
\text { Change }\end{array}$ \\
\hline Czech Republic & 14.1 & 65.1 & 4.6 & 18.9 & 71.7 & 3.8 & -0.8 \\
\hline Hungary & 17.3 & 55.3 & 3.2 & 36.5 & 71.1 & 1.9 & -1.2 \\
\hline Poland & 20.3 & 69.8 & 3.4 & 46 & 65.7 & 1.4 & -2.0 \\
\hline Slovakia & 14.3 & 64.7 & 4.5 & 27.8 & 56 & 2.0 & -2.5 \\
\hline Slovneia & 19.5 & 61 & 3.1 & 37.5 & 63 & 1.7 & -1.4 \\
\hline Estonia & 37.8 & 20.6 & 0.5 & 46.8 & 32.9 & 0.7 & 0.2 \\
\hline Lativa & 22.1 & 48.1 & 2.2 & 41.6 & 30.2 & 0.7 & -1.5 \\
\hline Lithuania & 35.5 & 37.8 & 1.1 & 48.9 & 17.7 & 0.4 & -0.7 \\
\hline Bulgari & 30.9 & 47.3 & 1.5 & 38.3 & 47.3 & 1.2 & -0.3 \\
\hline Romania & 11.5 & 78.4 & 6.8 & 26.2 & 47.4 & 1.8 & -5.0 \\
\hline Albania & 24.6 & 54.6 & 2.2 & 41.3 & 7.6 & 0.2 & -2.0 \\
\hline Bosnia & & & & 16.6 & 35.1 & 2.1 & \\
\hline Croatia & 7.8 & 51.9 & 6.7 & 21.6 & 61.5 & 2.8 & -3.8 \\
\hline Macedonia & 10.6 & 58.4 & 5.5 & 27 & 42.5 & 1.6 & -3.9 \\
\hline Serbia & 6.2 & & & 13.8 & 41.2 & 3.0 & \\
\hline Belarus & 27.1 & 50.2 & 1.9 & 27.7 & 43.8 & 1.6 & -0.3 \\
\hline Moldova & 27.4 & 39.7 & 1.4 & 27.2 & 12.9 & 0.5 & -1.0 \\
\hline Russia & 24.4 & 53.4 & 2.2 & 29.5 & 42 & 1.4 & -0.8 \\
\hline Ukraine & 25.3 & 40.3 & 1.6 & 31.4 & 29.3 & 0.9 & -0.7 \\
\hline Armenia & 35.9 & 31.6 & 0.9 & 37.5 & 11.5 & 0.3 & -0.6 \\
\hline Azerbaijan & 34 & 28.8 & 0.8 & 32.5 & 10 & 0.3 & -0.5 \\
\hline Georgia & 39.9 & 16.8 & 0.4 & 32 & 13.2 & 0.4 & 0.0 \\
\hline Kazakhstan & 32.5 & 43.6 & 1.3 & 37.9 & 24.1 & 0.6 & -0.7 \\
\hline Kyrgyzstan & 36.7 & 28.3 & 0.8 & 36.1 & 11.4 & 0.3 & -0.5 \\
\hline Tajikistan & 40.4 & 19.7 & 0.5 & 19.1 & 7.8 & 0.4 & -0.1 \\
\hline Turkmenistan & 41.7 & 25.1 & 0.6 & 21.9 & 5.5 & 0.3 & -0.4 \\
\hline Uzbekistan & 36.3 & 33.1 & 0.9 & 34.9 & 33.5 & 1.0 & 0.0 \\
\hline Northern Tier CEE & 22.6 & 52.8 & 2.8 & 38.0 & 51.0 & 1.6 & -1.3 \\
\hline Southern Tier CEE & 15.3 & 58.1 & 4.5 & 26.4 & 40.4 & 1.8 & -3.0 \\
\hline Eurasia & 33.5 & 34.2 & 1.1 & 30.6 & 20.4 & 0.7 & -0.4 \\
\hline
\end{tabular}

UNICEF, Social Monitor (2004). 
Figure 33

Basic Enrollment vs. PISA Results

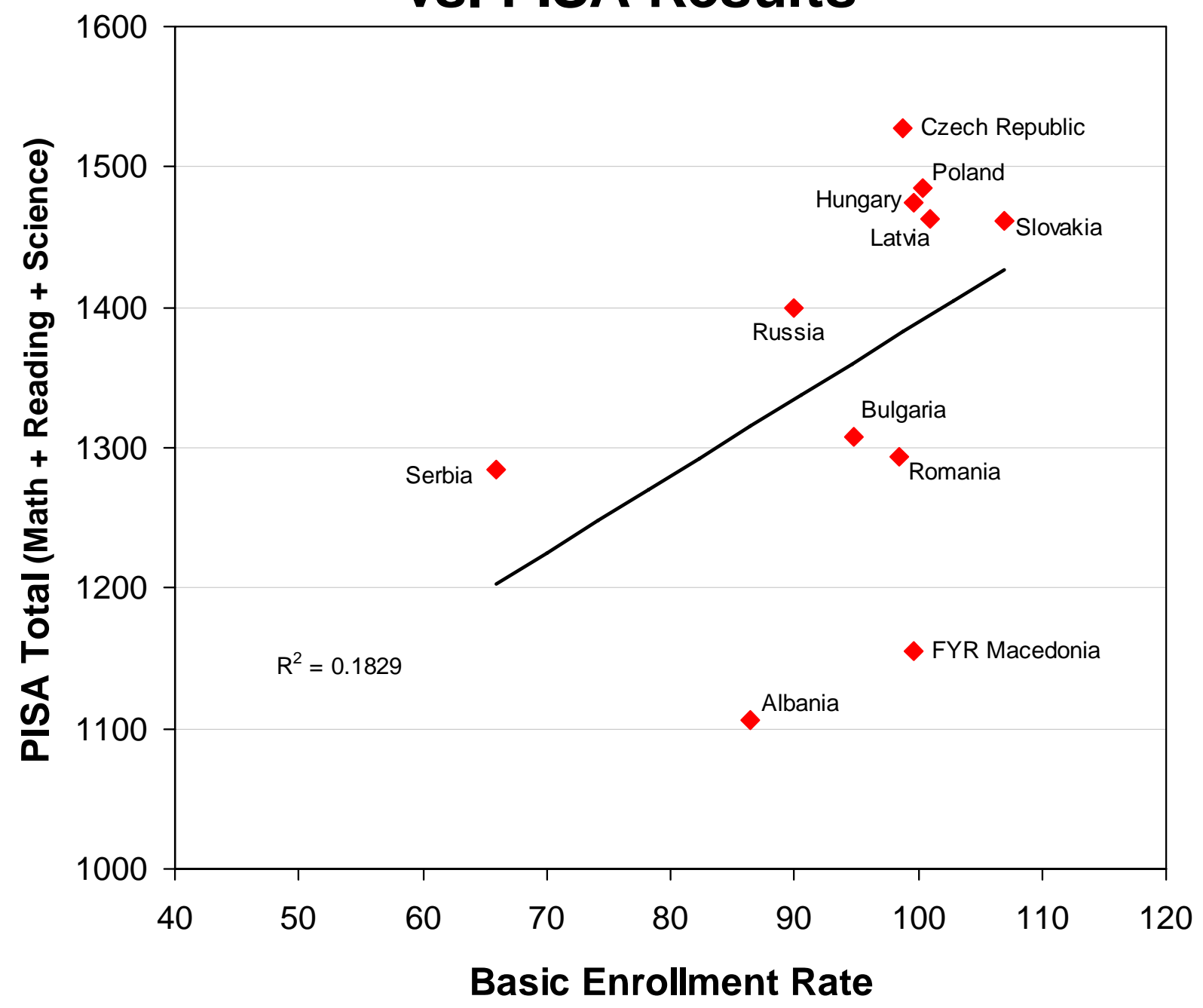

Northern Tier CEE countries, Serbia, and Russia use PISA 2003 results; Southern Tier CEE countries (except Serbia) use PISA 2000 (PLUS) results. Northern Tier CEE annd Russia use 2002 enrollment figures, Serbia uses 2001; Southern Tier CEE countries (except Serbia) use 2001 enrollment figures.

UNICEF, Social Monitor 2004 (2004). OECD, Learning for Tomorrow's World: First Results from PISA 2003 (2004). 
Figure 34

Total Secondary Enrollment vs. PISA Results

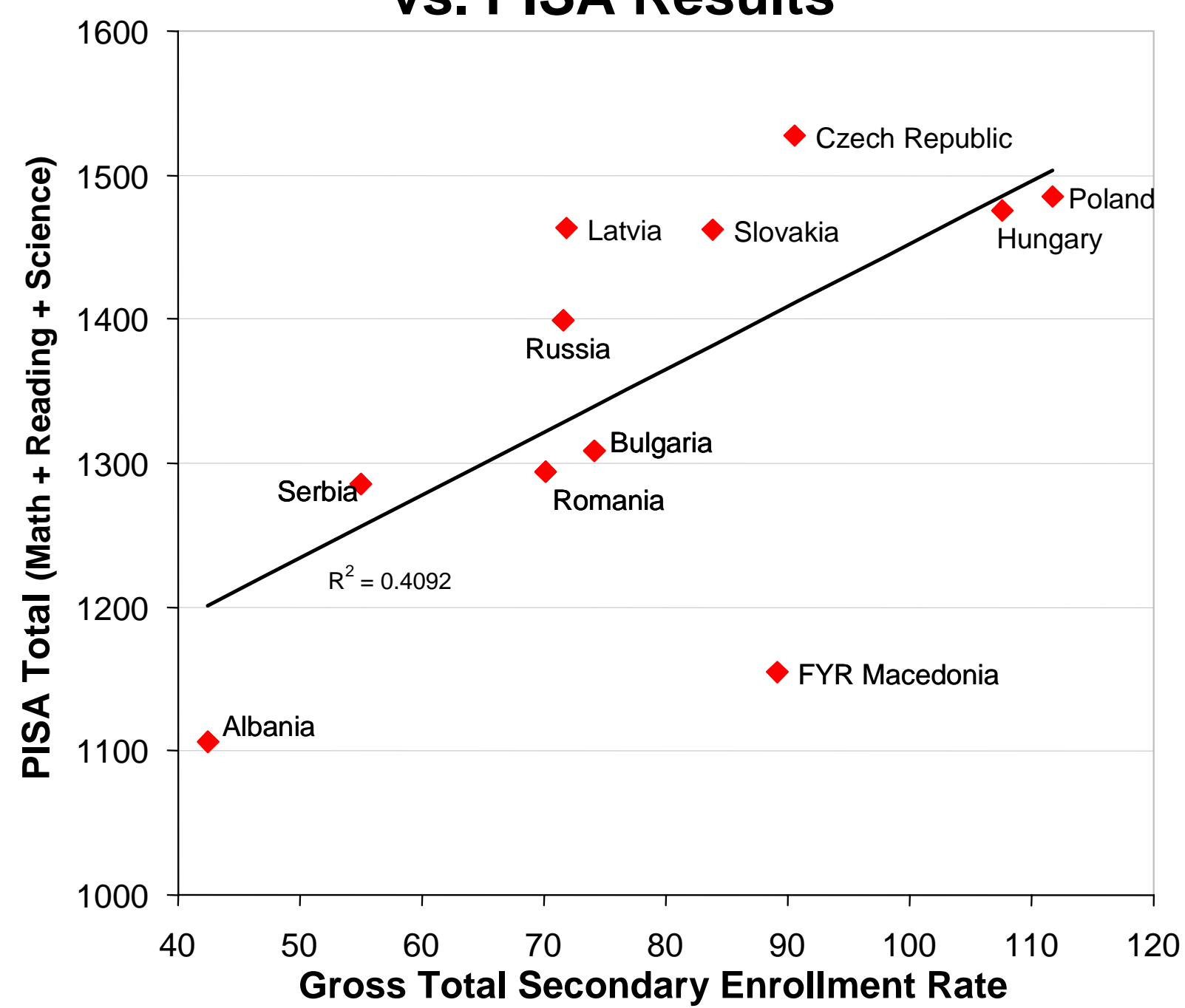

Northern Tier CEE countries, Serbia, and Russia use PISA 2003 results; Southern Tier CEE countries (except Serbia) use PISA 2000 (PLUS) results. Northern Tier CEE and Russia use 2002 enrollment figures; Southern Tier CEE countries use 2001 enrollment figures.

UNICEF, Social Monitor 2004 (2004). OECD, Learning for Tomorrow's World: First Results from PISA 2003 (2004). 
Figure 35

General Secondary Enrollment vs. PISA Results

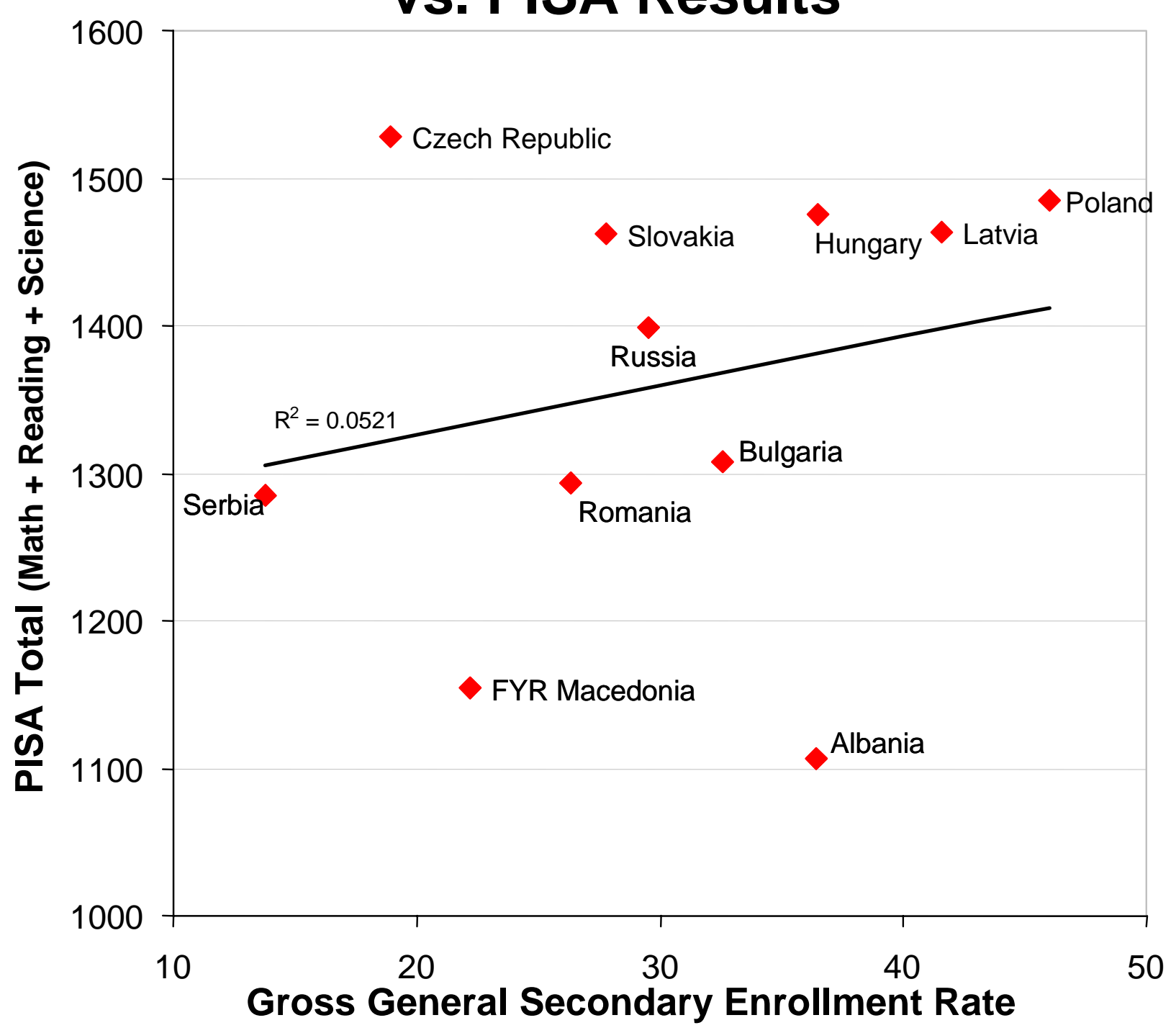

Northern Tier CEE countries, Serbia, and Russia use PISA 2003 results; Southern Tier CEE countries (except Serbia) use PISA 2000 (PLUS) results. Northern Tier CEE and Russia use 2002 enrollment figures; Southern Tier CEE countries use 2001 enrollment figures.

UNICEF, Social Monitor 2004 (2004). OECD, Learning for Tomorrow's World: First Results from PISA 2003 (2004). 
Figure 36

\section{Vocational/Technical Enrollment} vs. PISA Results

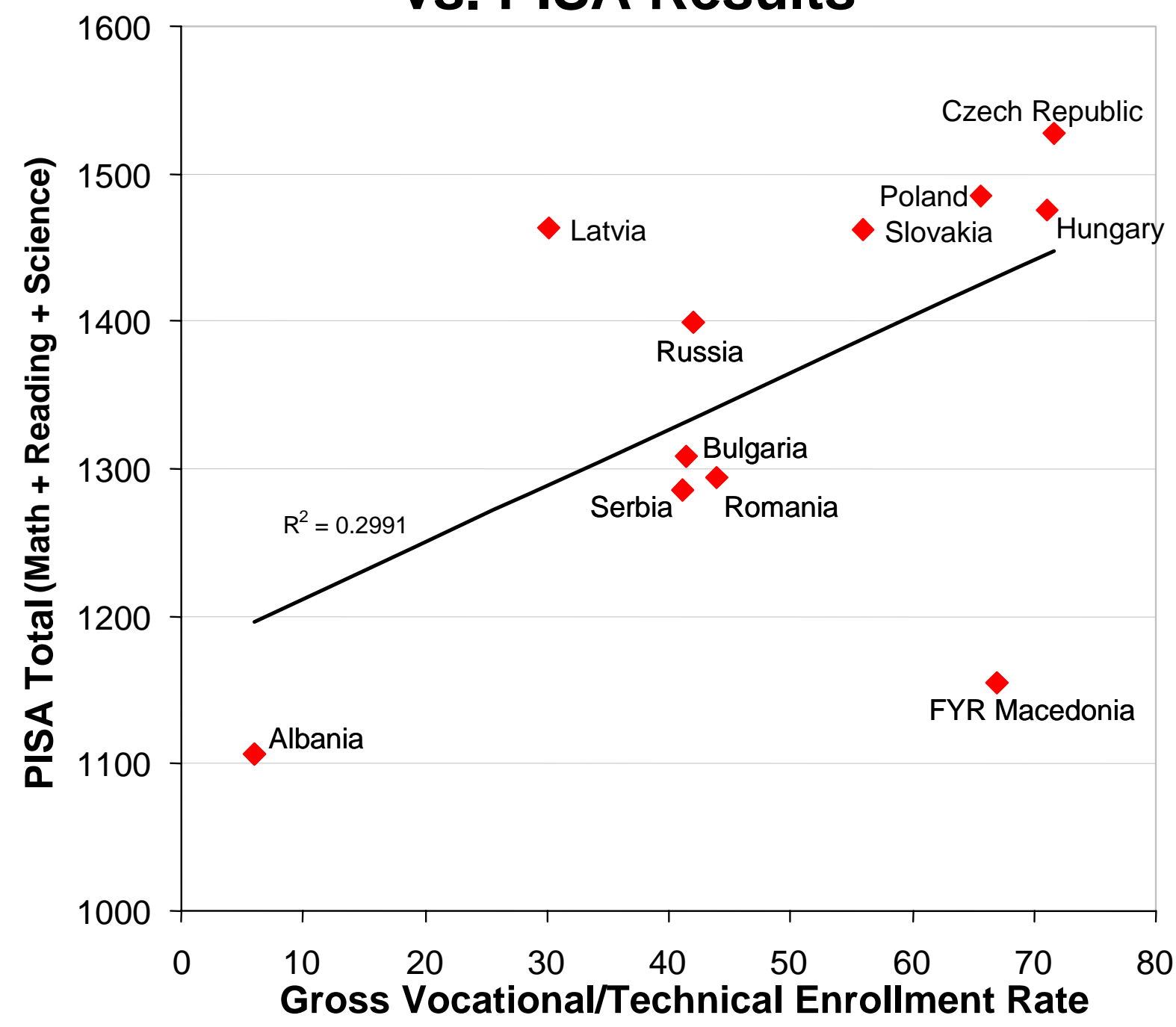

Northern Tier CEE countries, Serbia, and Russia use PISA 2003 results; Southern Tier CEE countries (except Serbia) use PISA 2000 (PLUS) results. Northern Tier CEE and Russia use 2002 enrollment figures, Southern Tier CEE countries use 2001 enrollment figures.

UNICEF, Social Monitor 2004 (2004). OECD, Learning for Tomorrow's World: First Results from PISA 2003 (2004). 
Figure 37

Higher Education Enrollment vs. PISA Results

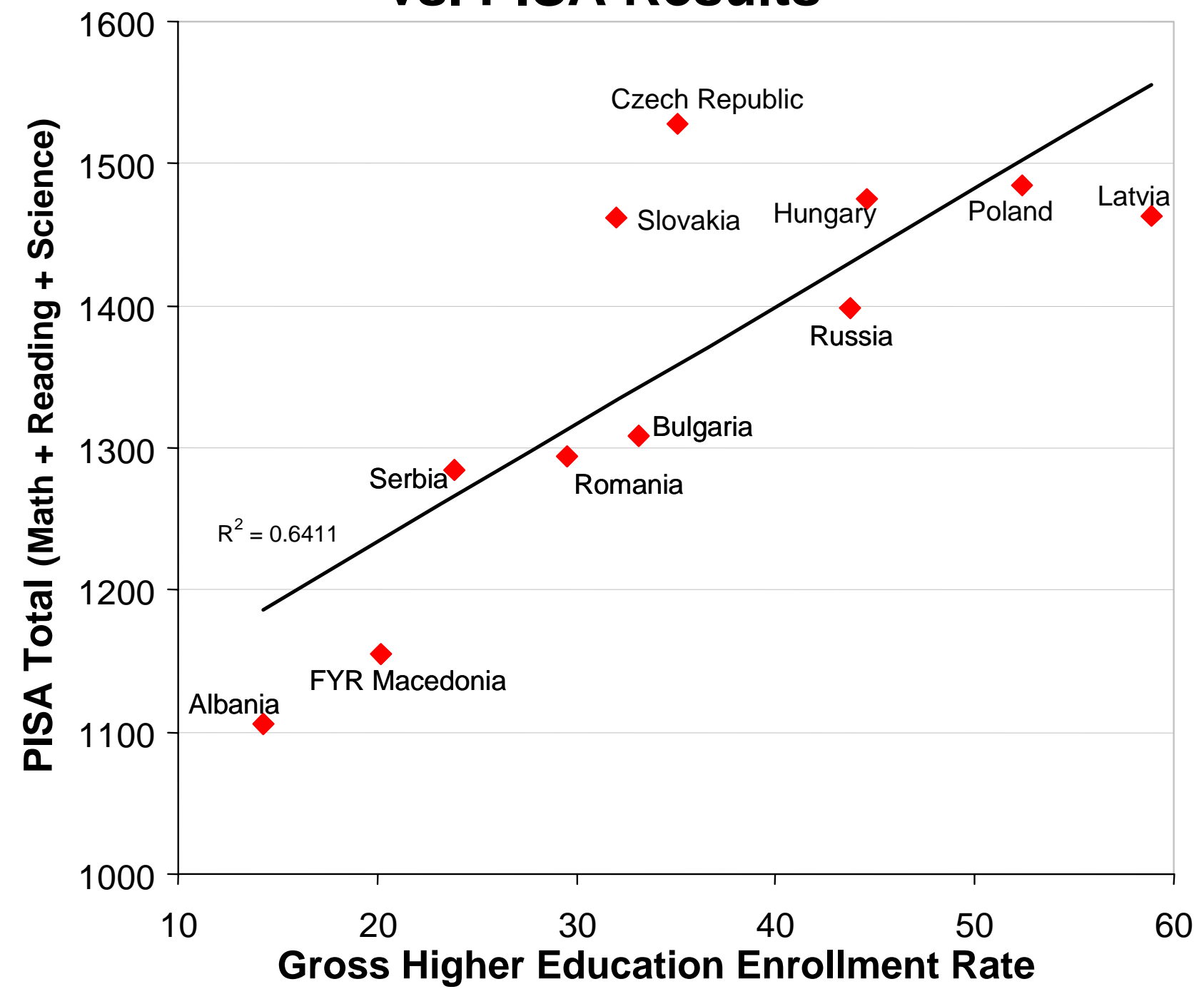

Northern Tier CEE countries, Serbia, and Russia use PISA 2003 results; Southern Tier CEE countries (except Serbia) use PISA 2000 (PLUS) results. Northern Tier CEE and Russia use 2002 enrollment figures; Southern Tier CEE countries use 2001 enrollment figures.

UNICEF, Social Monitor 2004 (2004). OECD, Learning for Tomorrow's World: First Results from PISA 2003 (2004). 
Figure 38

Education Spending

vs. PISA Results

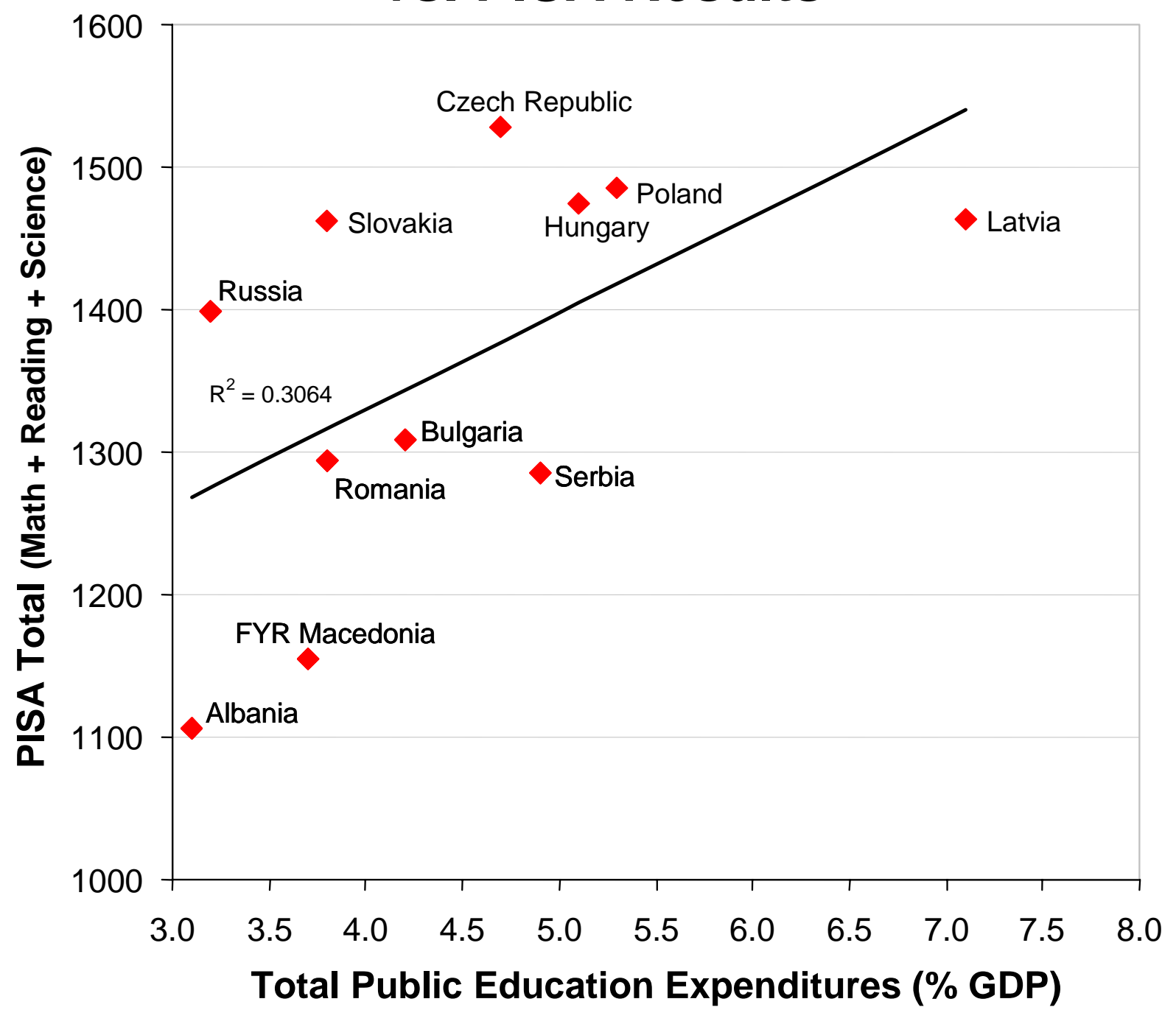

Northern Tier CEE countries, Serbia, and Russia use PISA 2003 results; Southern Tier CEE countries (except Serbia) use PISA 2000 (PLUS) results. Czech Republic, Hungary, Latvia, and Poland use 2002 expenditure figures; Serbia and Russia use 2000; Albania, Bulgaria, and FYR Macedonia use 1999..

UNICEF, Social Monitor 2004 (2004). OECD, Learning for Tomorrow's World: First Results from PISA 2003 (2004). 
Figure 39

Education Spending

vS. PISA Results

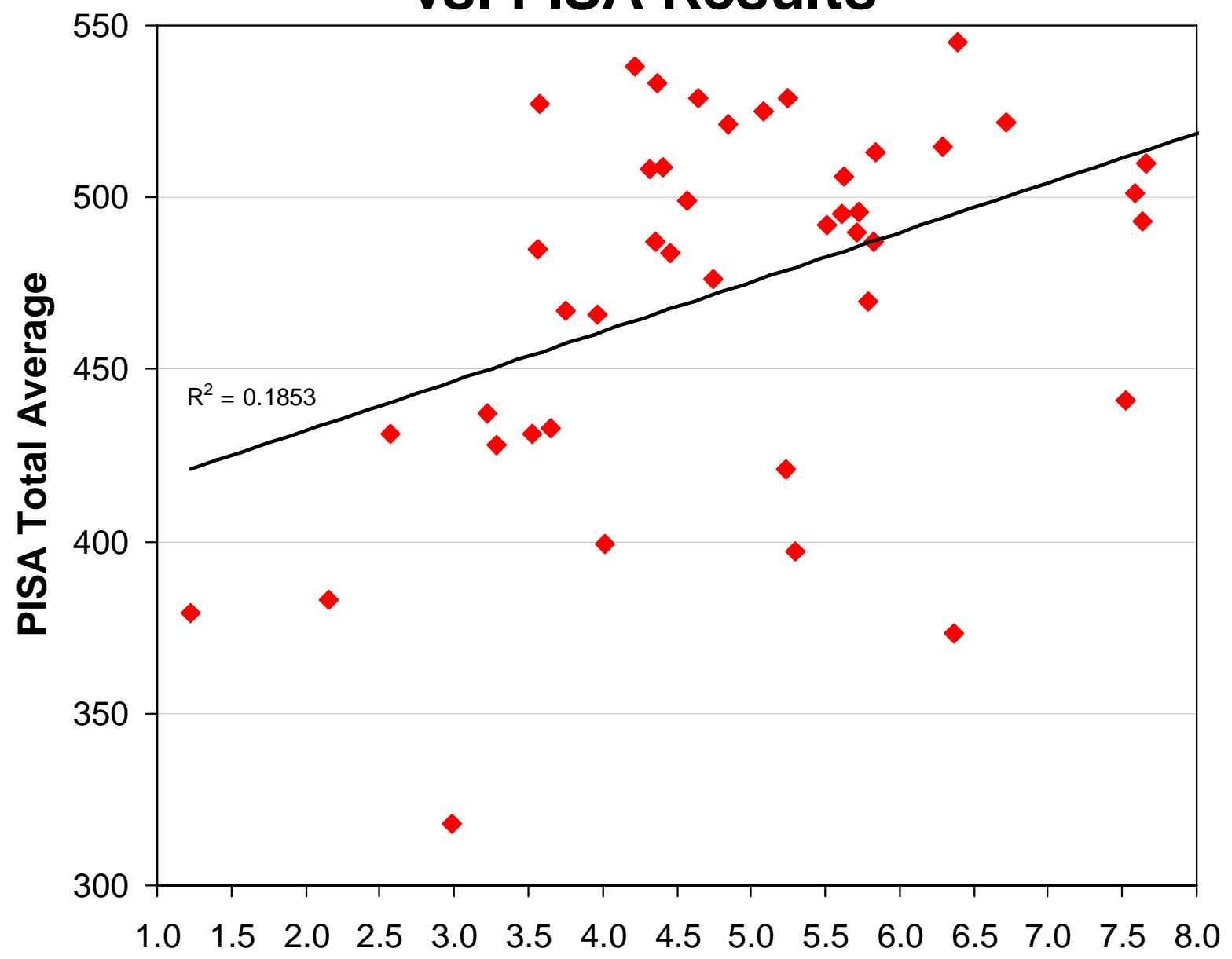

Total Public Education Expenditures (\% GDP)

Bulgaria, Peru, Romania, and the United Kingdom use PISA 2000 results; all other countries use PISA 2000. OECD, Learning for Tomorrow's World: First Results from PISA 2003 (2004). Enrollment figures used from closest year available to PISA assessment. Data taken from UNESCO Institute for Statistics, 2005. 
Table 16: R\&D Personnel per Million Inhabitants

\begin{tabular}{|c|c|c|c|}
\hline & $1994-96$ & 1999-01 & $\%$ Change \\
\hline Croatia & 2,674 & 1,534 & -43 \\
\hline Georgia & 3,857 & 2,514 & -35 \\
\hline Bulgaria & 2,460 & 1,639 & -33 \\
\hline Ukraine & 3,886 & 2,712 & -30 \\
\hline Romania & 1,961 & 1,458 & -26 \\
\hline Belarus & 2,647 & 2,153 & -19 \\
\hline Kyrgyzstan & 772 & 630 & -18 \\
\hline Slovenia & 3,678 & 3,135 & -15 \\
\hline Latvia & 1,579 & 1,376 & -13 \\
\hline Armenia & 1,731 & 1,536 & -11 \\
\hline Moldova & 1,763 & 1,597 & -9 \\
\hline Estonia & 2,488 & 2,334 & -6 \\
\hline Russia & 4,208 & 4,045 & -4 \\
\hline Slovakia & 2,586 & 2,633 & 2 \\
\hline Lithuania & 2,719 & 2,795 & 3 \\
\hline Poland & 1,299 & 1,473 & 13 \\
\hline Czech Republic & 1,854 & 2,178 & 17 \\
\hline Hungary & 1,545 & 1,950 & 26 \\
\hline Europe and Eurasia & 3,230 & 2,346 & -27 \\
\hline NT CEE & 1,670 & 1,842 & 10 \\
\hline ST CEE & 2,171 & 965 & -56 \\
\hline Eurasia & 3,905 & 2,746 & -30 \\
\hline \multicolumn{4}{|l|}{ Muslim Majority } \\
\hline \multicolumn{4}{|l|}{ Balkans } \\
\hline Caucasus & 3,042 & 1,096 & -64 \\
\hline E\&E less Balkans\&Caucasus & 3243 & 2515 & -22 \\
\hline Congo & 100 & 70 & -30 \\
\hline Mongolia & 708 & 647 & -9 \\
\hline Panama & 317 & 308 & -3 \\
\hline Zambia & 56 & 55 & -2 \\
\hline Germany & 4,155 & 4,457 & 7 \\
\hline Mexico & 366 & 408 & 11 \\
\hline China & 459 & 584 & 27 \\
\hline Uganda & 34 & 38 & 12 \\
\hline El Salvador & 15 & 47 & 213 \\
\hline EU-15 (4 countries) & 2,732 & 3,488 & 32 \\
\hline Latin America \& Caribbean (10 countries) & 1,626 & 749 & -54 \\
\hline East Asia \& Oceania (5 countries) & 870 & 1,506 & 73 \\
\hline
\end{tabular}

UNESCO Institute for Statistics (1997 and 2004).

1/ 1996 for Lithuania, Mexico, Tunisia, Uganda, Congo, Zambia, Mongolia, Germany and 1994 for Romania, Kyrgyzstan and Madagascar.

2/ 1997 for Kyrgyzstan; 1999 for Croatia, Latvia, Georgia, Zambia, Germany and Mexico 2000 for Bulgaria, Estonia, Moldova, Ukraine, Armenia, Congo, Mongolia and Uganda. 
R\&D Personnel in E\&E

Figure 40

1994-96 vs. $1999-01$

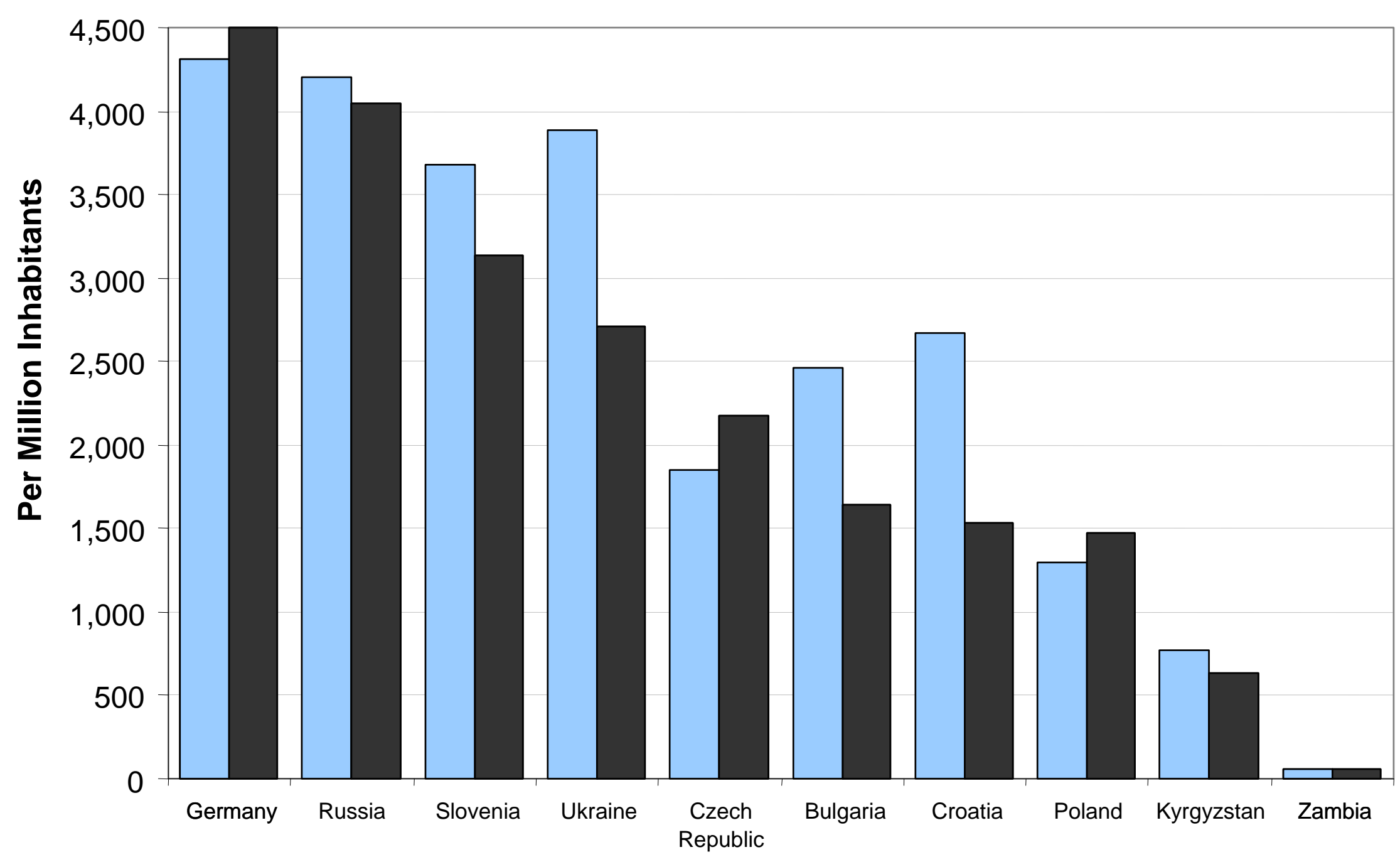

$1994-96$

$1999-2001$

UNESCO Institute for Statistics (1997 and 2004). 


\begin{tabular}{|c|c|c|c|c|c|}
\hline \multicolumn{6}{|c|}{ Table 17. Education Gaps } \\
\hline \multirow{3}{*}{$\begin{array}{l}\text { Czech Republic } \\
\text { Estonia }\end{array}$} & $\begin{array}{l}\text { Education } \\
\text { Spending } \\
02 \text { or mrd }\end{array}$ & $\begin{array}{c}\text { Primary } \\
\text { Enrollment } \\
02 \text { or mrd }\end{array}$ & $\begin{array}{c}\text { Pre-primary } \\
\text { Enrollment } \\
02 \text { or mrd }\end{array}$ & $\begin{array}{c}\text { Total } \\
\text { Secondary } \\
\text { Enrollment } \\
02 \text { or mrd }\end{array}$ & $\begin{array}{c}\text { Tertiary } \\
\text { Enrollment } \\
02 \text { or mrd }\end{array}$ \\
\hline & 4.7 & 98.7 & 88.1 & 90.6 & 35.1 \\
\hline & 6.8 & 104.4 & 80.5 & 79.7 & 53.2 \\
\hline Lithuania & 6.3 & 103 & 54.5 & 66.7 & 56.5 \\
\hline Slovakia & 3.8 & 107 & 70.7 & 83.8 & 32 \\
\hline Poland & 5.3 & 100.3 & 51.1 & 111.8 & 52.4 \\
\hline Hungary & 5.1 & 99.6 & 87.8 & 107.6 & 44.6 \\
\hline Belarus & 6.8 & 93.3 & 69.2 & 71.6 & 34.3 \\
\hline Ukraine & 5.6 & 94.7 & 48.7 & 60.8 & 38.7 \\
\hline Latvia & 7.1 & 101 & 77.7 & 71.8 & 58.9 \\
\hline Russia & 3.2 & 90 & 68.2 & 71.5 & 43.7 \\
\hline Croatia & NA & 95.7 & 38.4 & 83.1 & 31.5 \\
\hline Slovenia & 5.1 & 101.1 & 64.2 & 100.5 & 69.3 \\
\hline Moldova & 5.8 & 94.7 & 52.4 & $\star 40.1$ & * 24.1 \\
\hline Kazakhstan & NA & 100 & *13.5 & 62 & 38 \\
\hline Serbia \& Mont & 4.9 & $\star * 65.9$ & 44.6 & 76 & *23.9 \\
\hline Bulgaria & 4.2 & 98.7 & 74.2 & 85.5 & 33.9 \\
\hline Kyrgyzstan & 4.5 & 94.8 & $\star 9.5$ & * 47.5 & 35 \\
\hline Georgia & $\star 2.2$ & 97 & 30.8 & $\star 45.2$ & 38.4 \\
\hline Uzbekistan & NA & 97.5 & *19.9 & 68.4 & $\star 7.9$ \\
\hline Romania & $\star 2.9$ & 100.9 & 71 & 73.6 & 32.5 \\
\hline Macedonia & 3.7 & 97.1 & 27.1 & 62.8 & $\star 22.5$ \\
\hline Azerbaijan & 3.2 & 90.4 & *19.3 & *42.5 & *13.5 \\
\hline Armenia & *1.9 & 88.4 & $\star 25.7$ & *49.1 & $\star 21.8$ \\
\hline Albania & $\star 2.6$ & 104 & 34.3 & *48.9 & *14.3 \\
\hline Bosnia \& Herz & NA & *79.3 & $\star 8.9$ & $73 ?$ & *19.2 \\
\hline Tajikistan & $\star 2.6$ & 94.4 & *6.1 & $\star 26.9$ & *13 \\
\hline Turkmenistan & 5.8 & $\star 80.8$ & $\star 20.2$ & $\star 27.4$ & $\star 2.6$ \\
\hline & $\star<3 \%$ & * <85\% & $\star<30 \%$ & * $<50 \%$ & $*<25 \%$ \\
\hline
\end{tabular}

Data not available: NA; Vulnerable: *) 


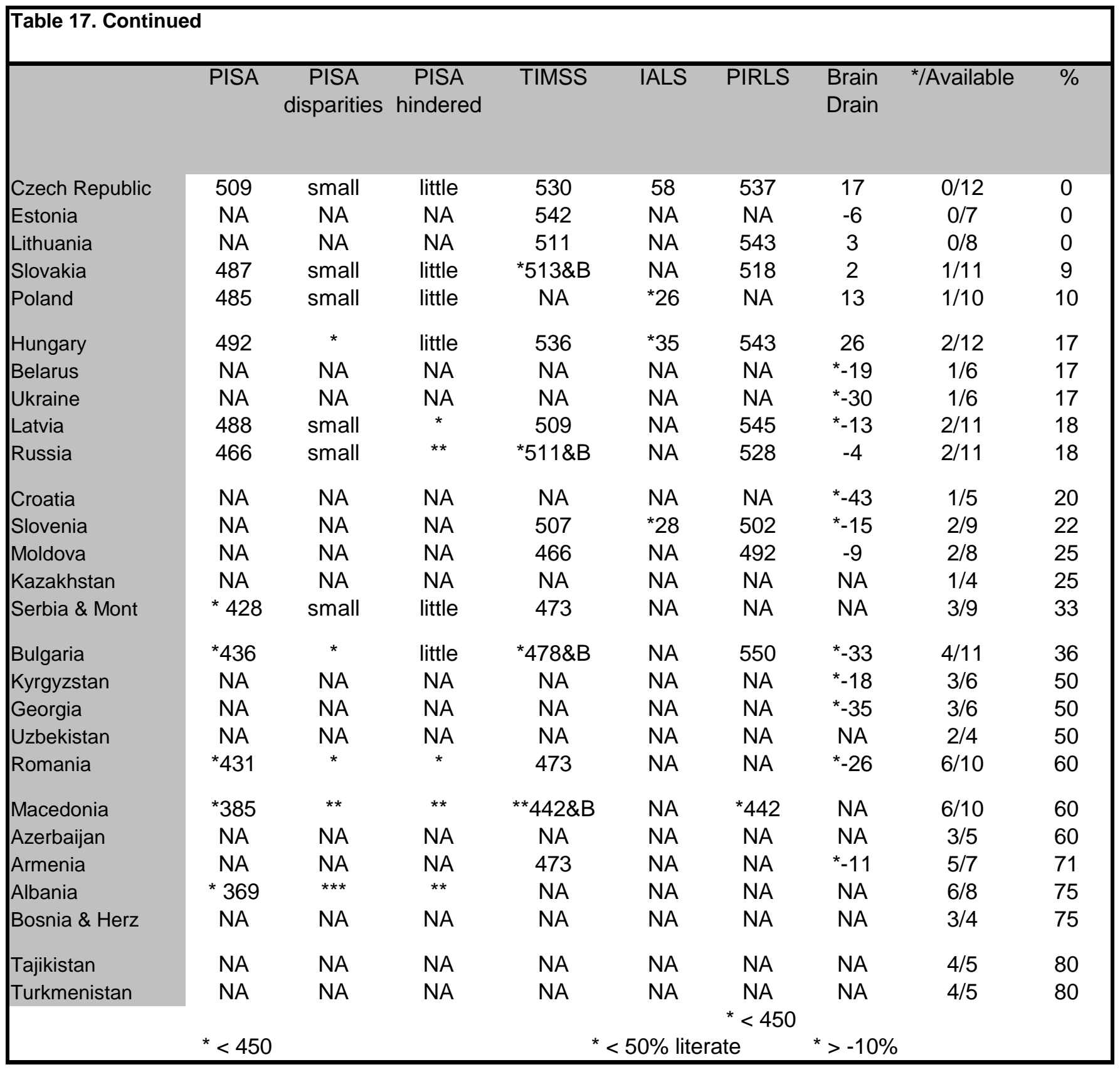

B: Backsliding

PISA disparities: by subject; gender; region

(subject: * => 7.5\%; gender: * > 5\%; region: * > 10\%)

PISA hindered: by heating, etc.; instructional materials

(heating: * > 25\%; instructional mat: * $>35 \%$ )

TIMSS: level and/or trend

(level: * < 450; trend: backsliding since 1995)

Brain drain: change in R\&D persons from 1994 to 2001

( ${ }^{*}>10 \%$ decrease) 
Figure 41

\section{Enrollments in FYR Macedonia}

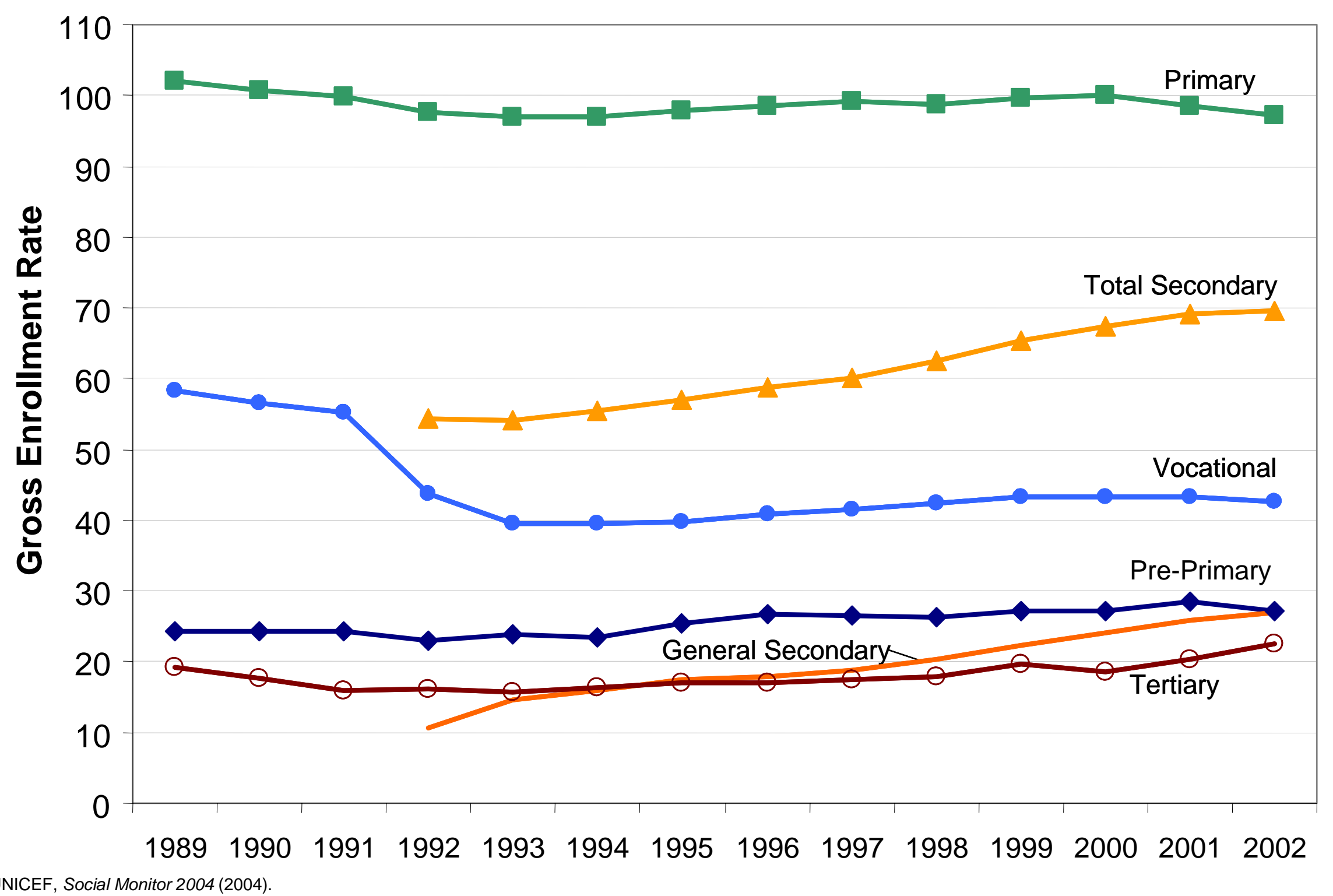


Figure 42

\section{PISA Results for FYR Macedonia}

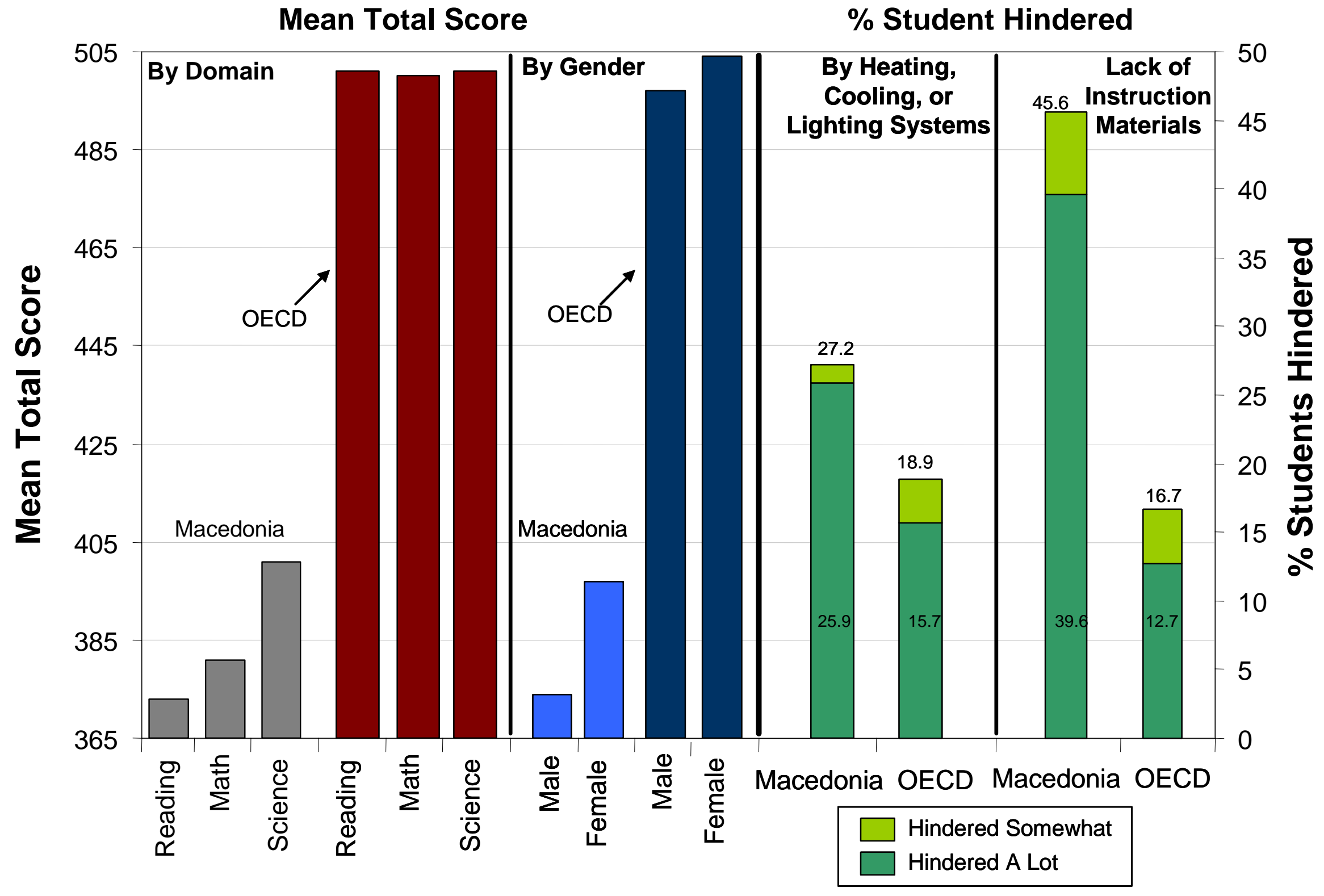


Figure 43

\section{Enrollments in Albania}

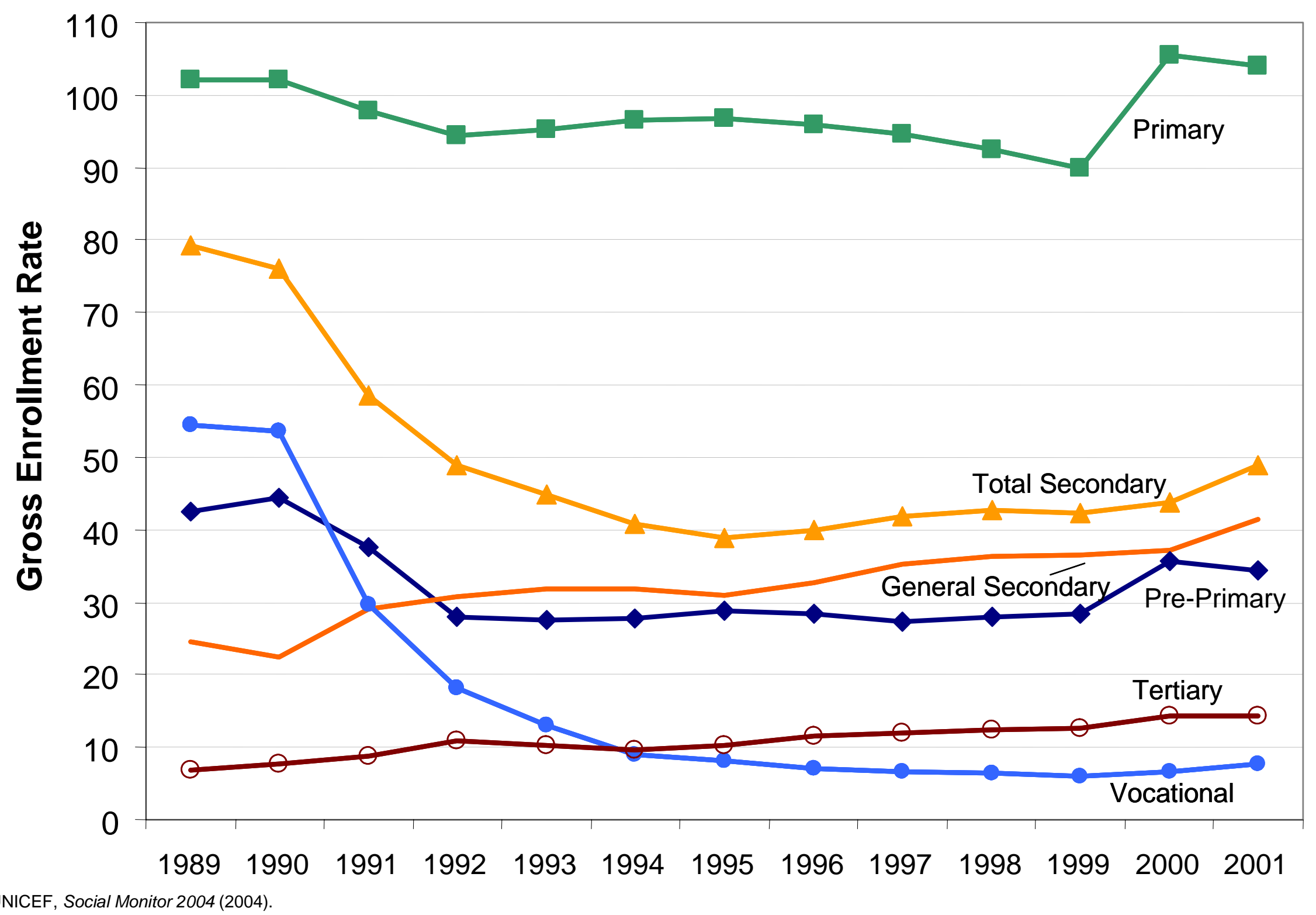


Figure 44

\section{PISA Results for Albania}

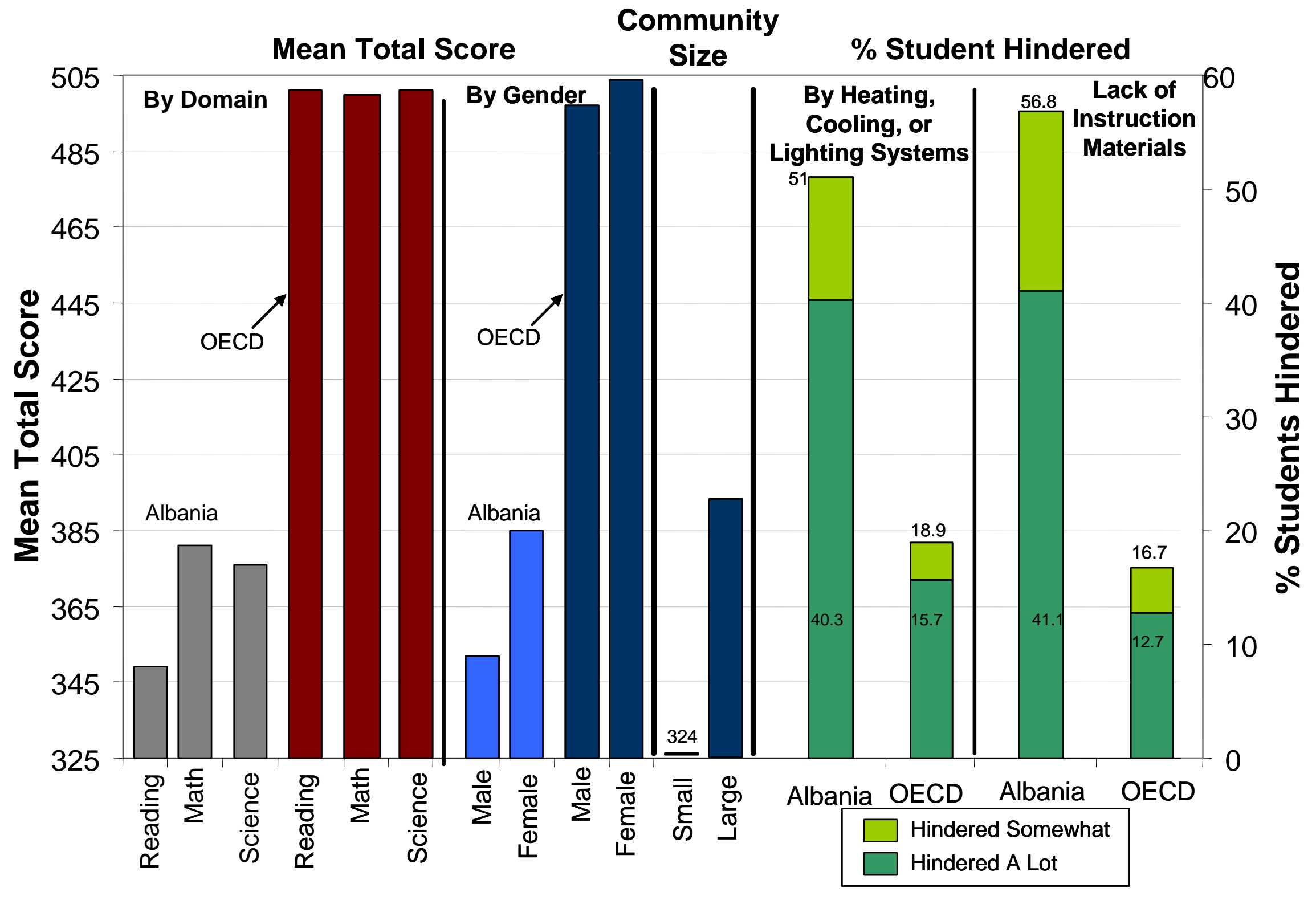




\section{References}

Berryman, Sue, Rasnake, Roger, Allison, Christine. (2002) Education Systems of Europe and Eurasia: Strategic Investment Options for USAID. Aguirre International and the International Science and Technology Institute.

Brown, Giorgina, Micklewright, John, Schnepf, Sylke, Waldmann, Robert. (2005) Cross National Surveys of Learning Achievement: How Robust are the Findings? ISTAT, Rome.

Micklewright, John. (2000) Education, Inequality, and Transition. UNICEF Innocenti Research Centre, Florence.

Mullis, I.V.S., M.O. Martin, E.J. Gonzalez, Kennedy, Ann (2004), PIRLS 2001 International Report: IEA's Study of Reading Literacy Achievement in Primary School in 35 Countries, International Study Center, Lynch School of Education, Boston, College: Chestnut Hill, MA.

Mullis, I.V.S., M.O. Martin, E.J. Gonzalez, S.J. Chrostowski (2004), TIMSS 2003 International Science Report: Findings from IEA's Trends in International Mathematics and Science Study at the Fourth and Eight Grades, International Study Center, Lynch School of Education, Boston, College: Chestnut Hill, MA.

OECD (2004), Learning for Tomorrow's World: First Results from PISA 2003, Organization for Economic Development and Cooperation: Paris.

OECD and Statistics Canada, Literacy in the Information Age: Final Report of the International Adult Literacy Survey. Ottawa, Ontario: Statistics Canada, 2000.

OECD and UNESCO (2003), Literacy Skills for the World of Tomorrow: Further Results from PISA 2000, Organization for Economic Development and UNESCO Institute for Statistics.

UNICEF, Innocenti Social Monitor 2004, Florence: UNICEF Innocente Research Center, 2004. Statistical Annex.

USAID/EE/DGST. Social Transition Strategy. Bureau for Europe and Eurasia, 2005.

USAID/EE/DGST. Social Issues Critical for Sustainability of Reform: Education Sector Discussion Paper (August 2003).

US Department of Education. Comparing NAEP, TIMSS, and PISA in Mathematics and Science (2004). 